Andrews University

Digital Commons @ Andrews University

1999

\title{
Gustavo Gutierrez's Understanding of the Kingdom of God in the Light of the Second Vatican Council
}

Victor Figueroa-Villarreal

Andrews University

Follow this and additional works at: https://digitalcommons.andrews.edu/dissertations

Part of the Catholic Studies Commons, History Commons, and the Religious Thought, Theology and Philosophy of Religion Commons

\section{Recommended Citation}

Figueroa-Villarreal, Victor, "Gustavo Gutierrez's Understanding of the Kingdom of God in the Light of the Second Vatican Council" (1999). Dissertations. 49.

https://digitalcommons.andrews.edu/dissertations/49

https://dx.doi.org/10.32597/dissertations/49

This Dissertation is brought to you for free and open access by the Graduate Research at Digital Commons @ Andrews University. It has been accepted for inclusion in Dissertations by an authorized administrator of Digital Commons@ Andrews University. For more information, please contact repository@andrews.edu. 


\section{Andrews \$university}

Seek Knowledge. Affirm Faith. Change the World.

Thank you for your interest in the

\section{Andrews University Digital Library of Dissertations and Theses.}

Please honor the copyright of this document by not duplicating or distributing additional copies in any form without the author's express written permission. Thanks for your cooperation. 


\section{INFORMATION TO USERS}

This manuscript has been reproduced from the microfilm master. UMI films the text directly from the original or copy submitted. Thus, some thesis and dissertation copies are in typewriter face, while others may be from any type of computer printer.

The quality of this reproduction is dependent upon the quality of the copy submitted. Broken or indistinct print, colored or poor quality illustrations and photographs, print bleedthrough, substandard margins, and improper alignment can adversely affect reproduction.

In the unlikely event that the author did not send UMI a complete manuscript and there are missing pages, these will be noted. Also, if unauthorized copyright material had to be removed, a note will indicate the deletion.

Oversize materials (e.g., maps, drawings, charts) are reproduced by sectioning the original, beginning at the upper left-hand comer and continuing from left to right in equal sections with small overlaps.

Photographs included in the original manuscript have been reproduced xerographically in this copy. Higher quality $6^{\circ} \times 9^{*}$ black and white photographic prints are available for any photographs or illustrations appearing in this copy for an additional charge. Contact UMI directly to order.

Bell \& Howell Information and Leaming 300 North Zeeb Road, Ann Arbor, MI 48106-1346 USA 800-521-0600

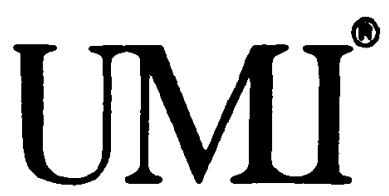




\title{
NOTE TO USERS
}

\section{This reproduction is the best copy available.}

\author{
UMI
}




\author{
Andrews University \\ Seventh-day Adventist Theological Seminary
}

\begin{abstract}
GUSTAVO GUTIÉRREZ'S UNDERSTANDING OF THE KINGDOM OF GOD IN THE LIGHT OF THE SECOND VATICAN COUNCIL
\end{abstract}

\author{
A Dissertation \\ Presented in Partial Fulfillment \\ of ine Requirements for the Degree \\ Doctor of Philosophy
}

by

VÉcor Eigueroa-Villarreal

November 1999 
UMI Number: 9979889

Copyright 2000 by

Figueroa-Villarreal, Victor

All rights reserved.

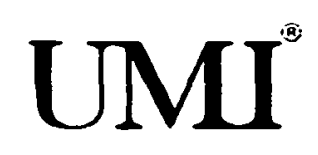

UMI Microform 9979889

Copyright 2000 by Bell \& Howell Information and Learning Company.

All rights reserved. This microform edition is protected against unauthorized copying under Title 17, United States Code.

Bell \& Howell Information and Learning Company

300 North Zeeb Road

P.O. Box 1346

Ann Arbor, MI 48106-1346 
e Copyright by Victor Figueroa 2000

All Rights Reserved

Reproduced with permission of the copyright owner. Further reproduction prohibited without permission. 


\title{
GUSTAVO GUTIERREZ'S UNDERSTANDING OF THE KINGDOM OF GOD IN THE LIGHT OF THE SECOND VATICAN COUNCIL
}

\author{
A dissertation \\ presented in partial fulfillment \\ of the requirements for the degree \\ Doctor of Philosophy
}

by

Victor Figueroa-Villarreal

APPRQVAL BY THE COMMITTEE:

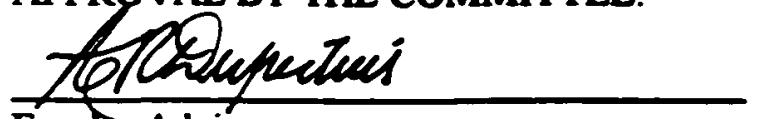

Faculty dviser,

Atilio R. Dupertuis

Professor of Theology

Climapan H. A.P

Miroslav M. Kis

Professor of Ethics

Zcoul solum

Raoul Dederen

Profegsor of Theology, Emeritus

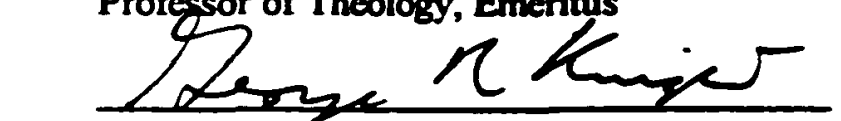

George R. Knight

Professpr of Church History

Q. hule.

Ostatdo E. Mottesi, Professor of Retigion and Society

Northern Baptist Theological Seminary

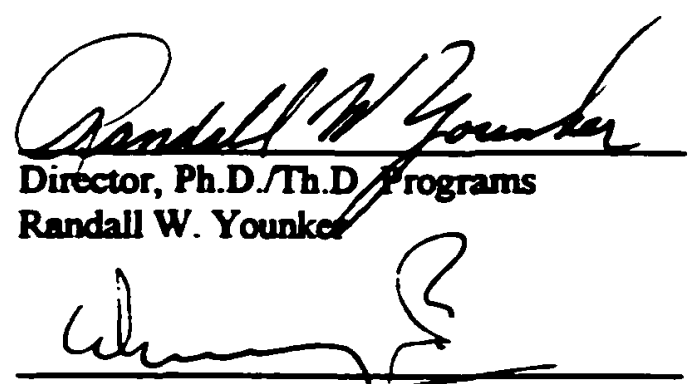

Dean, SDATheotogto Seminary Werner K. Vytumeistet 
ABSTRACT

\title{
GUSTAVO GUTIÉRREZ'S UNDERSTANDING OF \\ THE KINGDOM OF GOD IN THE LIGHT OF THE SECOND VATICAN COUNCIL
}

\author{
by \\ Victor Figueroa-Villarreal
}

Adviser: Atilio R. Dupertuis 


\title{
ABSTRACT OF GRADUATE STUDENT RESEARCH \\ Dissertation
}

\author{
Andrews University \\ Seventh-day Adventist Theological Seminary
}

\begin{abstract}
Title: GUSTAVO GUTIÉRREZ'S UNDERSTANDING OF THE KINGDOM OF GOD IN THE LIGHT OF THE SECOND VATICAN COUNCIL

Name of researcher: Víctor Figueroa-Villarreal

Name and degree of faculty chair: Atilio R. Dupertuis, Th.D. Date completed: November 1999
\end{abstract}

The proclamation of the Kingdom of God has been reformulated in every age and interpreted accordingly with regard to time and place. Traditionally within Roman Catholicism the Kingdom of God was identified with the church. This view produced a triumphalist attitude within the Roman Catholic Church. The Second Vatican Council brought a new attitude of openness toward the modern world, and with it the council opened the door for Roman Catholic liberation theologians to look for new ways to find what they regarded as the just solutions to the problems of Iatin America . 
The purpose of this research is to examine Gustavo Gutiérrez's understanding of the Kingdom of God in the light of Vatican II's teachings. To attain this goal the study undertakes three tasks. First, it describes his understanding of the Kingdom. Second, it analyzes it. Third, it evaluates his understanding against the background of the Roman Catholic position as set forth in the documents of the second Vatican council.

After a general overview of the historical and theological development of thought about God's Kingdom within Roman Catholicism, the dissertation focuses on the post-Vatican II developments in Latin American Roman Catholicism. It also investigates Gustavo Gutiérrez as theologian--his life, methodology, and hermeneutics.

Then this study describes and analyzes Gutiérrez's view of the Kingdom of God, and the particular trends that may have influenced him, both regarding content and methodology. Attention is given to the way his view of God's Kingdom functions in his theology. It also includes the concept of the Kingdom of God as portrayed in the documents of the second Vatican council.

Gutiérrez adds the meaning of liberation to the concept of the Kingdom of God. However, this concept loses much of its impact on modern Roman Catholic theology mainly because of its sociopolitical emphasis. Though social 
sciences can be a helpful tool for understanding the social condition in Latin America, they can never be the foundation of Christian faith and practice as suggested by Gutiérrez. Furthermore, Gutiérrez fails to acknowledge that the root of Latin American problems is to be found within human beings themselves. From their very birth, men and women, regardless their sociopolitical condition, have an innate predisposition to evil. One wonders, then, whether human beings in their sinful condition are able to build a less sinful society.

Finally, the dissertation evaluates Gutiérrez's understanding of the Kingdom in the light of Vatican II's teachings on the issue. The final conclusions are presented as well. 
TABLE OF CONTENTS

\section{LIST OF ABBREVIATIONS}

ACKNOWLEDGMENTS

Chapter

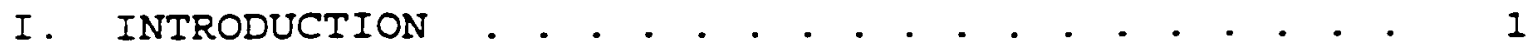

Gustavo Gutiérrez's Relevance in the Current

Debate on the Kingdom of God . . . . . . . 3

Statement and Justification of the Problem . 10

Review of Literature . . . . . . . . . . . 13

Purpose and Scope of the Study . . . . . . . . 17

Outine of the Study . . . . . . . . . . . . 17

II. HISTORICAI BACKGROUND

The Kingoiom of God in the Roman Catholic Church

Erom St. Augustine to Vatican II . . . . . 20

Protestant View on the Kingdom of God . . . . 37

Latin American Historical Context . . . . . . 43

Roman Catholicism and the Conquest of Latin

America . . . . . . . . . . . . . . 43 43

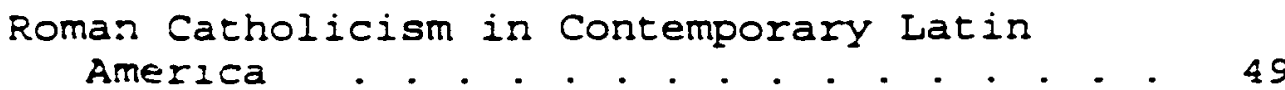

Gustavo Gutiérrez: The Theologian . . . . . . 57

Biographical Survey . . . . . . . . . . 57

Gutzézrez's Methodology and Hermeneutics. . 60

Summary . . . . . . . . . . . . . . 69

III. GUSTAVO GLZEKREZ'S UNDERSTANDING OF THE KINGDOM

OF GOD . . . . . . . . . . . . . . . . . . . 72

The Reiar:orstip between the kingdom of God and Temporal Reality . . . . . . . . . . . . 73

Salvasion and Liberation . . . . . . . . 78

The Kingiom of God and Salvation. . . . . . 83

The Language of the Kingdom of God . . . . . . 85

The Meaning of the kingdom of God . . . . . . . 91

$$
\text { iii }
$$


The Kingdom of God as Gift and Task . . . . . . 98 Historical and Eschatological Dimensions of the Kingdom of God . . . . . . . . . . . . . 106 Levels of Liberation. . . . . . . . . . . 108 Partial and Eschatological Realization of the Kingdom . . . . . . . . . . . . . . . . 113

The Kingdom and the Church . . . . . . . . . 119 Summary and Conclusion . . . . . . . . . . 125

IV. THE KINGDOM OF GOD IN THE DOCUMENTS OF THE SECOND VATICAN COUNCIL . . . . . . . . . . . . . 128

The Pre-conciliar Debate . . . . . . . . . 129

Vatican II and the Kingdom of God . . . . . . 139

The Kingdom and the Church . . . . . . . . 151

The Kingdom of God and the Church's Social

Doctrine . . . . . . . . . . . . . . . 157

Summary and Conclusion . . . . . . . . . . 178

V. SUMMARY AND CONCLUSION . . . . . . . . . . . . 180

Hermeneutical Considerations . . . . . . . 180

Gutiérrez's New Approach to Theology . . . . 185

Gutiérrez and the New Human Being . . . . 187

Gutiérrez and Social Sciences . . . . . . . 189

Vatican II, Gutiérrez, and the Kingdom of God . 198

Liberation-Salvation . . . . . . . . . . 199

Kingdom of God . . . . . . . . . . . . 202

The Kingdom of God and the Church . . . . 208

Conclusion . . . . . . . . . . . . . . . . . 211

BIBLIOGRAPHY . . . . . . . . . . . . . . . . . 220 


\section{LIST OF ABBREVIATIONS}

\begin{tabular}{|c|c|}
\hline Afer & African Ecclesiastical Review \\
\hline$A J T$ & Asia Journal of Theology \\
\hline$A m$ & America \\
\hline$A S$ & American Scholar \\
\hline$B Q$ & Baptist Quaterly \\
\hline Bol Teol & Boletín Teológico \\
\hline$C C$ & Christian Century \\
\hline $\mathrm{CH}$ & Church History \\
\hline Chmn & Churchman \\
\hline ChS & Church \& Society \\
\hline Chrcris & Christianity and Crisis \\
\hline ChrToday & Christianity Today \\
\hline Communio & Communio International Catholic Review \\
\hline Conc & Concilium \\
\hline Crs & Cristianismo y Sociedad \\
\hline Crosscur & Cross Currents \\
\hline Cuadernost & Cuadernos de Teología \\
\hline Cuestionest & Cuestiones Teológicas \\
\hline
\end{tabular}

v 


\begin{tabular}{|c|c|}
\hline CurTM & Currents in Theology and Mission \\
\hline$D G$ & Drew Gateway \\
\hline Dial & Dialog \\
\hline Ecum & The Ecumenist \\
\hline EstEcI & Estudios Eclesiásticos \\
\hline$E g T$ & Église et Théologie \\
\hline EstCent & Estudios Centroamericanos \\
\hline$E t h$ & Ethics \\
\hline EVRTh & Evangelical Review of Theology \\
\hline ExpTim & Expository Times \\
\hline Franc & Franciscanum \\
\hline Greg & Gregorianum \\
\hline$H D B$ & Harvard Divinity Bulletin \\
\hline HTR & Harvard Theological Review \\
\hline HeyJ & Heythrop Journal \\
\hline Horizons & $\begin{array}{l}\text { Horizons: The Journal of the College Theology } \\
\text { Society }\end{array}$ \\
\hline Int & Interpretation \\
\hline IntRMiss & International Review of Mission \\
\hline JChSt & Journal of Church and State \\
\hline JECSt & Journal of Ecumenical Studies \\
\hline JEvThS & $\begin{array}{l}\text { Journal of the Evangelical Theological } \\
\text { Society }\end{array}$ \\
\hline
\end{tabular}

$v i$ 


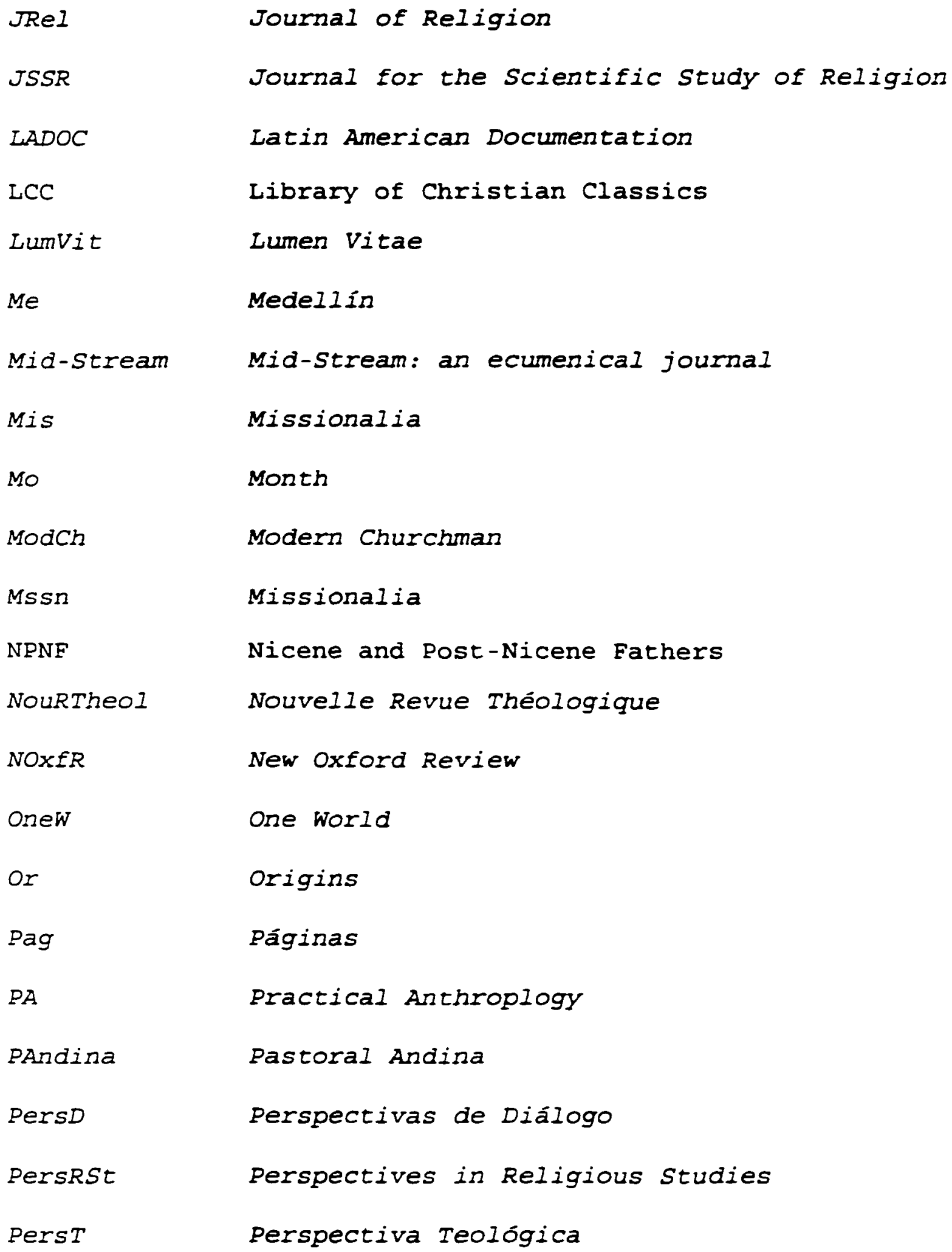




\begin{tabular}{|c|c|}
\hline PG & Patrologiae Cursus Completus, Series Graeca \\
\hline PL & Patrologiae Cursus Completus, Series Latina \\
\hline RBib & Revista Bíblica \\
\hline RefPW & Reformed and Presbyterian World \\
\hline$R L$ & Religion in Life \\
\hline ReISRev & Religious Studies Review \\
\hline RevExp & Review and Expositor \\
\hline RevP & Review of Politics \\
\hline RTL & Revista Teológica Limense \\
\hline ScriptaTh & Scripta Theologica \\
\hline$S J T$ & Scottish Journal of Theology \\
\hline Sing & Signos \\
\hline Soj & Sojourners \\
\hline StLukeJTh & St Luke's Journal of Theology \\
\hline SWJth & Southwestern Journal of Theology \\
\hline TAPS & $\begin{array}{l}\text { Transactions of the American Philosophical } \\
\text { Society }\end{array}$ \\
\hline$T D$ & Theology Digest \\
\hline Thisw & This world \\
\hline Thm & Themelios \\
\hline TN & Tierra Nueva \\
\hline Touch & Touchstone \\
\hline TS & Theological studies \\
\hline & viii \\
\hline
\end{tabular}


TSFBUI

TToday

Transf

$T X$

W

WorIdV

WW

ZMisSR
TSF Bulletin

Theology Today

Transformation

Theologica Xaveriana

Worship

Worldview

Word \& World

Zeitschrift für Missionswissenschaft und Religionswissenschaft

$i x$ 


\section{ACKNOWLEDGMENTS}

This dissertation could not have been written without the support and encouragement of my wife Inés, and my children Hans and Karen. I want to thank them for the sacrifices they made in giving me the time needed to complete this study, and for their constant prayers. I also wish to express my gratitude to the members of my committee: Dr. Atilio Dupertuis (chairman), Dr. Raoul Dederen, and Dr. Miroslav kis. They have patiently read and made opportune suggestions to improve the quality of this research. I deeply appreciate their insights and valuable criticism into the subject matter to enrich the text. Finally, I want to express my thanks to God from whom comes every good and perfect gift. 


\section{CHAPTER I}

\section{INTRODUCTION}

The Kingdom of God is a pivotal theme within the Christian tradition in general because it embraces the total message of the Bible, and conditions the attitude of the believer. Howard snyder states it this way: "What the people believe about the Kingdom often shapes what they do." = Karl Rahner, in a similar vein, declares that the concept of the kingdom of God has a critical function in church and society.

Scholars unanimously agree on the centrality of the

\section{John Bright, The Kingdom of God (Nashville, TN:}

Abingdon, 1953), 7. If it were necessary to select a title for the Bible, Bright's suggestion is "The Book of the Coming Kingdom of God," because "that is, indeed, its central theme everywhere" (ibid., 197). Likewise Wolfhart Pannenberg, Theology and the Kingdom of God (Philadelphia: Westminster, 1969), 53, argues that the notion of the Kingdom of God "must be recovered as a key to the whole of Christian theology"; it means that any theological study should have as its starting point this concept.

-Howard A. Snyder, Models of the Kingdom (Nashville: Abingdon, 1991), 12.

Karl Rahner and Herbert Vorgrimler, "Kingdom of God," Concise Theological Dictionary (1983), 265. 
Kingdom of God in Jesus' message.' This consensus does not necessarily mean that there is a clear understanding of what God's Kingdom is.: Scholars are at present divided on the

'The fact that the Kingdom of God dominates Jesus' preaching led Karl Rahner to remark that Jesus did not preach himself but God's Kingdom. Karl Rahner and Wilhelm Thüsing, A New Christology, trans. David Smith and Verdant Green (New York: Seabury Press, 1980), 90; see also pp. 910. Similarly, John Fuellenbach, The Kingdom of God: The Message of Jesus Today (Maryknoll, NY: Orbis, 1995), 4, observes that the theme of the Kingdom of God is not only predominant in Jesus" teaching, "it is also the content of his symbolic actions" such as his association with the outcast, his table fellowship with the tax-collectors and sinners and his acts of healing. Benedict $T$. Viviano, The Kingdom of God in History (Wilmington, DE: Michael Glazier, 1988), 9, on the other hand, calls attention to the fact that the Kingdom of God has been somehow ignored in Roman Catholic theology, spirituality, and liturgy. "When [it is] not ignored," Viviano notes, it is "often distorted beyond recognition." See also Rudolf Schnackenburg, God's Rule and Kingdom, trans. John Murray (New York: Herder and Herder, 1963), 9-10; Joseph Ratzinger, Eschatology: Death and Eternal Life, trans. Michael Waldstein (Washington, DC: Catholic University of America Press, 1988), 24-25; Stephen Benko, "The Kingdom of God in the Documents of Vatican II," in Gottesreich und Menschenreich, ed. Ernst Staehelin (Basel: Helbing \& Lichtenhahn, 1969), 571; Peter Hūnermann, "Reign of God," Encyclopedia of Theology: The Concise Sacramentum Mundi (1991), 1349. From a Protestant perspective see George $\mathrm{E}$. Ladd, A Theology of the New Testament (Grand Rapids, MI: Eerdmans, 1974), 57; Joachim Jeremias, New Testament Theology, trans. John Bowden (New York: Scribner, 1971), 96; Bright, The Kingdom of God, 17; Norman Perrin, Rediscovering the Teachings of Jesus (New York: Harper \& Row, 1967), 54; Herman Ridderbos, The Coming of the Kingdom, trans. $H$. de Jongste (Philadelphia, PA: Presbyterian and Reformed Pub., 1962), xi; Robert H. Stein, The Method and Message of Jesus' Teachings (Philadelphia, PA: Westminster, 1978), 60 .

-Snyder, Models of the Kingdom, 13. On the history of diverse interpretations of the Kingdom of God from the 
meaning of the Kingdom of God. As Jerald C. Brauer remarks, this concept is one of the most fruitful and yet controversial which has been used both to uphold the status quo and to promote social reforms.:

\section{Gustavo Gutiérrez's Relevance in the Current Debate on the Kingdom of God}

Traditional Roman Catholic theology understands the Kingdom as being spiritual in nature, = and, therefore, tends

Patristic period to modern times, see Ernst Staehelin, Die Verkündigung des Reiches Gottes in der Kirche Jesu Christi, 7 vols. (Basel: F. Reinhardt, 1951-65). An extensive contemporary work on this subject has been done by Norman Perrin, The Kingdom of God in the Teaching of Jesus (Philadelphia: Westminster, 1963); George E. Ladd, The Gospel of the Kingdom (Grand Rapids, MI: Eerdmans, 1959); idem, Crucial Questions about the Kingdom of God (Grand Rapids, MI: Eerdmans, 1952); idem, A Theology of the New Testament. Viviano, The Kingdom of God in History, 123-48, presents a general overview of the twentieth-century debate on the issue. Furthermore, a detailed survey of recent interpretations of the Kingdom of God is found in David $k$. Naugle, Jr., "A Theological Analysis and Evaluation of the Realized Eschatology of C. H. Dodd" (Th.D. diss., Dallas Theological Seminary, 1987), chap. 2. For a survey of the understanding of the Kingdom of God from the perspective of the philosophers of history see Karl Lowith, Meaning in History (Chicago: University of Chicago Press, 1949). See also p. 20 , n. 1. below.

'Jerald C. Brauer, "Kingdom of God," in A Handbook of Christian Theology, ed. Marvin Halverson and Arthur A. Cohen (Cleveland, OH: World Publishing Co., 1958), 197. Viviano (The Kingdom of God in History, 9), on the other hand, argues that the Kingdom is "of explosive power, " if only it is fully understood.

-Donald Attwater ("The Kingdom of God," A Catholic Dictionary [1958], 274-75) observes that in Roman Catholicism there is an insistence of interpreting the Kingdom of God as a spiritual rule rather than a temporal 
to reject any direct connection of the kingdom with sociopolitical concerns. For instance, Cardinal Joseph Ratzinger, Prefect of the Vatican Congregation for the Doctrine of the Faith, maintains that the concept of the Kingdom of God should be kept totally separate from matters of political responsibility for developments in history, since the realization of God's Kingdom is neither in itself a political process, nor does it consist in a modification of our earthly circumstances. Likewise, Rudolf Schnackenburg holds that the Kingdom preached by Jesus has primarily a religious character, stating:

The salvation proclaimed and promised by Jesus in this reign and Kingdom of God is purely religious in character. Jesus entirely excluded the national and political-religious elements from his "basileia" concept and repudiated the widespread Jewish hope of a splendid Messianic Kingdom of Israel.

rule. This spiritual rule of Christ over human beings is emphasized by the liturgical feast of Christ the king.

'Ratzinger, Eschatology: Death and Eternal Life, 5866. For Ratzinger, the message of the Kingdom of God is not a justification of the status quo. He considers that this message is "significant for political life not by way of eschatology but by way of political ethics" (ibid., 59). Thus, for him, to keep separate eschatology and politics is one of the Eundamental tasks of Christian theology.

-Rudolf Schnackenburg is Emeritus Professor of New Testament in the Catholic Theological Faculty of the University of Würzburg.

Schnackenburg, God's Rule and Kingdom, 95. The assertion of the kingdom as purely religious is judged by Jon Sobrino as "an oversimplification" because he does not see in Schnackenburg's argument--that Jesus avoided Iinking himself with apocalyptic and theocratic expectancies and messianic movements--any ground to support the idea of a 
Some scholars, while stressing the spiritual

meaning, recognize that Jesus' message of the Kingdom contains a sociopolitical aspect. Thus, Gerhard Lohfink criticizes traditional theology for ignoring not only the social aspect of the Kingdom, but also for considering that "the kingdom has no place in the world. It was briefly evident in Jesus, but now is a distant cloud in the air.": Furthermore, he proposes that God's Kingdom wants to change the hearts of people, their environment, and the society in which they live as well.'

purely religious Kingdom. Jon Sobrino, "Central Position of the Reign of God in Liberation Theology," in Magisterium Liberationis: Fundamental Concepts of Liberation Theology, ed. Ignacio Ellacuría and Jon Sobrino (Maryknoll, NY: Orbis, 1993), 366-67.

Gerhard Lohfink, "The Exegetical Predicament Concerning Jesus' Kingdom of God Proclamation, "TD 36 (1989): 105. Lohfink suggests that the suppression of the social aspect of the kingdom is a reaction to the tendency to equate the Kingdom with the church, society, or the state (ibid., II0).

-Ibid., 109. For G. Lohfink, God's Kingdom is established in the world "only when an entire society in all spheres of life lives according to God's social order" (ibid.). Oscar Cullmann, Jesus and the Revolutionaries, trans. Gareth Putnam (New York: Harper \& Row, 1970), 29-30, believes that Jesus indeed criticized the social injustice of his time, but instead of encouraging a revolt, he called for inner individual change. This internal change in turn should lead people to communion with God and to better relationships with their neighbors. Although Cullmann in his The State in the New Testament (New York: Scribner, 1956) emphasizes a connection between Jesus and the Zealots, in his latest work Cullmann presents Jesus as an eschatological radical, but not of this world as the zealots of his time. Similarly Martin Hengel, Was Jesus a Revolutionist? trans. William Klassen (Philadelphia: 
In recent decades, other theologians have challenged--not denied--the one-sided emphasis on the religious aspect of the Kingdom preached by Jesus. They argue that in Jewish society the religious and sociopolitical perspectives were inseparable, thereby Jesus' message of the Kingdom embraces all these dimensions.: Claude Geffré notes that in its attempt to make the gospel politically neutral, traditional theology has not only spiritualized its understanding of the kingdom of God but it has also relativized the historical examples of human liberation. While denying that Jesus preached a "purely inwarà Kingdom," Geffré insists that Jesus indeed came into

Fortress, 1971), 23-33, rejects the idea that Jesus was involved in any revolutionary movement to transform the social order of his time. "He cannot be party to those who-then as now--seek to improve the world by violence, "Hengel notes, "a violence which begins with a hate-filled defamation and escalates to bloody terror, to torture and mass murder" (ibid., 31). Hengel, on the other hand, also remarks that Jesus did not justify the status quo.

'Norbert Lohfink, "Religious Orders: God's Therapy for the Church," TD 33 (1986): 205. Viviano (The Kingdom of God in History, 18) criticizes the traditional interpretation of Rom 14:17--where the Kingdom of God is meant as "justice and peace and joy in the Holy Spirit"-suggesting private and purely spiritual blessings. "After all, peace means primarily the opposite of war, the tranquility of order, social order," Viviano argues, and "justice means justice, the virtue proper to all social relations; and joy, although it has an individual dimension to it, can mean a rejoicing precisely in the blessings brought by peace and justice" (ibid.).

'Claude Geffré is a French priest who studied at the Dominican Faculties of the Saulchoir. Since 1968, he has been Professor of Fundamental Theology at the Faculty of Theology of the Institut Catholique in Paris. 
conflict with religious and political leaders, and that

Jesus' death was a political event.:

In Latin American liberation theology, the notion of the kingdom of God has acquired great relevance. There is an increasing tendency to present the concept of the Kingdom as part of a theological basis for Christian involvement in the struggles for justice in the world." Leonardo Boff (b. 1944). Franciscan priest and Professor of Systematic Theology in Petrópolis, Brazil, observes that throughout history Christians have read about Jesus' message of the Kingdom and of his conflict with religious and political leaders. However, their situation has prevented them from perceiving the political echoes of their reading. Today, according to Boff, the very same message has acquired "an immediate political and existential significance."

"Claude Geffré, "A Prophetic Theology," Conc 6 (June 1974): 14. Juan Luis Segundo also believes that Jesus' message was simultaneously religious and political. Juan Luis Segundo, The Historical Jesus of the Synoptics, trans. John Drury (Maryknoll, NY: Orbis, 1985), 104-5.

-Viviano, The Kingdom of God in History, 10. The new interpretation of the kingdom of God, rooted in the praxis of liberation, is regarded by Claude Geffré ("A Prophetic Theology," 13) as "the most precious contribution of Latin American theology."

'Leonardo Boff, "Salvation in Jesus Christ and the Process of Liberation," Conc 6 (June 1974): 79. Boff also perceives the Kingdom of God not only as a spiritual reality but also as a universal revolution of the structures of the old world. That is why the message of the Kingdom is offered as good news for the poor (ibid., 81). Cf. Leonardo Boff and Clodovis Boff, Liberation Theology: From 
While the official Roman Catholic teaching tends to highlight primarily the spiritual nature and the future coming of the Kingdom, Gustavo Gutiérrez, and the liberation theology movement in general, have the tendency to emphasize more its historical and present reality. In so doing, Gutiérrez attempts to change the traditional emphasis on the transcendence of the Kingdom.' Quoting E. Schillebeeckx, Gutiérrez affirms that "the hermeneutics of the kingdom of God consists especially in making the world a better place.": Thus, he conceives the Kingdom as being "realized in a society of brotherhood and justice," " in which "God's love will be present and exploitation abolished."

Furthermore, Gutiérrez envisions the coming Kingdom as a gift." He perceives a relationship between this gift and the struggle for liberation. "The historical, political

Confrontation to Dialogue, trans. Robert R. Barr (San Francisco: Harper \& Row, 1986), 13-14, 26.

Gustavo Gutiérrez, A Theology of Liberation: History, Politics and Salvation, trans. and ed. Sister Caridad Inda and John Eagleson (Maryknoll, NY: Orbis, 1973), 159, 167-168, 176-178.

-Edward Schillebeeckx, quoted in Gutiérrez, A Theology, 13.

Ibid., 232.

iThe Power of the Poor in History, trans. Robert $\mathrm{R}$. Barr (Maryknoll, NY: Orbis Books, 1983), 14.

Gutiérrez, A Theology, 161, 177. 
liberating event," he writes, is a "salvific" experience: which aims at transforming unjust social structures and promoting a "complete communion of men with God and of men among themselves.": This, however, is not a genuine solution since the root of social evil, namely sin, remains. The coming of the Kingdom at the parousia will bring full salvation, for it will destroy sin, the root of all evil. Though Gutiérrez denies any confusion of the Kingdom of God with the establishment of a just society, " he describes the former in terms identical to those in which he defines historical liberation, i.e., "better living conditions, a radical change of structures, a social revolution. . a permanent cultural revolution." One may ask whether Gutiérrez will be able to overcome what seems to

Ibid., $159-160$.

-Ibid., 177; idem, The Truth Shall Make You Free: Confrontations, trans. Matthew J. O'Connell (Maryknoll, NY: Orbis, 1990), 16. It seems that Gutiérrez is aware of the danger of making the gospel the servant of purely political goals. To avoid it, he emphasizes an integral liberation of man which involves political and economic freedom as well as freedom from sin, a liberation that finds its fulfillment and ultimate meaning in the coming Kingdom. See McNamara, "Recent Trends and Developments in the Catholic Church," 352 .

'Gutiérrez, A Theology, 231.

irbid., 27-33. Gutiérrez seems to be more interested in dealing with present realities than with future events. Sharing Marx's idea of praxis, he asserts that our "real action in the present" is determined by fixing our eyes on the future. Ibid., 220. 
be an unresolved tension in his understanding of the Kingdom.

\section{Statement and Justification of the Problem}

This dissertation approaches the existent tension in the concept of the kingdom of God promoted by the Peruvian Roman Catholic theologian Gustavo Gutiérrez Merino, and attempts to evaluate if it is possible to speak about the Kingdom as having a transcendental dimension; while at the same time, it is identified with a just, fraternal society (a this-world project). Gutiérrez serves as professor in the Department of Theology and Social sciences at the Catholic Pontifical University in Lima, Peru. In addition to his various responsibilities, Gutiérrez also Eunctions as priest of a local parish in one of the most impoverished areas of Lima.

Gutiérrez's work has been chosen as the basis for this dissertation for several reasons. To begin with, his name is inseparably linked to the birth and development of Latin American Iiberation theology.: His volume, A Theology

\section{See Robert McAfee Brown, Gustavo Gutiérrez} (Atlanta: John Knox Press, 1980), 20, 21.

-Various theologians have recognized Gutiérrez's pioneering work. See, for instance, Edward Schillebeeckx, "Liberation Theology Between Medellin and Puebla," TD 28 $(1980): 4$. J. Andrew Kirk ("Liberation Theology in Latin America Today," ModCh 23 [1980]: 165) states that the documents of Medelinn "were considerably influenced by the thinking of such men as Gustavo Gutierrez." On his part, Philip Hefner asserts that Gutiérrez is perhaps the foremost 
of Liberation, first published in 1971, is considered the Magna Carta of the movement: Besides, given Gutiérrez's vocation as a Roman Catholic priest and one of the leading theologians of popular religion in Latin America, his influence on church and society has been widely recognized and can hardly be ignored.' Finally, Gutiérrez was chosen because his view on the Kingdom occupies a central place in his theology. Since liberation theology assigns primacy to the liberation of the poor, Jon Sobrino observes that

Iiberation theologian. "Theology Engagée: Liberational, Political, Critical," Dial 13 (1974): 192. Also, Lucas G. Mateo Seco affirms that Gutiérrez is considered the main exponent and most important theorist in the liberation theology movement. G. Gutiérrez, H. Assmann, R. Alves: teología de la Iiberación (Madrid, Spain: Editorial Magisterio Español, S.A., 1981), 37.

Alfred $T$. Hennely, "Courage with Primitive Weapons," Crosscur $28(1978): 12$.

- Kenneth Medhurst in his short article on Peru states that after Medelin (1968) the Roman Catholic hierarchy "was significantly influenced by liberation theology (which was pioneered by . . . Gustavo Gutierrez)." "Peru," in Religion in Politics: A World Guide, ed. Stuart Mews (London: St. James Press, 1989), 215. Regarding Gutiérrez's influence in Chile see Brian H. Smith, The Church and Polizics in Chile (Princeton, NJ: Princeton University Press, 1982), 232-233, 248-249. Some Roman Catholics assert that Gutiérrez "has profoundly influenced the Church's official reaching," and is considered the Father Congar of the third world. Gregory Baum, "Gutiérrez and the Catholic Tradition," Ecum 21 (September-October 1983): 83. James J. Bacik also affirms that it is possible that one can profit from Gutiérrez's radical refocusing of the Christian tradition "even if we do not accept his social analysis or buy his total theological package." Contemporary Theologians (New York: Triumph Books, 1989), 176. 
Gutiérrez's A Theology of Liberation "concludes that the Reign of God is the most adequate reality for expressing liberation."1 Jorge Pantelis," from the same point of view, remarks that the three levels of meanings of the term liberation in Gutiérrez's theology find their unity centered around the theme of the Kingdom.'

352 .

'Sobrino, "Central Position of the Reign of God,"

${ }^{2}$ Jorge Pantelis (b. 1938) is a Bolivian Methodist minister. He received his doctorate at the Union Theological Seminary of New York (1975). He wrote his dissertation on the kingdom of God and the church in the historical process of liberation.

jJorge Pantelís, "Reino de Dios e Iglesia en el proceso histórico de la liberación" (Ph.D. diss., Union Theological Seminary, 1975), 170. According to Antonio Pernia, together with salvation "the kingdom of God is a theme that occupies a central place in Gutiérrez' liberation theology." "The Kingdom of God in the Liberation Theology of G. Gutierrez, L. Boff, and J. L. Segundo" (Th.D. diss., Pontificia Universitas Gregoriana [Vatican], 1988) published as God's Kingdom and Human Liberation (Manila, Philippines: Divine word Publications, 1990), 46. Richard John Neuhaus, prior to his corversion to Roman Catholicism, recognized the "key role that the future, under the metaphor of the kingdom of God," plays in Gutiérrez's thinking. Besides, Neuhaus criticizes Gutiérrez's theology for having a politicized idea of God's Kingdom. "Liberation Theology and the Captivities of Jesus," WorldV (June 1973), repr., in Mission Trends $N^{\circ} 3$. Third World Theologies, ed. Gerald H. Anderson and Thomas E. Stransky (New York: Paulist, 1976), 48-49. Christopher Rowland points out that Gutiérrez's distinctive contribution is his "insistence on present history as the arena of the manifestation of the reign of God in the needs of the poor." "Reflections on the Politics of the Gospel," in The Kingdom of God and Human Society, ed. Robin Barbour (Edinburgh: T. \& T. Clark, 1993), 236-237. In his Models of the Kingdom (pp. 116-117), on the other hand, snyder situates Gutiérrez's views on the Kingdom as earthly utopia, because of his emphasis on building a just society as being Kingdom work, though the kingdom transcends human efforts. See also Emilio Nuñez and William D. Taylor, Crisis in Latin 


\section{Review of Literature}

A growing number of studies have appeared on different aspects of Gutiérrez's theological contributions. In most of these, he is studied as part of a broader investigation of the Iiberation theology movement of in connection with other theologians.' There are nine major works dealing strictly with Gutiérrez and his theology. None of these studies have focused exclusively on Gutiérrez's concept of the Kingdom of God. Three of these discuss his theology of liberation as such, 2 another two

America: An Evangelical Perspective (Chicago: Moody Press, 1989), 259-260.

'For instance, see Dean J. Brackley, "Salvation and the Social Good in the Thought of Jacques Maritain and Gustavo Gutierrez" (Ph.D. diss., University of Chicago, 1980); Richard F. Wilson, "Human Liberation and Theology: An Examination of the Theology of Gustavo Gutierrez, James J. Cone, and Mary Daly" (Ph.D. diss., Southern Baptist Theological Seminary, 1982); David C. Dixon, "A Critical Analysis of Liberationist Christology in the Writings of Gustavo Gutierrez, Leonardo Boff, and Jon Sobrino" (Ph.D. diss., Southwestern Baptist Theological Seminary, 1988); Raul L. Cotto-Serrano, "The Significance of Politics in the Liberation Theology of Juan Luis Segundo and Gustavo Gutierrez" (Ph.D. diss., University of Massachusetts, 1990); Daniel E. Crosby, "A Critique of the Pneumatological Paradigm in the Theologies of James D. G. Dunn and Gustavo Gutierrez: A Question of Eschatology" (Ph.D. diss., Southwestern Baptist Theological Seminary, 1990).

${ }^{2}$ The first was written in 1973 by José Brito Olivares ("La teología de la Liberación en Gustavc Gutiérrez" [Th.D. thesis, Université Catholique de Louvain]); it is an analysis of Gutiérrez's theology exposed mainly in his $A$ Theology of Liberation, and in which the author is complimentary of Gutiérrez. The second dissertation was written by Joseph $D$. Spinelia in 1981 ("An Evaluation of the Theology of Liberation as Presented by Gustavo Gutierrez" [Th.D. diss., 
attempt a systematic presentation of Gutiérrez's

ecclesiology, 1 while two works deal with his concept of

salvation.2 Furthermore, one work addresses his pilgrimage

Dallas Theological Seminary]). Like Brito Olivares, Spinella's analysis is based mostly on Gutiérrez's $A$ Theology of Liberation. Important themes such as sin, man, and salvation are considered only briefly by spinella. In his evaluation, the author is not in agreement with Gutiérrez.

In the third work written in 1989 by John Ronald Blue ("Origins of Gustavo Gutierrez' 'A Theology of Liberation'" [Ph.D. diss., The University of Texas at Arlington]), the origin of Gutiérrez's theology is traced by using four categories: cultural, economic, political, and religious. At the end, Blue concludes that liberation theology is a unique blend of humanism, Marxism, utopianism, and universalism.

:James B. Nickoloff, "The Church and Human Liberation: The Ecclesiology of Gustavo Gutierrez" (Ph.D. diss., Graduate Theological Union, 1989). The author shows that the church not only constitutes a principal object of inquiry in Gutiérrez's theology, but it also functions as the privileged locus, a theological source, a hermeneutical principle, and a norm of his theological discussion. Robert L. Breckenridge, "The Ecclesiology of

Gustavo Gutiérrez Merino: Contours, Sources and Impact" (Ph.D. diss., Southern Methodist University, 1993). This study provides an analysis of the theological origins and reception of the ecclesiology developed by Gutiérrez. Breckenridge's work is more a historical study than a theological one. The author suggests that Gutiérrez has one foot planted outsıde mainstream Roman Catholic theological and ecclesiological tradition, while his other foot is firmly in the Eion of the Roman Catholic mainstream.

'Miguel Maszanera analyzes Gutiérrez's use of two central elements--the perspective of the poor and the hermeneutic of praxis of liberation--and his understanding of three levels of mearing of the salvation-liberation concept. The author righlights some positive aspects of Gutiérrez's work and raises questions on issues which need more in-depth consideration, if not correction. (Teologia, salvación y liberación en la obra de Gustavo Gutiérrez

(Bilbao, Spain: Ediciones Mensajero, 1978). A second study was written by Peter wright Kendrick, "Christian Freedom and Liberation: A Biblical and 
towards socialism, ' while another deals with his concepts and images of God.2

There remains a dissertation, however, in which Gutiérrez's understanding of God's Kingdom is compared to that of other theologians. This study is authored by Antonio Pernia ${ }^{3}$ whose purpose is to contribute towards the elaboration of the eschatology of liberation theology. In seeking to accomplish that goal the author examines the points of convergence existing among three liberation

Theological Critique of the concept of Salvation in the Theology of Gustavo Gutierrez" (Th.D. diss., New Orleans Baptist Theological Seminary, 1990). The author criticizes Gutierrez for suggesting a concept of salvation winich is rot objective and reductionistic, if not unbiblical.

:Osvaldo Luis Mottesi, "An. Historically Mediated 'Pastoral' of Liberation: Gustavo Gutierrez's Pilgrimage Towards Socialism" (Ph.D. Ciss., Emory Uriversicy, 1985). It is a diachroric and symctronic anaiysis of the development of socialism in Gutiérrez in which Mottesi argues that Gutierrez's pilgrimage towards socialism is not yet Einished. It seems that the author has concentrated almost exclusiveiy on discussing whether Gutiérzez's opt:0: Eor socialism is relevant as a contextual historical mediation Eor Christian social ethics.

Mary I. Hynes, "Gustavo Gutierrez's Concepts and Images of God" (Pr.D. diss., Salne Louls University, 1991). According to Hynes, Gutiértez ider:ifies three major concepis of God: as graciols iove, Exiend cE life, and justice. Hynes atzempts $=0$ show lhat to fuily understand Gitzérzez's theology it is necessazy to discover what concepts and images of God it: Luence his thought, and that his ineology is based primar: $\because$ on $s=5: p=u r e$.

See p. i2, n. i above. Perria's anajysis of Gutiérrez's lindezstanding of lhe kingoiom of Goj is basej mostly o: Gutiérzez's ì Theo:og! of íberation. Tre autios brzefiy zouches cr trenes i ire sai:ation, shurch, and

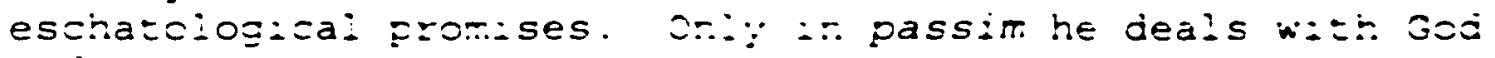
and $s: n$. 
theologians--G. Gutiérrez, L. Boff, and J. L. Segundo-regarding their understanding of the Kingdom of God.

Pernia's basic thesis is that liberation theology provides a new approach--of Iiberation--to the general debate on the Kingdom. ${ }^{1}$

Pernia explains that his investigation limits itself to an assessment of the general notion of the kingdom of God.2 In his evaluation, assuming that Gutiérrez's theology is an orthodox expression of Roman Catholicism, ${ }^{3}$ Pernia widely praises and agrees with the three theologians. Consequently, in Pernia's work there is no critical analysis of Gutiérrez orthodoxy. This omission not only leaves the field open for the present investigation but also calls for it.

'Pernia, God's Kingdom and Human Liberation, 21-22.

'Ibid., 2-3. The author bases his evaluation on the synthesis of tine points of convergence of the three theologians under consideration, and not on each of them. He states that "to do justice to an evaluation of each theologian's understanding of the Kingdom of God would entail an evaluation as well of the other concerns, if not of the entire thrust, of their liberation theologies," and that is "quite beyond the purpose of this study." Ibid., 3 . Thus there is no direct evaluation of Gutiérrez's understanding of the kingdom. This is a topic still to be evaluated.

${ }^{3}$ Ibid., 198, n. 9. Based on the presupposition that Gutiérrez's theology is orthodox and assuming that the political aspect is part of the gospel. Pernia does not take into consideration both the influence of Marxism on Gutiérrez's theological enterprise and the criticism against it found within Roman Catholicism. 


\section{Pufpose and scope of the study}

The purpose of this research is to examine Gustavo Gutiérrez's understanding of the kingdom of God and how the Kingdom comes into being. In order to accomplish this objective the study undertakes three tasks. First, it describes his understanding of the kingdom. Second, it analyzes it. Third, it evaluates his understanding against the background of the Roman Catholic position as set forth in the documents of the Second vatican Council.

A study of this kind implies limitations. While including aspects of Gutiérrez's overall system that impinge on the topic under discussion, this dissertation does not provide an in depth coverage of the total scope of his theology.

\section{out line of the study}

To understand Gutiérrez's view of the Kingdom of God one should have a clear comprehension of the diverse interpretations of the Kingdom throughout history.

Chapter 1 introduces the problem, giving a general overview of the contemporary debate about the kingdom of God and showing the relevance of Gutiérrez's contribution. It also addresses the purpose and limitations of the study as well as a review of pertinent literature.

Chapter 2 focuses on the historical and theological development of the concept of the kingdom of God within 
Roman Catholicism. A Protestant view on the Kingdom is also discussed. This chapter also provides a perception of Gustavo Gutiérrez as theologian--his life, methodology, and hermeneutics.

A description of Gutiérrez's view of the Kingdom of God is set forth in chapter 3. Attention is given to the way his view of God's Kingdom functions in his theology.

Chapter 4 describes and analyzes the concept of the Kingdom of God as portrayed in the Vatican II documents and the social doctrine of the Roman Catholic Church.

Chapter 5 attempts a comparative and evaluative analysis of Gutiérrez's understanding of the Kingdom in the light of the teachings of the second Vatican council on the issue. The final conclusions are presented as well. 


\section{HISTORICAL BACKGROUND}

In order to understand Gustavo Gutiérrez's perception of the Kingdom of God, one must first examine the understanding of this concept within Roman Catholicism and, particularly, the influence of the Roman Catholic Church in Latin America since its discovery and conquest.

The presence of Roman Catholicism in Latin America is felt, as W. Stanley Rycroft: remarks, "in every aspect of the life, in the economic, social, and political spheres." Therefore, according to Rycroft, a scholar well acquainted with the history of Roman Catholicism in Latin America, the present religious situation in this region "cannot be understood without a study of the forces that contributed to make it what it is today.":

W. Stanley Rycroft, born in England, worked in Peru between 1922 and 1940 under the auspices of the Free Church of Scotland. He received his doctorate in philosophy at the San Marcos University of Lima (1938).

-w. Stanley Rycroft, Religion and Faith in Latin America (Philadelphia: Westminster, 1958), 81. Norman F. Cantor, professor of history at State University of New York, The Meaning of the Middle Ages (Boston: Allyn and Bacon, 1973), 3, suggests that to understand the Roman Catholic Church today it is essential to have an understanding of the medieval world, because "what is 
To provide the necessary perspective, this chapter attempts to offer a brief exposition of the historical development of the understanding of the Kingdom of God in Roman Catholic thought, beginning with Augustine and proceeding to the time of Vatican II. It also includes a concise framework of the methodology used by Gustavo Gutiérrez. This overview provides a background for understanding Gutiérrez's stance on the issue.

\section{The Kingdom of God in the Roman Catholic Church from Augustine to Vatican II}

Throughout the history of Christianity, the biblical term "Kingdom of God" has been interpreted in basically

happening in the Church today represents a struggle between its surviving medievalism and attempts to go beyond medievalism." José Comblin also notices that no one can grasp the present situation of the Latin American Roman Catholicism without knowing something of the antecedents that created it. The Church and the National security state (Maryknol1, NY: Orbis, 1979), 50.

The intention of this survey is not to provide an exhaustive study of the issue, but to indicate the high points in the understanding of God's Kingdom in Roman Catholicism. There is a selected bibliography about the Kingdom of God in the history of western Christianity in John $E$. Groh, "The Kingdom of God in the History of Christianity: A Bibliographical Survey," CH 43 (1974): 257 67. A brief summary is found in Hūnermann, "Reign of God," 1349-57; Viviano, The Kingdom of God in History. Also an overall discussion of the Kingdom of God may be found in Archibald Robertson, Regnum Dei (New York: Macmillan, 1901); James $S$. Candlish, The Kingdom of God (Edinburgh: $T$. \& $T$. Clark, 1884). See also above p. 2, n. 2 . 
three ways.: It has been perceived generally as the transcendent reign of God in heaven. It has also been understood as the millennial and visible reign of Christ on earth between His second coming and the Last Judgment. A third interpretation has identified the Kingdom with the visible church on earth. $=$ of these three concepts the third dominated the thought and life of Roman Catholicism until the second vatican Council (1962-1965). The other two, however, have persisted, in a subordinate way, side by side

$$
\text { 'Viviano (The Kingdom of God in History, 30-56) }
$$
suggests that during the first millennium four main streams of interpretation about the kingdom of God were developed. The eschatological current understood the Kingdom as being in the future. The spiritual-mystical trend identified it either with a present spiritual good in the soul of the believer, like spiritual and intellectual illumination, or the practice of Christian virtue. A third stream perceived the Kingdom as being realized on earth with some political structure or program. The fourth view, called the ecclesial school, identified the Kingdom of God on earth with the church. Cf. John W. C. Wand, The Mystery of the Kingdom of God (London: Faith Press, 1953), 62-70; Alva J. McClain, The Greatness of the Kingdom (Grand Rapids, MI: Zondervan, 1959), 7-15.

-Robertson, Regnum Dei, 119. CE. Peter Kuzmic, "The Church and the Kingdom of God: A Theological Reflection, "in The Church: God's Agent for Change, ed. Bruce J. Nicholis (Exeter: Paternoster Press, 1986)，51-54; Hünermann, "Reign of God," 1354-57; Candlish, The Kingdom of God, 241-42; Georgia Harkness, Understanding the Kingdom of God (Nashville, TN: Abingdon, 1974), 62-65. 
with the belief which identifies the Kingdom with the church.:

The history of the understanding of the Kingdom of God in the early church is the history of the predominance and decline of Millenniarism." The belief in a millennial and visible reign of Christ to be inaugurated by his second Advent was dominant in the Western church for the first four centuries, up to the time of Augustine (354-430).

Before Augustine, the Kingdom was never explicitly identified with the church though some divergent ideas began to be developed, such as Eusebius's theory (c. 260-c. 340) that Constantine and his Christian empire were a form of the Kingdom of God on earth.; The Nicene theologians, on the

'Robertson, Regnum Dei, 169. See also Norman Cohn, The pursuit of the Millennium, rev. and enl. ed. (New York: Oxford University Press, 1970), 29; C. A. Alington, The Kingdom of God (London: Centenary Press, 1940), 88-93; Norman Perrin, Jesus and the Language of the Kingdom (Philadelphia: Fortress, 1976), 60-65; Wand, The Mystery of the kingdom, 62-70.

-Cohn, The pursuit of the Millennium, 19-29. For a concise survey of the millennial interpretation in early Christianity see Robertson, Regnum Dei, 120-65. Snyder (Models of the Kingdom, 28-34) also traces this interpretation and its implications in history.

Robertson, Regnum Dei, 124. Cf. G. H. S. Walpole, The Kingdom of Heaven (New York: E. P. Dutton, 1909), 6-10; Ennest F. Scott, The Kingdom of God in the New Testament (New York: MacMillan, 1931), 167-83.

iThe Oration of Eusebius Pamphilus 3.2-7 (NPNF, 1:584). See also Edward F. Cranz, "Kingdom and Polity in Eusebius of Caesarea," HTR 45 (1952): 47-66; George H. 
other hand, emphasized the double kingship of Christ: as God, Christ is king from eternity by nature; as man, he became king through his work of salvation.: Other theologians, such as Athanasius (c. 296-373), Hilary (c. 315-67), and Ambrose (c. 339-97), interpreted 1 Cor 15:24 ff. in the sense that the Kingdom which is handed back to the Father is identical with the faithful."

At the same time, the concept of the civitas Dei was developed in the fourth century to distinguish the two societies existing within the Roman Empire: the secular society--the Empire, and the city of God--the church. It

Williams, "Christology and Church-state Relations in the Fourth Century, Dt. I," CH 20 (September 1951): 17-19; Per Beskow, Rex Gloriae: The Kingship of Christ in the Early Church, trans. Eric Sharpe (Stockholm: Almquist \& Wiksell, 1962), 318-19; Viviano. The kingdom of God in History, 4647. A documented account of Eusebius's theory of the Christian empire as the Kingdom of God is found in Gerhart $B$. Ladner, The Idea of Reform (Cambridge, MA: Harvard University Press, 1959), 118-125.

For instance, see Athanasius Discourse II Against the Arians 14.11; 15.11, 17 (NPNF 4:354, 357); idem, De Synodis 49 (NPNF 4:476). Cf. Beskow, Rex Gloriae, 276-94. Beskow's study shows the different interpretations regarding the problem of whether the kingship of Christ began as man, in his birth, of in his glorification.

- See Athanasius De Incarnatione Dei Verbi, et Contra Arianos 20 (PG, 26:1019-22); Hilary on the Trinity 11.21-39 (NPNF, 9:209-14); Ambrose of the Christian Faith 5.12 (NPNF, 10:302-3). CE. G. H. Williams, "Christology and ChurchState Relations in the Fourth Century, Pt. 2," CH 20 (December 1951): 15-19; Beskow, Rex Gloriae, 286-87. This interpretation seems to suggest that God's Kingdom on earth is present in the church. 
was Ambrose who developed the notion of the civitas Dei and explicitly identified it with the church.'

As Robertson suggests, it is possible to detect

before Augustine an implicit relationship between the Kingdom and the church, which would indicate that the identification of these two entities was not entirely an innovation brought up by Augustine but rather grounded upon a revision of received exegesis. ${ }^{2}$

Augustine has a special place in the history of early Christianity for having deeply influenced the western Church and culture. ${ }^{3}$ His City of God is of particular

'Ambrose Expositio in Psalmum Cxviii sermo xv, 35 (PI, 15:1496). See translation in Williams, "Christology and Church-state Relations in the Fourth Century, Pt. 2," 16. Cf. Karl F. Morrison, "Rome and the City of God," TAPS 54, Pt. 1 (1964): 48, n. 60 .

${ }^{2}$ Robertson, Regnum Dei, 173-176. For Robertson this identification "was prepared for by the whole course of the Christian thought on the subject" (ibid., 173). Likewise, J. G. Davies (The Early Christian Church (New York: Holt, Rinehart and Winston, 1965], 224) affirms that many of Augustine's ideas found a beginning in Ambrose's thoughts.

${ }^{3}$ Carl-Erik Sahlberg, "Augustine--The African Who Influenced Europe," ATJ 21 (1992): 116. Augustine is considered as the intellectual father of the western Church because his thought illuminated and molded the whole theology of the Middle Ages down to the 13th century, when his writings were reinterpreted in the light of the Aristotelian philosophy introduced in the church by Thomas Aquinas. John Herman Randal1, "The Manifold Experience of Augustine," AS 38 (Winter 1968/69): 127. Cf. Daniel D. Williams, "The Significance of St. Augustine Today," in A Companion to the study of $s t$. Augustine, ed. Roy $W$. Battenhouse (New York: Oxford University Press, 1955), 3-5. 
significance since it develops the twofold principle which formed the foundation of the medieval theory of church and state.: On the one hand, the civil government is described as belonging to the world as distinguished from and opposed to the civitas Dei; on the other, the divine government of the civitas Dei is set forth as exercised through the bishops and their ecclesiastical discipline. ${ }^{2}$ Augustine identified the city of God with the church, the latter seen as the body of the elect. ${ }^{3}$ His

Henri Marrou (Saint Augustine and His Influence through the Ages [New York: Harper Torchbooks, 1957], 147-80), in dealing with Augustine's influence in the early Middle Ages, states that he was considered a "master without rival."

:The city of God is an exposition of Augustine's view of history as the coexistence and interaction of two cities, the city of God in which the love of God is expressed and the city of the world which is characterized by the love of self. Cf. Augustine The City of God 14.28 (NPNF, 2:282-63). Augustine's work came at the time when the Christian church was flourishing while the Roman Empire was falling before the barbarians. His natural reasoning was that the Kingjom of God was being established on earth while the last great heathen empire was being overthrown. Candlish, The Kingoiom of God, 249.

\section{${ }^{2}$ Candisst. The Kingdom of God, 413.}

${ }^{3}$ Augustine The City of God 13.16; 17.15 (NPNF, $2: 252,353)$; iciem Expositions on the Psalms xcviii.4 (NPNF, 8:484). Augustine craws a careful distinction between the essential churct. composed of those who genuinely belong to Christ being good and faithful, and the visible or empirical church. On Baptism, Against the Donatists $5.38 ; 7.99$ (NPNE, 4:476-77, 511-12). CE. Henry de Lubac, Catholicism, trans. Lancelot C. Sheppard (New York: Mentor-Omega Books, 1964), 47, n. 39; Robertson, Regnum Dei, 194-205; John N. D. Kelly, The Early Christian Doctrines, rev. ed. (New York: Harper \& Row, 1978), 415-16. 
Platonic background led him to perceive these two entities as having both an earthly form and their ideal and perfect form in heaven. Likewise, the Kingdom of God was envisioned as having its ideal and perfect form in heaven, i.e., a transcendent and otherworldly kingdom but being founded imperfectly on earth in the visible church, the earthly Kingdom.: Whether Augustine identified God's Kingdom with the body of the elect or with the visible church is a debatable issue.: But none can doubt that he made the connection between the Kingdom and the church. The identification of the kingdom of God with the church had great influence in the Middle Ages. This theory

See The City of God 15.1; 14.28; 20.9 (NPNF, 2:285, 282-83, 430). While discussing the end of the two cities, and after examining Revelation 20, Augustine concluded that Christ and his saints reign for one thousand years while the devil is bound. It is in this context of discussing Christ's kingship over the earth that Augustine identified the church with the Kingdom of God. He wrote: "Therefore the Church even now is the kingdom of Christ, and the kingdom of heaven. Accordingly, even now His saints reign with Him, though otherwise than as they shall reign hereafter." The City of God 20.9 (NPNF, 2:430).

-scholars still debate the relationship between Kingdom and church in Augustine's theology. Etienne Gilson states that it is true that for Augustine the church is the kingdom of God, "but it is not entirely true that it [the church] is the City of God." The Christian Philosophy of Saint Augustine, trans. L. E. M. Lynch (New York: Random House, 1960), 181. Cf. John N. Figgis, The Political Aspects of $S$. Augustine's 'City of God' (London: Longmans, Green, and Co., 192I), 68-80; Robertson, Regnum Dei, 194201. According to George Ladd (Crucial Questions About the Kingdom of God, 24), whether Augustine intended or not, "it is quite clear that medieval thought understood the kingdom in terms of the visible, ecclesiastical system." 
placed the church in an extraordinary and elevated position in society and contributed to forming what Herbert stroup has called the philosophic basis for the theory of the medieval papacy.: In fact, throughout the medieval era, the Roman Catholic church took a controlling position not only in theology but in society in general as well."

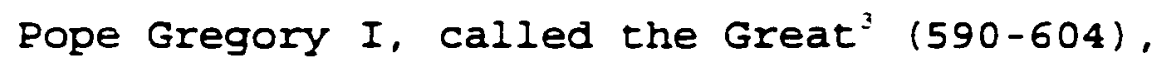

Herbert Stroup, Church and state in Confrontation (New York: Seabury Press, 1967), 102. Cf. Ennst Benz, Evolution and Christian Hope, trans. Heinz G. Frank (Garden City, NY: Doubleday, 1966), 34. Hans Küng also acknowledges the great influence of Augustine's view of the Kingdom through the whole Middle Ages. However, he notices that Augustine's distinction between the kingdom and "the political theology of the empire" was not pursued during this period. On the contrary, as küng states, medieval society had the certainty of the presence of God's Kingdom on earth. Hans küng, The Church, trans. Ray and Rosaleen Ockenden (New York: Sheed \& Ward, 1967), 90-91.

-A testimony of the dominant influence of the church in society is found in the Investiture Controversy (c. 10731122 ) where emperor and pope struggled to obtain supremacy in the secular and spiritual realms. J. Marcellus Kik, Church and State (New York: Thomas Nelson, 1963), 56. For a treatment of this issue see Bennett D. Hill, ed., Church and State in the Middle Ages (New York: John Wiley \& Sons, 1970), 63-194. CE. Karl F. Morrison, ed., The Investiture Controversy (New York: Holt, Rinehart and Winston, 1971); idem, "Introduction," in Imperial Lives and Letters of the Eleventh Century, ed. Robert Benson, trans. Theodor $\mathbf{E}$. Mommsen and Karl F. Morrison (New York/London: Columbia University Press, 1962), 3-51.

Gregory the Great is recognized by Roman Catholics as "the founder of the Middle Ages" and, particularly, of the medieval papacy. A Dictionary of the Popes (1939), s.v. "St. Gregory I, the Great." Brian Hebblethwaite (The Christian Hope [Grand Rapids, MI: Eerdmans, 1984], 58) calls Pope Gregory "the father of the medieval papacy." 
considered "the interpreter of Augustine to the Middle Ages,": played an important role in strengthening the claims of the primacy of the church of Rome and the papacy. In order to accomplish this task, he used the Augustinian identification of the Kingdom with the church." Thus he interpreted the Kingdom of God referred to in Luke 9:27 as the church opposed to the "power and the glory" of the world.

Centuries later, Thomas Aquinas (1225-74) claimed that God's Kingdom meant being under the rule of God. The term "Kingdom of God," however, had several meanings for him. It referred to the militant church, or community of believers who walk in faith to their ultimate goal. On the

Williston Walker, A History of the Christian Church (New York: Scribner, 1949), 172. J. N. D. Kelly, ("St. Gregory I," The Oxford Dictionary of Popes [1986], 67) describes Gregory the Great as an "effective summarizer of Augustine's teaching."

-Staehelin. Die Verkündigung des Reiches Gottes, $2: 75,77$. Gregory believed that God bestows sovereignty upon the emperor in order that the temporal kingdom may serve the heavenly Kingdom. When emperor Maurice promulgated an edict prohibiting anyone engaged in public administration or in military service from retiring into a monastery, Gregory wrote to him stating that this edict was in opposition to the divinely ordained relation of Empire to church, because the earthly kingdom should serve the heavenly one, i.e., the church. Robert Evans, One and Holy: The Church in Lazis Patristic Thought (London: SPCK, 1972), 144.

Gregory the Great Homiliarum in Evangelia Homilia xxxii (PL, 76: 1236-37). CE. Hünermann, "Reign of God," 1354 . 
other hand, it referred to the triumphant church, or the assembly of those who reached their final objective: heaven after death.: Following Augustine's perception, Aquinas also understood Revelation 20 as the present time in which Christ reigns with the saints, supporting in this way the identification of the Kingdom with the church.:

In general, from Gregory I onwards, the Roman Catholic Church has understood itself as the manifestation of God's kingdom on earth, a realm in which Christ reigned

Thomas Aquinas, Super Evangelium S. Matthaei: Lectura, ed. Raffaele Cai (Turin: Marietti, 1951), on ch. 3 , v. 2, par. 250; idem, Summa Contra Gentiles, 4.50. Cf. Staehelin, Die Verkündigung des Reiches Gottes, 3:294-95; Viviano, The Kingdom of God in History, 62-63. William E. Vinson ("The Kingdom of God according to Thomas Aquinas" [Ph.D. diss., Southwestern Baptist Theological Seminary, 1987]) argues that in Aquinas's theology God's Kingdom is the hierarchy of being which includes both the church and the state, the former being at the top and the latter at the bottom. Moreover, Vinson defends the thesis that the Kingdom of God in Aquinas's thought contains the nexus of his philosophy and his theology, and of the state and the church.

-Staehelin, Die Verkündigung, 3:292-93.

Eric W. Gritsch, "The Lordship of Christ in Christian History," in Christian Hope and the Lordship of Christ, ed. Martin J. Heinecken (Minneapolis, MN: Augsburg, 1969), 35. See also, Margaret Deansly, A History of the Medieval Church 590-1500 (London: Methen, 1960), 15-29; Benz, Evolution and Christian Hope, 26-27. According to Hans küng (The Church, 91), the Middle Ages in general were characterized by a "consciousness of a real kingdom of God present on earth." Although there were different interpretations, one thing was clear, "Christendom, the corpus christianum guided by regnum and sacerdotium, was for all practical purposes identical with the civitas Dei." A logical implication of equating God's Kingdom with the 
through his representative, the pope. This equation resulted, as Roger D. Haight observes, in a strengthening of the institutionalism of the visible church, and in "a tendency to absolutize and divinize the Church itself.":

church, as believed by E. L. Mascal, is that medieval society perceived the latter as a "great supra-political corporation, having much the same structure and organization as the kingdoms of this world, differing indeed from them in being concerned with supra-temporal end" (Corpus Christi [London: Longmans, Green and Co., 1953], 37). The notion of an ecclesiastical kingdom led the church to demand the political control over the state and, as $W$. H. Marsh remarks, to strengthen the pope's claim of having "the right to depose kings, to absolve subjects from all allegiance to their governments, and to invoke the secular power in putting down all dissent" (The New Testament Church

[Philadelphia: American Baptist Publication Society, 1898], $75, \mathrm{n} .2)$. See also McClain, The Greatness of the Kingdom, 438-39. A documented study on deposition of kings by popes is found in Samuel Edgar, The Variations of Popery (New York: S. W. Benedict, 1850), 210-38.

'Roger D. Haight, "Mission: The Symbol for Understanding the Church Today," TS 37 (1976): 623, 628, n. 13. Peter Hebblethwaite (Theology of the Church [Notre Dame, IN: Eides, 1969], 33) also acknowledges that where the church and the kingdom are equated exist the danger of institutionalization and absolutization of the visible church. According to Avery Dulles, a Jesuit expert on ecclesiology, the institutional model sees the church as a "perfect society" and tends toward "triumphalism," which makes the church identical with the Kingdom of God. Models of the Church (New York: Doubleday, 1974), 31-42. See Jerome A. Welch, Catholicism Today (Fort Wayne, IN: Jewel, 1977), 54. A reaction against absolutism and divinization of the church is found in Küng, The Church, 129-32, 239-41. "To apply to the Church what is said in the New Testament about the reign of God," küng notices, "will inevitably lead to an intolerable glorification of the Church, the presentation of an ecclesiologia gloriae with the church at its end." Ibid.. 92. Likewise, McClain notes that the equation of the church and the Kingdom causes the former to lose its transitional character and to become a church "not only in the world but also of the world." The Greatness of 
The decrees of the Council of Trent (1545-63),:

which set the tone for Roman Catholic theology for centuries to come, - do not ascribe any particular meaning to the term "Kingdom of God," nor do they contain a definition or description of the nature of the church. ${ }^{3}$ However, Trent's catechism published in 1566 provided some insights into the

the Kingdom, 459 (italics in the original). Similarly, $K$. E. Skydsgaard states that "the Church is never the Ultimate End (to eschaton), but is always oriented toward the Ultimate End, the Kingdom of God itself." "Kingdom of God and Church," SJT 4 (1951): 393 (italics in the original).

For a discussion on the Council of Trent see Hubert Jedin, History of the Council of Trent, 3 vols., trans. Dom E. Graf (London: Thomas Nelson, 1957-61). Trent imposed upon itself the double duty of responding to the issues raised by the Reformers and of defining the dogmas of the church. In the words of Justo González, "Whatever the Protestants attacked, now became official and final doctrine of the Catholic Church" (A History of Christian Thought, 3 vols. [Nashville, TN: Abingdon, 1970-75], 3:224).

- See John P. Dolan, Catholicism: A Historical Survey (Woodbury, NY: Barron's Educational Series, 1968), 149. According to William A. Herr, the decrees of Trent "remained the definitive statement of what the Catholic religion is and what it means down to our own time." This Our Church (Chicago, IL: Thomas More Press, 1986), 246.

See Jared Wicks, "Council of Trent," Dictionary of Fundamental Theology (1994), 1126. Commenting on this apparent exclusion, Yves Congar declares that it is a "strange fact, the Council, which was supposed to respond to the Reformation, did not deal with the ecclesiological problem." He goes on to say that Trent, however, "has allusions dispersed here and there about the classical ecclesiological themes." L'Église: De Saint Augustin à I'époque moderne (Paris: Éditions du Cerf, 1970), 364 ; see also William J. Sparrow-Simpson, The Catholic Conception of the Church (London: Robert Scott, 1914), 200-205. 
notion of God's Kingdom.: This Kingdom was described as spiritual and eternal, and at the same time identifiable with the militant church, "the society of all the faithful still dwelling on earth.":

\begin{abstract}
According to the Catechism of Trent, the phrase "Kingdom of God" has a variety of meanings: First, it refers to God's power over all creation and his providence to rule and govern all things, that is the kingdom of nature. Second, it is understood as "special providence" by which God protects the saints, and it is called the Kingdom of grace. Third, it also means "that Kingdom of His glory" prepared from the beginning of the world as mentioned in Matt 25:34. The Tridentine catechism makes clear that "the kingdom of grace must precede that of glory, for God cannot reign in anyone in whom his grace does not already reign." The Catechism of the Council of Trent, trans. John A. McHugh and Charles Callan (Rockford, IL: Tan, 1982), 522-24.
\end{abstract}

Ibid., 76, 99-100. Since the Roman Catholic Church considered itself as God's kingdom on earth, it follows, according to James Candlish, that God's will is infallibly communicated "through its officers, and enforced by its discipline, and the blessings of forgiveness, peace, joy and hope are bestowed through its ordinances" (The Kingdom of God, 399). In a similar way, the catechism asserts that only in the Roman Catholic Church can the believers find all the help to accomplish their eternal salvation. It states, "Jesus Christ reigns by faith in all who are within the bosom of our holy mother, the Church." The Catechism of the Council of Trent, 523-24. This emphasis on the visible church promoted a strong ecclesiocentrism of which Robert Bellarmine was an abiding influence. Bellarmine's De Controversiis Christianae fidei adversus huius temporis haereticos tribus tomis comprehensae provided a systematic formulation of the Tridentine theology, presenting it, as Giuseppe Alberigo writes, "as almost a transcription of the Council." "The Council of Trent," in Catholicism in Early Modern History, ed. John O'Malley (Ann Arbor, MI: Edwards Brothers, 1988), 222. See David S. Schaff, "Cardinal Bellarmine--Now Saint and Doctor of the Church," $\mathrm{CH} 2$ (1933): $41-55$. 
ConsequentIy, post-Tridentine theology concentrates on the Roman Catholic Church's claims of being an external, visible, and universal institution for salvation. This position reinforced even more the tendency to equate church and Kingdom and the teaching that outside of the Roman Catholic hierarchical organization there was no salvation. Like Trent, the First Vatican Council (1869-70) paid Iittle attention to the concept of the kingdom. Thus the traditional view according to which the church represented God's Kingdom on earth continued to prevail without being made explicit by a council. This notion came through prior to the Second Vatican Council (1963-65) in magisterial pronouncements of popes like Pius IX, Leo XIII,' Pius XI,

In the encyclical "Vix dum a Nobis" of March 7, 1874, to the Bishops of Austria, Pope Pius IX refers to the church as "[Christ's] visible Kingdom on earth." He goes on to say that "the Kingdom of God upon earth is the kingdom of a perfect society which regulates itself and governs itself according to its own laws and by its own power and by its own rulers." Papal Teachings: The Church, selected and arranged by the Benedictine Monks of Solesmes, trans. E. O'Gorman (Boston, MA: St. Paul Editions, 1962), 240.

-Leo XIII (encyclical "Satis cognitum" of June 29, 1896) spoke of the church as "a perfect society. . . the kingdom which God has raised up and which will stand forever" (ibid., 318-19).

Pius XI (encyclical "Quas Primas" of December 11, 1925) emphasized strongly the universal character of Christ's Kingdom and explicitly declared that the Church is precisely this Kingdom destined to cover the whole earth. See The Kinship of Christ, Encyclical Letter: "Quas Primas", prepared with analytical outlines, questions, scriptural references and bibliography by Gerald C. Treacy (New York: America Press, 1944). In a later encyclical ("Mortalium 
and Pius XII, as well as in the writings of Roman Catholic scholars such as John Alzog," Karl Adam," Bernard Lambert,' and Charles Journet." Some of these scholars, nevertheless,

animus" of January 6, 1928), Pius XI declared that the church is a "perfect society, by its very nature external and perceptible to the senses." This is why Christ "compared it to a kingdom, a household, a sheephold, [and] a flock" (Papal Teachings: The Church, 452).

'Pius XII, in his encyclical "Mystici corporis" of June 29, 1943, spoke of the church as "a kingdom in which all believers would pay the perfect homage of their intellect and their will" (Papal Teachings: The Church, 557). Likewise, in an allocution to the Lenten preachers in 1953, Pius XII declared that the church "is a kingdom whose keys are in the hands of him who received from Jesus the Eternal king the power of binding and loosing on earth and in heaven" (ibid., 686).

-J. Alzog (History of the Church, 3 vols., trans. F. $J$. Pabisch and Thomas S. Byrne [New York: Benziger Brothers, 1912], 1:153-54) affirms that Christ founded a visible church and called it indifferently the Kingdom of God, the Kingdom of Heaven, and the kingdom of Christ. Alzog writes: "Christ called this religious society, which he has already designated as the Kingdom of God, a Church" (ibid., italics in the original).

Referring to the nature of the church, Karl Adam states that it is the realization on earth of God's Kingdom. The Kingdom, proclaimed by Christ, "which grows great like the mustard seed, and Iike leaven permeates the world, and which like a field of corn shelters both wheat and cockle until the harvest," Adam believes, is implanted in the church's own being and there manifested (The spirit of Catholicism, rev. ed., trans. Dom Justin McCann [New York: Macmilian, 1954], 13); see also ibid., 31, 147, 169, 223.

According to B. Lambert, the Roman Catholic Church "is the Kingdom of God on earth, in a rudimentary stage; she [the church] is on pilgrimage, but she really is that Kingdom." Ecumenism: Theology and History, trans. Lancelot C. Sheppard (New York: Herder and Herder, 1967), 168.

"C. Journet believes that it was "impossible to avoid identifying the church and the kingdom. These are two 
referred to the Church as the beginning of the Kingdom which will be perfected beyond history.:

The Second Vatican Council brought a significant shift in ecclesiological perspective by distinguishing the church and the Kingdom of God. The Roman Catholic Church seems to have changed its institutional, juridical, and hierarchical emphasis. Today it seems to understand itself not as the kingdom but as a community in exile which is journeying to its promised land, the Kingdom of God.: In contrast with the dogmatic teachings found in many textbooks on ecclesiology before the council, the bishops suggested that the nature and mission of the church be understood in relationship and in subordination to God's Kingdom." Thus

notions but the same reality. The church is the kingdom and the kingdom the church." L'Eglise du Verbe Incarné, 2 vols.

(Paris: Descleé de Brouwer, 1962), 2:997, n. I.

See for instance Adam, The Spirit of Catholicism, 13, 31, 81-82, 240-41; Lambert, Ecumenism, 168-69, 188-89.

Second Vatican Council, "Dogmatic Constitution on the Church," arts. 6, 9, in Walter M. Abbott, ed., The Documents of Vatican II (New York: America Press, 1966), 19$20,26)$. Hereafter referred to as "Abbott."

Avery Dulles observes that the institutional aspects of the church, which characterized the postTridentine Roman Catholicism, "are somewhat subordinated" in the Constitution on the Church. "The Catholic Ecclesiology since Vatican II," in Synod 1985: An Evaluation, ed. Giusseppe Alberigo and James Provost (Edinburgh: T. \& T. Clark, 1986), 4. Likewise, Frans J. Van Beeck (Catholic Identity After Vatican II [Chicago: Loyola University Press, 1985], 34) considers the shift of emphasis from embodiment of the Kingdom to sacrament of the kingdom the "single most significant reversal of ecclesiological perspective brought 
the church is a pilgrim whose mission is not to take the place of the kingdom, but to serve it.:

While the council made a distinction between the church and the Kingdom, it came close to identifying them when it declared that the church is on earth "the initial budding forth" of the kingdom." As such the church is the Kingdom of God growing visibly in the world."

about by Vatican II." This new perception of the church, according to $R$. McBrien, "replaces what was perhaps the most serious pre-Vatican II ecclesiological misunderstanding, namely, that the Church is identical with the Kingdom of God. If it is, then it is beyond all need for institutional reform, and its mission is to bring everyone inside lest salvation elude them." Richard P. McBrien, Catholicism: Study Edition (Minneapolis: Winston Press, 1981), 686. Nevertheless, the distinction between the church and the Kingdom made by the council has a precedent. As Viviano (The Kingdom of God, 135) remarks, Schnackenburg is the first to break definitively with the identification of the kingdom on earth as the church. See Schnackenburg, God's Rule, 284-302, 355 .

John Fuellenbach, "Kingdom of God," Dictionary of Fundamental Theology (1994), 593. John Linnan, "Dogmatic Constitution on the Church, Lumen Gentium and Decree on the Pastoral office of the Bishops in the Church, Christus Dominus," in Vatican II and Its Documents, ed. Timothy E. O'Connell (Wilmington, DE: Michael Glazier, 1986), 49, commenting on Lumen Gentium states that the distinction between the church and the Kingdom "undercuts those triumphalist tendencies to identify the Church as the Kingdom of God on earth." A similar idea is found in Richard P. McBrien, Church: The Continuing Quest (New York: Newman Press, 1970), 33.

Second Vatican Council, "Dogmatic Constitution on the Church," art. 5 (Abbott, 18).

Ibid., art. 3 (Abbott, 16). 
It appears that by adopting a dual position, the council left open the question about the identity or lack of identity between the church and the Kingdom. This issue will be dealt with in greater detail in chapter 4.

To complement the Roman Catholic view on the Kingdom, a brief overview of the Protestant understanding of God's Kingdom is helpful to better understand the current stance of Roman Catholicism, and of Gutiérrez in particular, on the issue.

\section{Protestant View on the Kingdom of God:}

In response to the Roman Catholic theologia gloriae which exalted or tended to exalt the visible church as God's Kingdom on earth, the Reformers emphasized its spiritual and invisible significance. They stressed that the kingdom is not identical with any organization. Thus, Martin Luther (1483-1546) conceived it as a kingdom of grace and mercy, :

A short discussion of contemporary Protestant interpretations of the Kingdom of God may be found in Perrin, The Kingdom of God in the Teaching of Jesus; idem, Jesus and the Language of the Kingdom, 65-88; Ladd, A Theology of the Nen Testament, 57-69; idem, Crucial Questions about the Kingdom of God, 25-39; Dennis C. Duling, "The Kingdom of God in the Teaching of Jesus," WW 2 (1982): 117-26; Bruce Chilton. "Introduction," in The Kingdom of God, ed. Bruce Chilton (Philadelphia: Fortress, 1984), 1-26.

- Martin Luther contrasted the Kingdom of God with the world which is one of wrath and severity, "An Open Letter on the Harsh Book Against the Peasants," in Luther's Works, ed. Robert Schultz, trans. Charles M. Jacobs (Saint Louis, MO: Concordia Publishing House; Philadelphia, PA: 
whereas John Calvin (1509-64) identified it with the invisible church, the company of the elect from the beginning of history.

Under the influence of the Enlightenment, new perspectives emerged in the understanding of the kingdom of God. Immanuel Kant (1724-1804), for example, envisioned the kingdom as an "ethical commonwealth under divine moral legislation." He called this commonwealth a church. Because of his different approach to church institutions and his deistic view, Kant reduced God's Kingdom and Christianity to morality and conscience."

$$
\text { Most nineteenth-century German New Testament }
$$

scholars followed Kant's moralistic presuppositions in interpreting the Kingdom of God. Thus, Albrecht Ritschl

Fortress Press, 1958-1986), 46:69.

Calvin did not define the church in terms of an historical organization. Cf. John Calvin, The Institutes of the Christian Religion 3.20.42, trans. Ford Lewis Batrles, ed. John T. MCNeill, LCC, 21:904-6; ibid., 4.7.29 (LCC, $21: 1147-48)$. For a brief discussion of the relationship between the church and the kingdom of God in Calvin's theology see John Leith, John Calvin's Doctrine of the Christian Life (Louisville, KY: Westminster; John Knox Press, 1989), 172-75.

- Immanuel Kant, Religion Within the Limits of Reason Alone, trans. and introd. Theodore $M$. Greene and Hoyt $H$. Hudson (New York: Harper \& Brothers, 1960), 92.

Ibid., 92, 127, 139-40; idem, Critique of Practical Reason, trans. and intro. Lewis White Beck (New York: BobbsMerrill, 1956), 133. See also Viviano, The Kingdom of God, 102 . 
(1822-89) saw the Kingdom as a supernatural ideal of spiritual and moral perfection that could be partially realized in history by human effort in accordance with God's will and the gift of his spirit.' By calling for a united human action motivated by universal love to advance the Kingdom of God in the world, Ritschl' laid the foundations for the social gospel which conceived God's Kingdom as a new social order based on the dignity and worth of the human person.

In contrast to these spiritualizing and moralistic interpretations, Johannes Weiss (1863-1914) proposed a different approach. He maintained that the realization of

See Albrecht Ritschl, Three Essays, trans. Philip Hefner (Philadelphia: Fortress, 1972), 222-32; idem, The Christian Doctrine of Justification and Reconciliation, ed. H. R. Mackintosh and A. B. Macaulay (Clifton, NJ: Reference Book Publisher, 1966), 279-84, 334-35. CE. James Orr, The Ritschlian Theology and the Evangelical Faith, 2d ed. (New York: Thomas Whittaker, 1898), 258-60; Eric G. Jay, The Church (Atlanta: John knox Press, 1980), 251-58.

- For a brief discussion of the German social movement in connection with Ritschl, see Gösta Lindström, The Kingdom of God in the Teaching of Jesus (Edinburgh: Oliver and Boyd, 2963), 18-23.

According to $W$. Rauschenbusch, the main exponent of the social gospel. the kingdom of God "embraces the whole of human life. It is the Christian transfiguration of the social order." is theojogy for the Social Order (Nashville: Abingdon Press, 1961), 145. For a selection of $W$. Rauschenbusch's statements on the Kingdom of God, see $A$ Gospel for the Social Awakening: Selections from the Writings of Walter Rauschenbusch, comp. Benjamin E. Mays and intro. C. Howard Hopkins (New York: Association Press, 1950), chap. 2 . 
God's Kingdom was not a matter of human initiative, but of God's initiative that would establish that kingdom in the future: Likewise Albert Schweitzer (1875-1965) held that Jesus consistently proclaimed that the Kingdom of God was imminent, never present." Thus, for these two scholars, God's Kingdom "was altogether eschatological." ${ }^{3}$

Reacting against Schweitzer's view, Charles H. Dodd (1884-1973) proposed a "realized eschatology," asserting that Jesus preached the Kingdom as already present, as already realized in his own ministry, and not to be considered as a future project.' From a different perspective, Rudolf Bultmann (1884-1976) accepted that God's kingdom is "a power which, although it is entirely future,

'Johannes Weiss, Jesus' Proclamation of the Kingdom of God, trans. and ed. R. H. Hiers and D. L. Holland (Philadelphia: Fortress, 1971), 132-36. Weiss states that Jesus saw the kingdom of God as the "objective messianic kingdom" rather than as something "subjective, inward, or spiritual" (ibid., 133).

See Albert Schweitzer, The Mystery of the Kingdom of God, trans. Walter Lowrie (New York: MacMillan, 1950), $58,162-63$. 29.

Ladd, Crucial Questions About the Kingdom of God,

'Charles H. Dodd, The Parables of the Kingdom

(London: Nisbet \& Co., 1936), chap. 2, esp. pp. 43, 53-55. 
wholly determines the present" and demands an existential decision now.

The futurist and the realized eschatology have been synthesized together to form a new view: the Kingdom of God as being both present and future. This idea constitutes a growing consensus among many Protestant scholars such as Joachin Jeremias (1900-79), Oscar CulImann (b. 1902)," Werner G. Kümmel (b. 1905), Jürgen Moltmann (b. 1926), ”

'Rudolf Bultmann, Jesus and the Word (New York: Scribner, 1958), 51-52 (italics in the original). For a brief summary of Bultmann's view on the Kingdom, see Perrin, The Kingdom of God in the Teaching of Jesus, 112-29.

Joachin Jeremias, The Parables of Jesus, trans. S. H. Hooke (London: SCM Press, 1954), 89-99; idem, New Testament Theology, 129.

Oscar Cullmann, Christ and Time: The Primitive Christian Conception of Time and History, rev. ed. (Philadelphia: Westminster Press, 1964), 83-87. Cullmann uses a metaphor from warfare to explain the tension between present and future in Jesus' teaching of the Kingdom: Although Satan has been defeated by Jesus, the war. nevertheless, continues, and will continue, until the parousia.

Werner G. Kümmel, Promise and Fulfillment: The Eschatological Message of Jesus, trans. Dorothea M. Barton (Napervilie, IL: A. R. Allenson, 1957), 141-55.

"Jürgen Moltmann, Theology of Hope: On the Ground and Implications of a Christian Eschatology (New York: Harper \& Row, 1967), 16. 
Wolfhart Pannenberg (b. 1928), : and George Eldon Ladd (b. 1911).:

In other words, the European and North American discussions of God's Kingdom have revolved around the following positions: (1) the identification of the Kingdom with the church by Roman Catholicism; (2) the distinction between the two by the Reformers; (3) the Kingdom as being brought about by human effort--Kant, Ritchl, Rauschenbusch; (4) the Kingdom as a future act of God to which human beings can contribute nothing, just wait and pray for it--Weiss, Schweitzer; (5) the Kingdom as a future reality--Weiss, Schweitzer; (6) the kingdom as a present reality--Dodd; and (7) the kingdom as future, but impinging on the present-Bultmann; (8) today the kingdom is believed to be present and future--Cullmann, Ladd, Moltmann, and Pannenberg among others.

Since the mid-twentieth century Roman Catholic theologians have changed their perception of eschatology as the result of their interaction with protestants. In increasing numbers Roman Catholics also have adopted the notion of the kingdom as present and future. According to

Wolfhart Pannenberg. Theology and the Kingdom of God, 53-54, 62 EE.

-Ladd, The Gospel of the Kingdom, 24-51.

Roman Catholicism in the New World, as an extension of European medieval Christianity, has traditionally equated the Kingdom of God with the church. 
Zachary Hayes, professor of systematic theology and the history of Christian doctrine at the Catholic Theological Union in Chicago, Roman Catholic thought on eschatology is indebted to renowned Roman Catholic theologians such as Karl Rahner and $H$. Urs von Balthasar as well as to prominent Protestant theologians such as Bultmann, Jeremias, Cullmann, Moltmann, and Pannenberg. Without their contribution, Hayes affirms, "the present perspectives on eschatology lwithin Roman Catholicism] would be simply impossible.":

Having reviewed briefly the understanding of the Kingdom of God within Protestantism, this study now turns to Roman Catholicism's presence and influence in Latin America. The equation of the Kingdom with the church had a major impact on the perception and organization of the Roman Catholic Church, not only in Europe but also in the New World.

\section{Latin American Historical context \\ Roman Catholicism and the Conquest of Latin America}

The process of the discovery and conquest of the New World by Portugal and Spain has been described as an enterprise intending to carry out the task of spreading

Zachary Hayes, Visions of a Future: A Study on Christian Eschatology (Wilmington, DE: Michael Glazier, 1989), 13 . 
Christendom into the new territories.' In this venture, the Roman Catholic Church exercised a central role. Some have emphasized the fact that this church functioned as an instrument of conquest and colonization of native Latin Americans.- Others have maintained that Roman Catholic

See León Lopetegui and Félix Zubillaga, Historia de la Iglesia en la América Española, desde el descubrimiento hasta comienzos del Siglo XIX (Madrid: Editorial Católica, 1965), 213-14. There is abundant literature about the discovery and conquest of the American continent. A comprehensive bibliography dealing with this issue is found in "Bibliographical Essays," in The Cambridge History of Latin America, vol. 1, ed. Leslie Bethell (Cambridge: Cambridge University Press, 1984), 557-623.

Thus, C. H. Haring affirms that both the Roman Catholic Church and the Spanish crown mutually supported one another. "The Church defended the divine sanctity of kings," Haring comments, and "the crown upheld the ecumenical authority of the Roman Catholic Church." Clarence H. Haring, The Spanish Empire in America (New York: Oxford University Press, 1947), 179. According to Severino Croato, Roman Catholicism also functioned as a religion of oppression. "The Gods of Oppression," in The Idols of Death and the God of Life: A Theology, ed. Pablo Richard et al. (Maryknoll, NY: Orbis, 1983), 43. Likewise, Riolando Azzi, "La teologia en el Brasil: consideraciones históricas," in Materiales para una historia de la teología en América Latina, ed. CEHILA (San José, Costa Rica: Departamento Ecuménico de Investigaciones, 1980), 72-73, states that the transmission of the doctrine was conditioned by keeping the latifundista and slave structure requested by those in power. Similarly, Antonio Celso Queiroz, auxiliary bishop of Sâo Paulo, writes: "Let us remember the colonial period when the Church was practically a colonization state Department," quoted by Azzi, 75. See also Richard E. Greenleaf, The Roman Catholic Church in Colonial Latin America (New York: Alfred A. Knopf, 1971), 1. 
missionaries were agents of evangelization and instruments for moderating the rapaciousness of the conquistadores.:

In Europe, the influence of the Roman Catholic

Church was felt in every aspect of the Iberian society. It was perceived not only in the social and religious life of the people, but in politics and economics as well." The medieval conditions in the Iberian peninsula in the sixteenth century found their last expression in the colonies established in the new lands. ${ }^{3}$ As a result, Latin

See Denise L. Carmody and John Carmody, Roman Catholicism: An Introduction (New York: Macmillan, 1990), 67; Enrique Dussel, A History of the Church in Latin America, trans. and rev. Alan Neely (Grand Rapids, MI: Eerdmans, 1981), 44-46. According to E. Dussel, through the system of the Patronato Real the papacy ceded to the spanish and Portuguese governments the right and responsibility of propagating the Eaith among peoples in the newly discovered lands. "This was the first time in history," Dussel comments, "that the Papacy gave to a nation the twofold authority to colonize and evangelize" (ibid., 38).

See E. Bradford Burns, Latin America: A Concise Interpretative History (Englewood Cliffs, NJ: Prentice-Hall, 1972), 58-63. According to Burns, Iberian society was so identified with Roman Catholicism that for people to be Spanish or Portuguese was to be Roman Catholic. They were born, reared, married, and buried Catholics. Consequently, church and state appeared as one (ibid., 58). See also Rycroft, Religion and Faith in Latin America, 106.

While in the rest of Europe the era of the Middle Ages had waned, in Spain it remained strong. Thus, the history of colonialism has been depicted as "the history of the medieval Europe without the strife of the Investiture." Luis Weckmann, "The Middle Ages in the Conquest of America," in History of Latin American Civilization, vol. 1, ed. Lewis Hanke (Boston: Little, Brown and Co., 1967), 18. For a pertinent discussion on the role of the Roman Catholic Church in the conquest and colonization of Latin America, see Greenleaf, The Roman Catholic Church in Colonial Latin 
American culture was shaped by the all-pervading influence of religion:

A few years before the discovery of the New World, the Spanish theologian John of Torquemada (1388-1468), considered "one of the greatest ecclesiologists of the fifteenth century," wrote his Summa de Ecclesia. It was published posthumously in 1489. According to Peter Riga, one finds in it strong evidence of the extreme emphasis on the external nature of the church." Torquemada discusses the church as a society, a kingdom outside of which there is no salvation. He also affirms that the institutional church of his days was the result of a development in accordance

America, 1-15; J. Lloyd Mechan, Church and State in Latin America (Durham, NC: University of North Carolina Press, 1966), 3-37; John A. Mackay, The Other Spanish Christ (New York: Macmillan, 1932), 23-41. Cf. Jeffrey Klaiber, The Catholic Church in Peru, 1821-1985 (Washington, DC: Catholic University of America Press, 1992), 8-12. For a summary on the church of colonial Christendom, see Amin A. Rodor, "The Concept of the Poor in the Context of the Ecclesiology of Liberation Theology" (Ph.D. diss., Andrews University, $1986), 38-63$.

All the organizations and doctrines existent in the Iberian peninsula at the time of the discovery of the Americas shaped the society in the new land. According to David M. Traboulay, the Latin American universities were structured after the medieval educational philosophy, and this left an enduring mark on the character of Spanish colonial civilization. David $M$. Traboulay, "The Church and the University in Colonial Latin America," ZMissR 63 (1979): $283-94$.

-Peter Riga, The Church Renewed (New York: Sheed and Ward, 1966), 63 .

Ibid. 
with God's will.: This very notion of the church was

transported to the new lands with far-reaching implications

for the history of Christianity, particularly Latin American

Roman Catholicism.

Luis E. Valcárcel, a Peruvian historian, describes the result of the encounter of European and Indian religions as a spiritual and cultural syncretism. ' Roman Catholicism was adopted by Latin American natives without abandoning their traditional beliefs. The Indians became nominal Roman Catholics because they did not understand the meaning of the new forms of worship. As $W$. Stanley Rycroft observes, "One

'Jay, The Church, 140-41. Torquemada's Summa de Ecclesia is considered of greatest importance because, as Jay notices, it sets out clearly the papal idea of the church and because it was from this work that "all subsequent defenders of papal primacy, including Bellarmine, up to the First Vatican Council drew their arguments" (ibid., 141).

-According to Luis E. Valcárcel, the Indians, not being able to reject the predominant and decisive religious values of Roman Catholicism, simulated their acceptance. Indians became Roman Catholics through baptism and took part in all the rites and feasts, but in their hearts, they were still faithful to their ancient gods. The clergy, to make an easy transition from paganism to Christianity, built their temples over Incaic sanctuaries, the Gregorian calendar was adapted to the Incaic calendar, Corpus Christi was celebrated at the same time of the feast of Inti-Raymi, a celebration in honor to the sun. Thus, while the clergy thought they had succeeded in covering, with new religious structures, the old pagan idolatry, the Indians rejoiced in worshiping their own deities in the same sacred places and on the same dates. Luis E. Valcárcel, Ruta cultural del Perú ([Mexico City], México: Fondo de Cultura Económica, 1945), 165. Cf. Rycroft, Religion and Faith in Latin America, 111-12; Lopetegui and Zubillaga, Historia de la Iglesia en la América Española, 319-20. 
of the tragedies of Latin America today is the continued outward religious observance, without the inward transformation of the individual.":

Five centuries of history provide evidence that, by and large, the presence of Roman Catholicism in Latin America has done little to uplift the Indians, due mainly to the fact that the people's religion was built on emotion, ritualism, celebrations, and feasts.' As Rycroft remarks, religion has brought neither redemption, nor better conditions of life, nor social uplift to the Indians."

'Rycroft, Religion and Faith in Latin America, 109. By the end of the sixteenth century, the Council of Lima noted that "idolatrous rites were continuing under cover of Christian ceremonies." Jean Delumeau, Catholicism between Luther and Voltaire, trans. Jeremy Moiser (London: Burns \& Oates, 1977), 90. One of the consequences of the Roman Catholic importation into the New World was the development of a popular religion formed by a mixture of pagan myths and Roman Catholic beliefs. Currently, this syncretism is still strong in Latin American culture, especially among poor people. For a pertinent study on this subject see Michael R. Candelaria, Popular Religion and Liberation (Albany, NY: State University of New York Press, 1990); Eugene A. Nida, "Christo-Paganism," PA 8 (1961): 1-15.

-Sante Uberto Barbieri, The Land of Eldorado (New York: Friendship Press, 1961), 14. Since the beginning of the conquest and colonization, the Roman Catholic priests made no attempt to block the Indian feast days; instead, the pagan ecstasy was converted to Christianity by the addition of a Mass, a benediction, and a saint's day. See John Collier, Jr. and Aníbal Buitrón, The Awakening Valley (Chicago: University of Chicago Press, 1949), 101.

W. Stanley Rycroft, ed., Indians of the High Andes (New York: Committee on Cooperation in Latin America, 1946), 300 . 


\section{Roman Catholicism in Contemporary}

Latin America

Among other things, Latin American Roman Catholicism inherited from its European model the identification of the Kingdom with the church. This notion was advocated in the New World by Catholic priests and friars who accompanied Spanish conquistadors in their conquest of Latin America.: Medieval theology and its emphasis on the spiritual dimension of the Christian faith found itself imported into the new territories.: As a result, the belief prevailed in Latin America that the Kingdom of God $^{3}$ is spiritual and

"Victor Codina, "Tres modelos de ecclesiología," EstEcl 58 (1983): 59-63; Ricardo Planas, Liberation Theology: The Political Expression of Religion (Kansas City, MO: Sheed \& Ward, 1986), 21, 31. See also Hans-Jürgen Prien, La historia del cristianismo en América Latina (Salamanca. España: Sigueme, 1985), 14, n. 9 ; Roberto Oliveros, Liberación y teología; génesis y crecimiento de una reflexión (1966-1976) (Lima, Perú: Centro de Estudios y Publicaciones, 1980), 27-29; Pantelís, "Reino de Dios e Iglesia en el Proceso Histórico de la Liberación, 4.

-CE. Planas, Liberation Theology, 29. See also Monika K. Hellwig, "Eschatology," in Systematic Theology: Roman Catholic Perspectives, vol. 2, ed. Francis schüssler Fiorenza and John P. Galvin (Minneapolis: Fortress, 1991), 365-67.

Catechism of the Catholic Church (Chicago: Loyola University Press, 1994), 272, 275. Cf. The Catechism of the Council of Trent, 76. The Universal Catechism of Vatican II refers to God's Kingdom as being already inaugurated on earth by Christ (Catechism of the Catholic Church, 145. 229). Though it is incomplete in the present age (ibid., 174-75), the kingdom will have its ultimate realization at the second Coming of Christ (ibid., 272, 275, 676). It also states that Christ will realize the coming of his Kingdom, and it will not be achieved through any historical triumph 
eternal, while at the same time it is represented on earth by the visible church,' i.e., the Roman Catholic Church.

The second Vatican Council brought a change in attitude in the Roman Catholic approach to the modern world in general.: The temporal affairs, unconsciously relegated to a secondary plane in Medieval theology, were paid much

of the church (ibid., 138, 177). This catechism does not mention any meaning of the term "Kingdom of God" as the Catechism of Trent does. See p. 32, n. 1 above.

Catechism of the Catholic Church, 138, 145, 174175, 201-203. Commenting on the "Provisional Text"--also called "Revised Draft"--of the Universal Catechism issued on November 1989, Dulles observes that this draft identifies the church and the Kingdom of God as being two different points of view by which the same reality is designated. Avery Dulles, "The Church in the Catechism," in The Universal Catechism Reader, ed. Thomas J. Reese (San Francisco: Harper, 1990), 86. Cf. Richard P. McBrien, The Remaking of the Church (New York: Harper \& Row, 1973), 32 ; Ludwig Ott, Fundamentals of Catholic Dogma, trans. Patrick Lynch (Cork, Ireland: Mercier Press, 1957), 270, 296-97.

'José Comblin, "The Church in Latin America after Vatican II," LADOC 7 (Jan.-Feb. 1977): 1 . Enrique Dussel points out that after Vatican II "a radical change in attitude" took place in Roman Catholicism. Now the church is oriented "to defend the rights of the poor and the common people." History and Theology of Liberation, trans. John Drury (Maryknoll, NY: Orbis Books, 1976), 120. Cf. Jay, The Church, 318-19. Regarding the impact of this Council on Latin American theologians, Ferm states, that only "since Vatican II has it become possible for us to stop being 'colonial." Dean W. Ferm, "South American Liberation Theology," RL 48 (1979): 481. For a further discussion, see Comblin, "The Church in Latin America," 1-18; Mark McGrath, "Church Doctrine in Latin America After the Council," in The Church and Social Change in Latin America, ed. Henry A. Landsberger (Notre Dame, IN: University of Notre Dame Press, 1970), 97-112; Planas, Liberation Theology, 57-61; Oliveros, Liberación y teología, 49-110. 
attention.: The council not only gave a more prominent place to the sociopolitical role of the Christian faith, but also recognized the religious and spiritual dimensions of Christians' temporal duties by attaching those duties to salvation.: Latin American Roman Catholics took seriously the call of the council bishops to be "at the service of the world," and looked for new ways to find what they regarded as just solutions to the problems of Latin America. In doing so, they found help in the Marxist analysis of society.

Kevin McNamara, "Recent Trends and Developments in the Catholic Church," Mid-Stream 18 (1979): 351. Commenting on chap. 3 of Lumen Gentium, Vittorio Subilia observes that Biblicism and the universal priesthood of believers, characteristic aspects of Protestant Eaith, were integrated into the Roman Catholic Church. The same happened with elements of the Enlightenment such as "the value of conscience and personal rights, liberal respect for other people's convictions, and the recognition of religious, ideological and ethnic pluralism." Then Subilia makes a projection of what could happen in the future; he says, "Perhaps tomorrow it [Roman Catholicism] will take in elements of Marxist sociology." Vittorio Subilia, "The Ecclesiology of Vatican II," RefPW 28 (1965): 203.

-"The Christian who neglects his temporal duties neglects his duties toward his neighbor and even God, and jeopardizes his eternal salvation." "Pastoral Constitution on the Church in the Modern World," art. 43 (Abbott, 243).

Gustavo Gutiérrez defines Marxism as a science of history, which as such can perfectly coexist with Christian faith. To him, Marxism is "an analysis of society to transform it, an analysis oriented to transformation." "Marxismo-Cristianismo" [Text of a lecture at the Centro Crítico Universitario (CECRUN)], ed. and pub. CECRUN (Mexico D.F., Mexico: CECRUM, 1971), 9. See also idem, A Theology, 9-10, 29-30. For a discussion on Gutiérrez's Marxist analysis see his book The Truth Shall Make You Free, 53-84. 
Three years after the close of the council, in 1968, the Second Conference of the Latin American Bishops (CELAM) met in Medellin, Colombia.: Attempting to interpret Vatican I from a Latin American perspective, the bishops produced, in the process, what many regard as the initial document of Iiberation theology:" While vatican II focused on the

CELAM's meeting in Medellin had great significance for Latin American Catholicism. Dussel (History and the Theology of Liberation, 113) considers it as "the Vatican II of Latin America," because this Conference "gave concrete form and application to Vatican II." CE. orlando E. Costas, Theology of the Crossroads in Contemporary Latin America (Amsterdam: Rodopi, 1976), 69-72. Medeliin called the attention of Roman Catholics to the human injustice and oppression existing in Latin America and gave direction to the church in confronting the sociopolitical problems of the region.

Candelaria, Popular Religion and Liberation, 19; Comblin, "The Church in Latin America," 8. See also Prien, La historia del cristianismo en América Latina, 863-71. According to oliveros (Liberación y teología, 115-16), the participants at Medellin followed some of the methods used at Vatican II, especially in Gaudium et Spes. Thus, they began with a description and analysis of the Latin American reality, and then they reflected on this theologically. Although Alfonso López-Trujillo (De Medellín a Puebla [Madrid: Biblioteca de Autores Cristianos, 1980], 226-36) acknowledges that indeed Medelin started with reality, he does not believe that the bishops insisted that theology should be done from a sociopolitical analysis, but from a faith basis. Ricardo Durand (La utopía de la liberación [Callao, Perú: Arzobispado del Callao, 1988], 24-25), from the same point of view, adds that in the Medelinn documents the bishops were united in the option for the poor and the need for Iiberation in Christ, but without any mix of Marxism or Rationalism. According to Durand, it is the use of Marxist analysis in liberation theology that has divided the church, not only in Latin America but in the Third World as whole. Moreover, José Luis Illanes ("Teología de la liberación: análisis de su método," ScriptaTh 17 [1985]: $770)$ remarks that the bishops at the Medelin Conference described the church as centered in the otherworldiy 
church, Medeliin, in contrast, was more particularly concerned with the Latin American society. Its documents demanded a radical change within the Roman Catholic Church in this part of the world in order to meet the needs of lower-class society. As Gutiérrez notes, "Medelín provides guidelines for a transformation of the Church in terms of its presence on a continent of misery and injustice.":

One of the most important contributions of the Medellin Conference was its emphasis on the necessity of liberation.- Its participants discovered the poor and took

liberation rather than in the political liberation. On the other hand, the Medellin conclusions are perceived by liberation theologians as a commitment not only to church renewal but also to alleviate the problems of the Latin American poor. Some even suggest that in the documents of Medellin, Latin American bishops stressed the point that human liberation must involve all man's "dimensions--social, personal, national." Ferm, "South American Liberation Theology," 476. See also Illanes, "Teología de la Iiberación," 769-7I. For an analysis of Medelín's final conclusions, see Oliveros, Liberación y teologia, 113-35; Edward R. Killeckey, "The Medellin Guidelines," Afer 13 (1971) : 25-32; Donal Dorr, Option for the Poor (Maryknoll, NY: Orbis, 1983), 157-162; David Abalos, "The Medellin Conference," Crosscur 19 (1969): 113-32.

Gutiérrez, A Theology, 134. Donal Dorx, from the same point of view, states that the Medelin documents "became the charter for those who were working for a radical renewal of the Church in Latin America." Dorr, Option for the Poor, 158. See also R. McAfee Brown, Theology in a New Key (Philadelphia: Westminster, 1978), 52-55.

- As a reaction to the concept of development which "sought gradual change without the disruption of present institutions," Erancis P. Fiorenza observes: "The call for liberation was a demand for radical change." "Latin American Liberation Theology," Int 28 (1974): 444. 
sides with them. The option for the poor meant that bishops should take as theirs the problems and struggles of the poor: By opting for the poor, they attempted to break with a long history in which the Roman Catholic Church had been traditionally allied to the oligarchic political systems which had subjugated and kept the people oppressed and poor for centuries. By opting for the poor, Medeliin expressed a new ecclesial awareness of the Latin American problems and looked for new ways in which the church could be an instrument for their solutions. Thus, in the Medellin documents, the notion of an ideal society, characterized by justice and equality, found itself increasingly emphasized.

As a consequence, Latin American liberation

theologians have become more aware of the responsibility that the Roman Catholic Church shares for the status of

'Dorr, Option for the Poor, 176. In the Medellin documents, the bishops acknowledged their responsibility of being in solidarity with the poor. Dorr points out that "this solidarity is made concrete through criticism of injustice and oppression" (ibid., 159). One of the consequences of opting for the poor is the separation of the church from its links with the existing governments and ruling classes, rupturing the existing sociopolitical structures. See Abalos, "The Medellin Conference," 115.

- See National Conference of Catholic Bishops, The Church in the Present-Day Transformation of Latin America in the Light of the Council: Conclusiones (Washington, DC: Division for Latin America - USCC, 1973), 36-37, 42, 162-71 (this work will hereafter be cited as Medellín); Oliveros, Liberación y teologia, 122-24, 128. Cf. Eric J. Sharpe, "The Kingdom of God," in A New Dictionary of Christian Theology (1989), 318; Moltmann, Theology of Hope, 216-24, 325-29. 
dependency, poverty, and underdevelopment in Latin America.

They have undertaken the task of promoting the struggle against this present situation because they see the union of the church with the existing governments and ruling classes as a hindrance to Iiberate Latin Americans from the bondage of oppression and misery. They contest the views of those who encourage people to wait and look for a radiant future while patiently enduring present evils. Likewise, they insist "on linking all talk about God's future kingdom to working for proximate realizations of that kingdom now in history." :

Though they accept the idea that God's perfect Kingdom belongs to the future, the emphasis on the Kingdom as being built here and now is common to most of them. Thus, Segundo Galilea notes that the kingdom "is not exclusively reserved for the after-Iife but also anticipated on earth.":

Marc Kolden, "On Speaking of the Kingdom Today," WW 2 (1982): 155. Paraphrasing Marx and liberation theologians, Kolden states that "the task of eschatology is not to understand the world but to change it in the direction of the promised future" (ibid.).

-See Gutiérrez, A Theology, 177, 231; Leonardo Boff, Faith on the Edge: Religion and Marginalized Existence, trans. Robert R. Barr (New York: Harper \& Row, 1989), $170-$ 71.

'Segundo Galilea, "The Theology of Liberation," Lumvit 33 (1978): 344 . Cf. Jon Sobrino, Christology at the Crossroads, trans. John Drury (Maryknoll, NY: Orbis Books, 1978), 27; José Míguez-Bonino, Doing Theology in a 
The rereading of the gospel from the perspective of the poor radically changed the focus' of the debate about God's Kingdom and its significance. Gustavo Gutiérrez and the Iiberation theology movement as a whole have attempted to reverse the traditional emphasis on its transcendence." In tones reminiscent of Marxism, Gutiérrez calls men and women to create their own history and to be workers of their destiny.

Before reviewing Gutiérrez's concept of the Kingdom of God, the salient elements of his methodology are briefly considered.

Revolutionary Situation (Philadelphia: Fortress Press, 1975), 150-52; L. Boff, Faith on the Edge, 169-73; Clodovis Boff, Theology and Praxis, trans. Robert R. Barr (Maryknoll, NY: Orbis Books, 1987), 203-4.

Pernia, God's Kingdom and Human Liberation, 2, 22. Pernia suggests that prior to the liberation theology movement there were "two fairly distinguishable but closely related focuses. . namely the kingdom as concept, and the kingdom as symbol," and that this movement has made a specific contribution by providing another focus: the kingdom and liberation (ibid., 7, 21, 27).

-Gutiérrez, A Theology, 159, 167-68, 176-78. According to Methodist José Miguez-Bonino (Doing Theology, 151-52), the emphases of the kingdom as being present and yet future are not mutually exclusive but have to be held in tension.

Gutiérrez, A Theology, 29, 36, 232-39. Gutiérrez does not rule out the hope of the hereafter by emphasizing the present reality. He attempts to present the hope in the future consummation not as a promotion of pious escapism but of historical engagement. Cf. ibid., 231-32, 298-99. 
Gustavo Gutiérrez: The Theologian

Gutiérrez's theology did not develop in a vacuum. As Peter Riga states: "A theologian is in many respects a product of his time, and his speculations are tempered by the milieu in which he lives.": This statement can be validly applied to Gutiérrez for his theology grew out of the experience of the poor in Latin America, particularly in Peru, as the poor and oppressed struggled to relate the gospel to their labor for socioeconomic and political justice.

\section{Biographical Survey}

Gustavo Gutiérrez Merino was born on June 8, 1928, in Lima, Peru. From his childhood he knew what it meant to be poor, because he grew up in a family of very limited economic means. As a child, he spent six years in bed with osteomyelitis, which left him with a permanent limp. While a young man, he enrolled in the school of medicine at the national university of San Marcos in Lima, but after four years of university study he switched to philosophical and theological studies in order to prepare himself for the priesthood.

:Peter Riga, "The Ecclesiology of Johann Adam Möhler," TS 22 (1961): 565.

-Brown, Gustavo Gutiérrez, 20-28. Additional biographical details on Gutiérrez may be found in the following: William M. Ramsay, Four Modern Prophets (Atlanta: John Knox Press, 1986), 52-58; Rosino Gibellini, ed., 
After several years of study in Europe,: Gutiérrez returned to Peru in 1960 and, except for occasional short periods in which he lectured at various universities, he has remained in Lima. He works as a diocesan priest for a poor parish in Rimac, an historic section of Lima. He also teaches as a part-time professor in the Humanities Department at the Catholic University of Lima and has been for many years advisor to the Unión Nacional de Estudiantes Católicos (UNEC), a national organization of Catholic students.:

Based on his own experience as a university student and on his work as an advisor to UNEC, Gutiérrez looked for ways to relate university students' religious beliefs with

Frontiers of Theology in Latin America, trans. John Drury (Maryknol1, NY: Orbis, 1979), 311-13; Bacik, Contemporary Theologians, 165-77; Spinella, "An Evaluation of the Theology of Liberation as Presented by Gustavo Gutierrez," $12-35$.

'From 1951 to 1955 Gutiérrez studied philosophy and psychology at the University of Louvain. From 1955 to 1959 he studied in the theological faculty of the Catholic Institute of Lyons (France). In 1959 he was ordained a priest in Lima, then he spent one semester at the Gregorian University in Rome (1960). Gibellini, Frontiers of Theology in Latin America, 311-12. While attending the University of Louvain, he began his close friendship with Camilo Torres, who years lacer renounced his clerical responsibilities to join a colombian guerrilla movement and was killed on February 1966. Gutiérrez says of Torres, "He helped me see many things." "Gustavo Gutierrez: Liberation Theologian," Onew $8(1975): 13$.

-For a more detailed account of Gutiérrez's various responsibilities, see Brown, Gustavo Gutiérrez, 20-21. 
political activism. He is convinced that the Word of God has great political effectiveness, : and he does not believe that "announcing the Gospel and being political are two separate activities."

The chief work of Gutiérrez and that which has brought him the most fame is his A Theology of Liberation,

"Mi convicción es que la Palabra que el señor nos dice es de eficacia politica muy grande. Creo que ahi hay una aportación en esa vivencia, que la fe puede $y$ debe dar." Gutiérrez, "Marxismo-Cristianismo," 14.

-Martin A. Lee and Pia Gallegos, "Gustavo Gutierrez: With the Poor," ChrCris 47 (1987): 114. Joseph D. Spinella ("An Evaluation of the Theology of Liberation," 23-24) points out that Gutiérrez's life was influenced by his classmate Camilo Torres (see p. 58, n. 2 above) and José Carlos Mariátegui, a Peruvian Marxist analyst who wrote a collection of seven essays (José Carlos Mariátegui, Seven Interpretative Essays on Peruvian Reality, trans. Marjory Urquidi [Austin: University of Texas Press, 1971]) on Peru's socioeconomic and religious realities. Gutiérrez himself acknowledges that it was his pastoral work with students and certain popular groups which made him see the importance of Mariategui. He says, "The thought of Mariategui is very important for the awakening of a Peruvian self-

consciousness." "Gustavo Gutierrez: Liberation Theologian," 13. It should be added, however, that Gutiérrez was also influenced by the writings of Bartolome de las Casas (14741566), who identified with and struggled for the Indians, demanding social justice in the process of colonization and evangelization in the new land. Las Casas has been referred to as a precursor of the twentieth-century liberation theology. See Enrique Dussel, "The Political and Ecclesial Context of Liberation Theology in Latin America," in The Emergent Gospel, ed. Sergio Torres and Virginia Fabella (Maryknoll, NY: Orbis, 1976), 180. See also Gustavo Gutiérrez, Las Casas: In Search of the Poor of Jesus Christ, trans. Robert R. Barr (Maryknoll, NY: Orbis, 1993).

'Gutiérrez's original work in Spanish [Teología de la Iiberación] was published 1971. The English edition appeared two years later. Since then it has been translated into several Ianguages. 
considered the classic presentation of the theology of Iiberation: According to osvaldo I. Mottesi, Gutiérrez's book has produced an enormous impact not only in Latin America but well beyond its borders. It can be considered an indispensable reference for studying the theology of Iiberation.:

\section{Gutiérrez's Methodology and Hermeneutics}

Since the beginning of his theological enterprise, Gutiérrez has pointed out that the importance of the theology of liberation is not found in its content, but in the whole new way of doing theology.' Even though he refers

Gibellini, Frontiers of Theology, 312. What is found in Gutiérrez's theology of liberation in the opinion of Deane W. Ferm (Third World Theologies: An Introductory Survey [Maryknoll, NY: Orbis, 1986], 17) is an answer to the proper role of theology and of the theologian in the attempt to be faithful both to the Christian gospel and to the poor of Latin America. Pierre Hegy concurs, adding that Gutiérrez's work is a synthesis between otherworldiliness and involvement in this world (Review of $A$ Theology of Liberation, by G. Gutiérrez, JSSR 13 [1974]: 243). Likewise, Osvaldo D. Santagada points out that Gutiérrez's book is an attempt to dialogue between Christians and Marxists (Review of Teología de la liberación: Perspectiva, by G. Gutiérrez, Cuadernost 3 [1973]: 98).

-Mottesi, "An Historically Mediated 'Pastoral' of Liberation," 120-21.

'Gutiérrez, A Theology, 15. Xosé Miguélez, La teología de la liberación y su método (Barcelona: Herder, 1976), 13, 84-89, defines the method of liberation theology as "critical-dialectical." Gutiérrez devotes the first part of his A Theology (pp. 3-19) to the clarification of his methodology which is intended, as Alfred $T$. Hennelly, "Theological Method: The Southern Exposure," TS 38 (1977): 
to his method as "new," he also states that it "has its roots in the first centuries of the Church's life." Gutiérrez sees Augustine's City of God as an example:

The primary task of theology, as he sees it, is the liberation of the oppressed from their inhuman living conditions. Theology must respond to the conditions in which human beings live. It must "be part of the process through which the world is transformed." = Thus Gutiérrez's methodology departs from the traditional deductive reasoning which has characterized the Roman Catholic Church and presents itself as a critical reflection on praxis in the light of faith.

714, remarks, for both academic theologians and those who try to lead the Christian life.

'Gutiérrez, A Theology, 6. Gutiérrez suggests an approach to theology drawn from Augustine who attempted to relate the Christian faith to the everyday problems and struggles in Christians' Iives.

Ibid., 15.

According to Gutiérrez, "Theology is an expression of the awareness that a Christian community has of its faith at a given moment in history. This moment, dated and sealed, is a locus theologicus of the first importance. For theology is an attempt to do a reading of the faith from a point of departure in a determined situation, from an insertion and involvement in history, from a particular manner of living our encounter with the Lord in our encounter with others" (The Power of the Poor in History, 36-37). A further examination of the methodology of Latin American liberation theology in general may be found in Miguélez, La teología de la liberación y su método; Manzanera, Teología, salvación y liberación; Roger Haight, An Alternative Vision: An Interpretation of Liberation Theology (Mahwah, NJ: Paulist Press, 1985), 43-63; Hennelly, 
Whereas modern theology has taken as its point of departure the unbelieving mind, Gutiérrez's mode of theologizing is a deliberate attempt to critically reflect on God's word "from the underside of history," from the perspective of "those systematically and lawfully stripped of their human status, those who hardly know what a human being is.": The starting point for Gutiérrez's theology is the poor: His concern is not how to speak of God in a

"Theological Method: The Southern Exposure," 709-35; Octavio Ruiz, "La teología de la liberación y su método," Me 14 (March 1988): 41-64; Illanes, "Teología de la Iiberación: análisis de su método," 743-88.

:Gutiérrez, The Truth, 7. Victorio Araya, God of the Poor, trans. Robert R. Barr (Maryknoll, NY: Orbis, 1987), 20, defines liberation theology not as a theology of or for the poor, but as "a theology set in motion from a point of departure in the poor, the poor as interlocutor, as historical subject" (italics in the original). See also Gutiérrez, The Power of the Poor, 93-94, 193.

-For Gutiérrez (The Power of the Poor, 92, 193), the term "poor" or "nonperson" designates those persons who are considered "less than human by society." It denotes classless, powerless, and economically oppressed and exploited human beings. Furthermore, he perceives poverty as the "product, or byproduct, of an economical and social system fashioned by a few for their own benefit" (Gustavo Gutiérrez, "The Irruption of the Poor in Latin America and the Christian Communities of the Common People," in The Challenge of Basic Christian Communities, trans. John Drury. ed. Sergio Torres and John Eagleson [Maryknoll, NY: Orbis, 1981], 111. Cf. idem, A Theology, 26). Therefore, Gutiérrez considers the social science a significant tool to better understand the social condition of Latin America and the mechanisms of a capitalist society. See idem, The Truth, 11-12; idem, The Power of the Poor, 47 . For a treatment of the concept of the poor in Iiberation theology, see Rodor, "The Concept of the Poor in the Context of the Ecclesiology of Liberation Theology." 
world come of age, but how to proclaim God as Father in a nonhuman world.

The irruption of the poor in history, according to Gutiérrez, is the most important event in the recent history of Latin America.: He insists, therefore, that history and the gospel must be re-read from the viewpoint of the poor. Even the church itself must rethink itself from the position of the poor in order to be faithful to God." Gutiérrez's

Gutiérrez, The Truth, 7. Like Gutiérrez, who makes a comparative analysis of the European and the Latin American theological approaches, Jon Sobrino also finds correlative differences between the two. While the former is a dialogue with the tradition of thought, the latter is a confrontation with present reality. European theology helps the believer to live with the reality of hunger, whereas Latin American theology helps the believer to overcome hunger. The language used for European theology is predominantly philosophical; Latin American language is more social-scientific. While European theology tends to leave reality itself untouched and, thus, supports the status quo, Latin American liberation theologians seek the transformation of reality. Jon Sobrino, "El Conocimiento Teológico en la Teología Europea y Latinoamericana," EstCent $30(1975): 431-34$.

-Gutiérrez, "The Irruption of the Poor," 108. The poor are regarded as nonpersons who are forcing their presence in history. This implies and demands the necessity that theological reflection be done from their perspective, while seeking their liberation. See Gutiérrez, The Power of the Poor, 169-221; Gustavo Gutiérrez and Richard Schaull, Liberation and Change (Atlanta: John knox Press, 1977), 9293.

"Gustavo Gutiérrez, "The Poor in the Church," in The Poor and the Church, ed. Norbert Greinacher and Alois Müller (New York: Seabury Press, 1977), 13-15. Gutiérrez holds that theology degenerates into "academic exercise" if the poor are not considered the historical subject of a concrete praxis: "the liberation praxis of the oppressed." Gustavo Gutiérrez, "Two Theological Perspectives: Liberation 
concern is that the gospel be in the hands of the poor because "the sign of the arrival of the Kingdom is that the poor have the gospel preached to them.": Moreover, he perceives the arrival of the Spanish conquerors in the sixteenth century to be the cataclysm which turned the Latin American world upside down, oppressing the Indians." This situation needs to be reversed, and the church through base ecclesial communities must play a determinant role in the construction of a different society." Thus theology,

Theology and Progressivist Theology," in The Emergent Gospel, ed. Sergio Torres and Virginia Fabella (Maryknoll, NY: Orbis, 1976), 247.

Gutiérrez, "The poor in the Church," 15. Gutiérrez expresses this same idea in Liberation and Change: "The reintegration of God in history takes place when the poor of the land produce a social appropriation of the gospel, when they expropriate the gospel from those who consider themselves its privileged owners. The gospel telis us that the sign that the kingdom has come is that the poor are evangelized." Gutiêrrez and Schaull, Liberation and Change, 93.

Gutiérrez, "The Irruption of the Poor," 112.

For Gutiérrez these base ecclesial communities are a tool for the evangelization of all nations from the perspective of the poor. He says that only these communities "will be in a position to proclaim and live the values of the kingdom in the very midst of the common masses who are fighting for their liberation" ("Irruption of the Poor in Latin America," 118). Because the poor live in a condition of oppression, they are not only hearers but privileged bearers of the gospel (see Gustavo Gutiérrez, "Statement by Gustavo Gutiérrez," in Theology in the Americas, ed. Sergio Torres and John Eagleson [Maryknoll, NY: Orbis, 1976], 311). See also Enrique Dussel, "The Kingdom of God and the Poor," IntRMiss 69 (1979): 124; L. Boff, Faith on Edge, 172. "They alone are capable, by reason of their lived participation in the struggle," 
Gutiérrez argues, must begin from the experience of the poor and seek an alliance with them in order to create a new human being.

The very life of the church, in Gutiérrez's thought, "is a privileged locus theologicus for the understanding of the faith.": At the same time, theology must be open to the totality of human history and "go beyond the visible boundaries of the Church," because, for Gutiérrez,

Michael L. Cook comments, "to apprehend and articulate the true meaning of the kingdom of God," because it can only be articulated through concrete, historical transformation "from below." Michael L. Cook, "Jesus from the Other Side of History: Christology in Latin America," TS 44 (1983): 259 .

'Gutiérrez, A Theology, 32, 146. Gutiérrez conceives theology as the result of reflecting on the response of the poor to their oppressive situation. See idem, The Power of the Poor, 60. Thus, the liberation praxis is the starting point of the reflection of faith rather than the revelation in the scriptures.

-Gutiérrez, A Theology, 8, 12. This life of the church emphasizes the participation of Christians in the process of liberation, which Gutiérrez considers an "outstanding phenomenon of our time" (ibid., 14, 49), and the starting point for theological reflection (ibid., 43, 143).

Ibid.. 12. In this reasoning, Gutiérrez follows Yves Congar who asserted that if the church wants to deal with the real problems of the modern world and indeed it attempts to respond to them, then, "it must start with facts and questions derived from the world and from history" rather than using only revelation and tradition (Yves Congar, quoted in Gutiérrez, A Theology, 12). In this opening to the totality of human history, Gutierrez believes theology can fulfill its critical function without narrowness (ibid.). 
liberation is not only the Christian's work, but the work of men and women in general, regardless of their faith.:

Theology can run the risk of being static and sterile, Gutiérrez notes, if it is based only in "'truths' which have been established once and for all." To avoid this, theology must include the "Truth which is also the Way." Hence, it is not enough for the church to denounce verbally the dehumanizing situation in Latin America; it must also take a stand and act according to "a truth which is done." :

In Gutiérrez's thought, then, theology operates out of a prior active commitment to the poor. It does not start from theological categories but from "faith which works

Ibid., 72. Gutiérrez seems to have in mind Gaudium et Spes which states, "In fidelity to conscience, Christians are joined with the rest of men in the search for the truth, and for the genuine solution to the numerous problems which arise in the life of individuals and from social relationship." Second Vatican Council, "Pastoral Constitution on the Church in the Modern World, "art. 16 (Abbott, 214).

-Gutiérrez, A Theology, 13.

Ibid., 268. The faith in God leads Christians to a commitment and action in the struggle for justice; this is, for Gutiérrez, "to do the truth" (ibid., 10). In Gutiérrez's words: "Reflecting on faith as liberation praxis means reflecting on a truth that is not just affirmed but concretely fashioned. . . . It is in deeds, not simply in affirmations, that we salvage our understanding of the faith from all forms of idealism." Gustavo Gutiérrez, "Liberation Praxis and Christian Faith," in Frontiers of Theology in Latin America, ed. Rosino Gibellini, trans. John Drury (Maryknoll, NY: Orbis, 1979), 22. 
through charity." for theology is a second step; it reflects upon the pastoral activity of the church.: Gutiérrez emphasizes that the love to God and neighbor is manifested in concrete actions where "doing" has predominance over "knowing." ${ }^{3}$ As a result, human action--as the point of departure for all reflection--is the key for understanding Gutiérrez's theology.

Since the socioeconomic and political reality of Latin America serves as the starting point for critical reflection, what shall be the role of the scriptures in Gutiérrez's theology?' As already noted, the Peruvian theologian defines theology as "a critical reflection on Christian praxis in the light of the Word,"s accepted in faith. The word accepted in faith does not mean that Christians have to accept "only truths which have been

Gutiérrez, A Theology, 11. See also idem, "Two Theological Perspectives," 247; idem, "Faith as Freedom: Solidarity with the Alienated and Confidence in the Future." Horizons 2 (1975): 48 .

-Gutiérrez. A Theology, 11.

Ibid.. 298.

An analysis of liberation hermeneutics is found in Steven Phillips, "The Use of Scripture in Liberation Theologies: An Examination of Juan Luis Segundo, James H. Cone, and Jürgen Moltmann" (Ph.D. diss., The Southern Baptist Theological Seminary, 1978).

Gutiérrez, A Theology, 13 ; see also 43 .

Ibid., 79; see also 145. For Gutiérrez, the expression "in the light of the Word" is synonymous with "in the light of Eaith" (ibid., 144). 
established once and for all.": According to our author. the word of God is "word and happening, both at the same time."- Consequently, based on "the word accepted in faith," Gutiérrez sees the necessity for Christians to be actively involved in the task of transforming society as a result of their "conviction of the radical incompatibility of evangelical demands with an unjust and alienating society."

The scriptures, therefore, as well as tradition, are witnesses to the truth of praxis rather than sources of truth. More explicit than Gutiérrez regarding the use of the Scriptures in Iiberation theology, Hugo Assmann;

\section{Ibid., 13.}

-Gutiérrez, The Power of the Poor, 5. Gutiérrez believes in a God who acts, speaks and makes himself known in his works in history (ibid.).

Gutiérrez, A Theology, 145. "Because of the word accepted in faith," Gutiérrez states, "we see that the fundamental obstacle to the Kingdom, which is sin, is also the root of all misery and injustice; we see that the very meaning of the growth of the Kingdom is also the ultimate precondition for a just society and a new man" (ibid., 176). In Gutiérrez's thought it is clear that Christians "cannot claim to be Christians without a commitment to liberation" (idem, The Power of the Poor, 145). The participation in the struggles of the poor and oppressed affects the way in which one does theology and interprets the scriptures. "Only by participating in their struggles," Gutiérrez holds, "can we understand the implications of the message and make it have an impact on history" (idem, A Theology, 269).

'Hugo Assmann was born in Brazil (1933). He studied philosophy and sociology in Brazil, and theology in Rome. He is considered the apologist of the liberation theology movement (Orlando Costas, The Church and Its Mission: Shattering Critique from the Third world [Wheaton, IL: 
maintains that today God's word grows from the process of historical awareness, analysis, and involvement rather than from propositions. He also considers the scriptures and tradition as a basic reference about how God spoke in the past so that today individuals might be helped to see God speaking in their own situations. But these words do not speak directly to the conditions of the modern man and woman. They are "no longer a fixed absolute, an eternal proposition we receive before analyzing social conflicts and before committing ourselves to the transformation of historical reality.":

\section{Summary}

From the preceding survey it can be seen that from Augustine to the second Vatican Council the Roman Catholic Church has mainly understood itself as the representation of the transcendent and perfect Kingdom of God on earth. This strong tradition led Roman Catholicism to a triumphalist and ecclesiocentric attitude in which there was no room for either criticism or needed substantial reform.

Tyndale House, 1974), 223).

'Hugo Assmann, "Statement by Hugo Assmann," in Theology in the Americas, ed. Sergio Torres and John Eagleson (Maryknoll, NY: Orbis, 1976), 299. In the words of Thomas Bokenkotter, liberation theologians believe that "the Word of God does not come to us primarily from the Bible or the Church, but is heard in the cry of the exploited and marginalized poor" (Essential Catholicism [New York:

Doubleday, 1986], 37). 
The Second Vatican Council, however, has been a turning point. It attempted a change in the church's understanding of its nature by deemphasizing the institutional model in favor of a more moderate ecclesiology. At the same time, it opened the door to include temporal affairs into Christian faith. These two aspects, especially the concern for social issues, quickened Latin American theologians to develop a theology to meet the need of the suffering people of the region.

On the other hand, the council dealt with the notion of the Kingdom of God from the perspective of the church. Although the attempt was made to understand the church as subordinated to the notion of the Kingdom, in the end, the Kingdom seems to be understood as being subordinated to Vatican II's understanding of the nature of the church. The renewal of Roman Catholicism promoted by Vatican II reaped some of its first fruits in Latin America at the meetings of CELAM in Medellin where the Latin American bishops opted in favor of the poor. This new perspective prepared the way for the development of the liberation theology movement and its reinterpretation of the notion of the Kingdom of God within Roman Catholicism. Gustavo Gutiérrez, a first-hand witness of the reality of poverty and misery in Latin America, went beyond the original intention of Medellin and challenged European theology by 
taking the irruption of the poor as the basic experience of

Christians for doing theological reflection.

Within this context, how does Gutiérrez understand

God's Kingdom? This is the subject considered in chapter 3. 
CHAPTER III

\section{GUSTAVO GUTIÉRREZ'S UNDERSTANDING OF THE KINGDOM OF GOD}

Prior to the second Vatican Council, it was generally held in Roman Catholic circles that the prime task of the church was to proclaim the gospel, perceived primarily as spiritual in nature and separated from the material order. Vatican II made possible a shift in Roman Catholic thinking with regard to social justice, now considered part of the gospel.

In Latin America, Gustavo Gutiérrez and most Iiberation theologians made a major effort to call attention to the promotion of social justice along the lines suggested by the Council. In the process, Gutiérrez distinguished "orthodoxy"--a traditional interpretation and exposition of the Scriptures--Exom "orthopraxis," which encourages the poor and oppressed to struggle for justice in a new social order: His preference for orthopraxis not only affected

:A Theology, 10. The knowledge of God, as believed by Gutiérrez, "is tested on the terrain of actual practice" (The Power of the Poor, 9). All works in this chapter are by Gustavo Gutiérrez unless otherwise indicated. 
Rereading the gospel from the perspective of the poor led Gutiérrez to reinterpret Christian doctrines, emphasizing the temporal reality more than the transcendental. From this perspective his understanding of the Kingdom of God appears subversive because it calls for an end to all exploitation. This chapter undertakes a systematic presentation of Gutiérrez's understanding of the kingdom. The first section of this chapter outlines briefly the different models of pastoral theology present in Latin America and their relationship to the notion of the Kingdom. Next, it deals with the language and the meaning of the Kingdom in Gutiérrez's thought. Thirdly, the Kingdom as gift and task as well as its historical and eschatological dimensions are examined. Finally, this chapter surveys the relationship between the Kingdom and the church.

\section{The Relationshio between the Kingdom of God and Temporal Reality}

As an advisor to groups of university students and being politically committed to justice in society, Gutiérrez's main concern was the relationship between Christian faith and political commitment--in other words, the relationship between the church and the world: This

Gutiérrez perceives the relationship between the church and the world as essential in the theological perspective of the pastoral in the Latin American church. "Si tuviéramos que definir lo esencial de la perspectiva teológica de este estudio, diríamos que su punto de vista es el de las relaciones de la iglesia con el mundo" (Líneas 
relationship between faith and temporal reality, or "between the kingdom of God and the building up of the world": is referred to as a classical question in theology. Gutiérrez distinguishes four different responses to this relationship: "Christendom," "New Christendom," "the distinction of planes," and the "prophetic" approach." Each of these is based on the church's understanding of its mission to announce the Kingdom of God and salvation to the world. These approaches may overlap; according to Gutiérrez, they are not necessarily exclusive and, therefore, may coexist in Latin America.

The Christendom mentality, for Gutiérrez, prevailed in Roman Catholicism from the time of Augustine to the midtwentieth century." This pastoral outlook survived in Latin America longer than elsewhere due to Spain's influence, which led to the prolongation of the Middle Ages in the New

pastorales de Ia Iglesia en América Latina, 5th ed. [Lima: CEP, 1979], 8. This work is a reedition of La pastoral en Ia Iglesia en América Latina [Montevideo: Ediciones del Centro de Documentación MIEC-JECI, 1968]).

A Theology, 45.

-An overall view of these four approaches and their respective theological analysis can be found in Lineas pastorales, 13-84. CE. A Theology, 53-77.

See Lineas pastorales, 14-21, 33-39; A Theology, 53-54. Gutiérrez is aware that Christendom mentality is still influential in important sectors of the Roman Catholic Church, and this is the cause of the opposition to any change in Roman Catholicism today (ibid., 54). 
World.: This approach regards the church as the sole depository of salvation and, therefore, a powerful social force. - All this calls for a direct intervention of the church in political affairs and a lack of autonomy for the temporal order. From this perspective, Gutiérrez sees no room for a profane, historical plan in the realization of the Kingdom of God." This approach led to a marked ecclesiocentrism in which the Roman Catholic Church is perceived as the only way to salvation and the representative of the Kingdom of God on earth."

The New Christendom pastoral mode allows for a relative autonomy of the temporal sphere, while the church continues to be at the center of the work of salvation. Even though this model makes a clear distinction between temporal and spiritual, as well as between the tasks of laity and clergy, the church still intervenes indirectly in the world, promoting institutions inspired by Christian principles, such as Christian schools and democratic parties. This is perceived as the church's attempt to incarnate the gospel in the culture of a particular society.

See above pp. 43-48.

A Theology, 53 .

Ibid.

isee Iineas pastorales, 59. $40-49$

A Theology, 55. See also Lineas pastorales, 21-27; 
Gutiérrez considers this pastoral model incapable of bringing about a radical social transformation.

The "distinction of planes," also referred to as "mature faith," - allows the Christian laity to exercise its political responsibilities with greater independence from ecclesiastical authority. It recognizes that the world has a functional autonomy and a role different from that of the church within God's plan of salvation. Since the world is autonomous, the church is not responsible for constructing it. The Roman Catholic Church is not to intervene in temporal matters, except through moral teachings, and its mission is perceived as evangelization and inspiration of the temporal sphere.

Since the planes are clearly differentiated, how then is the relationship between the church and the world within the unity of God's plan? According to Gutierrez, the church and the world find their unity in the notion of the Kingdom of God. It unifies them and they contribute to its edification. This approach, nonetheless, rejects not only

A Theology, 56-58. In Latin America this approach did not affect the greater part of the church, Gutiérrez observes, but rather certain movements and pastoral circles. This is perceived in the strong bonds which tie the church to the present social order (ibid., 58).

- See Líneas pastorales, 27-29; 50-61.

'A Theology, 57. In this statement, Gutiérrez calls attention to Yves Congar's Lay People in the Church, rev. ed. trans. Donald Attwater (Westminster, MD: Newman Press, 1967), chap. 3. See also Lineas pastorales, 54. 
the idea that God's Kingdom can be established on earth but also the notion that the church, which is itinerant, can be established in the world and create God's Kingdom on earth." In his attempt to correct and deepen the "distinction of planes" approach, Gutiérrez developed a new "prophetic" pastoral.' He agrees that the laity should be autonomous in fulfilling its political responsibilities. However, he goes a step further and proposes that the church should break with and denounce the established unjust order." The gospel should be announced in such a way as to accomplish its conscienticizing role--in his words, its "politicizing function." One wonders whether it is possible for Christians to be free from ecclesiastical interference while carrying out their political function, and at the same time, for the church to exercise its

: "Por su rechazo a toda confusión de la iglesia con lo temporal, esta opción pastoral [Madurez en la Fe] es muy crítica frente a la idea de que el Reino de Dios pueda establecerse en la tierra. . . la Iglesia no podrá instalarse en el mundo $y$ crear un Reino de Dios en la tierra ya que es una Iglesia en camino, itinerante." Lineas pastorales, 59 .

- See Iineas pastorales, 29-32; 62-84. Under the present circumstances in which Latin Americans live, Gutiérrez sees the need for a theology in which the autonomy of the world and the unity of nature and the supernatural are established.

'See A Theology, 115, 267.

ibid. , 269. 
prophetic role in the world without overrunning the autonomy of the laity.

In brief, Gutiérrez's liberation theology promotes a shift of attention from the church and the otherworldly to this world. While in the Christendom mentality the center is the church, Gutiérrez's theology begins with the world as a locus theologicus.: Therefore, this "prophetic pastoral" led Gutiérrez to redefine his concept of salvation and to tend to identify salvation and the Kingdom of God.

\section{Salvation and Liberation}

The notion of salvation is central to Gutiérrez's thought.- He believes that any theological elaboration is

'In the past "the tendency was to see the world in terms of the Church," Gutierrez observes; today "the Church is seen in terms of the world" (A Theology, 67). It is the world, the Iiberation process in particular, that poses to the church the question of the meaning of salvation. See ibid., 149-52.

- He sees salvation as "a concept central to the Christian mystery" (A Theology, 149). He believes that the notion of salvation has not received a serious examination by theologians. To support this view, he quotes Congar's statement that the idea of salvation "has been left so vague" and is in urgent need "for an adequate elaboration" ("Christianisme et Libération de I'homme," Masses Ouvrières, no. 258 [December 1969], 8, cited in A Theology, 178, n. 1). Thus his main purpose in $A$ Theology of Liberation is to reexamine the meaning of salvation, especially in relation to the building of a just society. (See ibid., $x, 43,45$, 135, 149). Here Gutiérrez reinterprets the Christian doctrine of salvation, seeking to determine the salvific value of human beings' actions in history. He attempts to demonstrate a harmonious relationship between the liberation from sin offered by God in Christ and the liberation of all other oppressions achieved by human beings in history. 
rooted in the key notion of salvation: Because Gutiérrez believes that salvation is not something to be achieved in another world, but something that encompasses all dimensions of human existence, he claims to have recovered the notion of salvation as "an intrahistorical reality," one that transforms history, orienting and guiding it to its full realization.

In the development of his liberation theology, he tends to utilize the terms "salvation" and "liberation" as interchangeable concepts. He clearly states: "Liberation is another word for salvation." ${ }^{3}$ When human beings participate in the change of social structures, they necessarily participate in the salvific process, for as Gutiérrez explains, the transformation of this world is part of salvation:" The term "liberation" sums up the aspiration of

"Toda elaboración teológica parte de una noción clave: la salvación" (Lineas pastorales, 34). See also p. 41 .

-A Theology, 151-52.

"Terrorism, Liberation and Sexuality," The Witness (April 1977): 10. Solle observes that liberation theology has changed the traditional translation of the word soteria: salvation--"rescue, deliverance from danger of dying or from prison"--for liberation. Now, she says, Christ is described as liberator and his "message of the Kingdom of God is to be taken as a message about the construction of a world, in which justice and henceforth peace will be possible." Dorothee Sölle, "Resistance: Toward a First World Theology," ChrCris 39 (1979): 178 .

"A Theology, 159. The term "liberation" is used as the most adequate word to refer to God's saving acts in 
the Latin American poor to be free from their present yoke of socioeconomic, political, and cultural dependence and oppression, to which they have long been submitted.'

Gutiérrez maintains that Christendom as well as New Christendom pastorals worked under the assumption that salvation was possible only within the church: extra ecclesiam nulla salus.: Accordingly, the Kingdom of God was understood as a post-historical reality represented in history by the church. On the other hand, he sees in the distinction of planes a suggestion of the possibility of salvation outside the church. ${ }^{3}$ In this approach the Kingdom of God is also envisioned as a post-historical reality, but the church is no longer the locus of salvation.

In the prophetic model, he insists that since salvation is equally available to all human beings, whether

history. As Gutiérrez sees it, "the theology of liberation is a theology of salvation in the concrete historical and political circumstances of today" ("The Hope of Liberation," WorldV 17 [June 1974]: 37). Cf. "Liberation Movements and Theology," in Jesus Christ and Human Freedom, ed. Edward Schillebeeckx and Bas Van Iersel (New York: Herder and Herder, 1974), 145.

"Contestation in Latin America," in Contestation in the Church, ed. Teodoro Jiménez Urresti (New York: Herder and Herder, 1971), 43.

'See A Theology, 150.

'For Gutiérrez, the distinction of planes does not solve the problem of the salvation of atheists, and, therefore, it is a transitional period. See lineas Pastorales, 51-54. 
or not they belong to the Roman Catholic church, there must be a common requirement for it, namely love: Consequently, to encounter the Lord in the neighbor and to accept his salvation by loving him or her is a central element of Gutiérrez's theological system.

Moreover, based on the assumption that God's saving action embraces and transforms all human reality, Gutiérrez develops a tridimensional interpretation of the liberation process which first includes political liberation, followed by liberation of humanity throughout history, and ultimately liberation from sin." Since all three aspects are

Ibid., 64. "En la pastoral profética se afirmará que la condición de la salvación es el amor; la salvación es fruto del amor; se salva el que ama, es decir, entra en comunión con Dios el que entra en comunión con los hombres" (ibid., 64-65).

- See A Theology, 194-203. As Gutiérrez himself says: "one must go through man to reach God" (ibid., 206).

A Theology, 176. Cf. ibid., 36-37. Gutiérrez takes a dialectical approach to the three levels of liberation. He distinguishes them, not to separate or divide them, but in order to unite them (The Truth, 14, 12122). It is precisely the unity of these levels which in his eyes gives strength to his understanding of liberation. In regard to their order. Gutiérrez maintained, in an interview with James Nickoloff in June 1988, that he follows a "liturgical order" going from the least to the most important, i.e.. from social-economic-political liberation to liberation from sin (Nickoloff, "The Church and Human Liberation," 253, n. 64). Nonetheless critics observe in Gutiérrez's thought a priority for the political liberation over liberation from sin. Thus, Cardinal Joseph Ratzinger criticizes liberation theology in general, including Gutiérrez's theology, for placing more emphasis on "liberation from servitude of an earthly and temporal kind" and putting "liberation from $\sin$ in second place and so fail[ing] to give it the primary importance it is due" 
interdependent and affect each other, Gutiérrez claims that they must be considered together as part of a whole to avoid idealist or spiritualist approaches, as well as programs of short-term effect.: This threefold meaning of liberation allows him to interrelate God's grace and human action, and to define the kingdom as both a gift and a demand." It is obvious that in Gutiérrez's prophetic pastoral the Kingdom of God remains post-historical, yet with partial

(Congregation for the Doctrine of the Faith, "Instruction on Certain Aspects of the 'Theology of Liberation, " Or 14 [September 13, 1984]: 195). Likewise, the bishop of the Callao diocese in Lima, Ricardo Durand, Observaciones a Teología de la Liberación (Callao, Perú: LObispado del Callao], 1985), 130-34, observes that Gutiérrez deals with the theological aspect of liberation only after having discussed the socioeconomic and political liberation and its contribution to the formation of a new human being in a qualitatively different society. Deane Ferm (Third world Liberation Theologies, 18) notes that to do justice to Gutiérrez's use of the term liberation, "it is important that we interpret it with reference to all three meanings." He further argues that Gutiérrez does not receive a fair appraisal because his critics focus too much on the first meaning of liberation.

A Theology, 37. Some criticize Gutiérrez for having fallen in the trap of identifying salvation and social justice, which implies that by participating in political liberation, human beings are also liberating themselves from sin. In other words, they become their own savior. See David G. Kibble, "The Kingdom of God and Christian Politics," Thm 7 (September 1981): 25. The Roman "Instruction on Certain Aspects of the 'Theology of Liberation'" refers to the same problem as "a process of self-redemption of man by means of the class struggle" ("Instruction on Certain Aspects of the 'Theology of Liberation, " 201).

- See below pp. 98-106. 
realizations in history.' The question now arises: what is, then, the relationship between the Kingdom of God and salvation in Gutiérrez's theology?

The Kingdom of God and Salvation

Since salvation is perceived as a single yet complex process of liberation embracing all dimensions of human existence,- our author addresses first the social reality, the condition of the poor and oppressed, and then seeks an interpretation of the term "salvation" which agrees with that reality. He therefore can conclude that the transformation of this world, the struggle against misery and exploitation, and the building of a just society is a salvific work:" Even more, for Gutiérrez, the grace-sin conflict, the coming of the Kingdom, and the expectation of

A similar view is shared by Leonardo Boff: "The liberation a Christian is looking for is one that realizes, in history, the transhistorical notion of the Kingdom of God." Leonardo Boff and Clodovis Boff, Salvation and Liberation, trans. Robert R. Barr (Maryknoll, NY: Orbis Books, 1984), 75 .

-A Theology, 37, 235.

Ibid., 159. The connection between salvation and the process of liberation was developed at the Medeli in Conference. At its opening, the Cardinal Archbishop of Lima, Juan Landazuri Ricketts, emphasized that "in Latin America, salvation, which is the realization of the Kingdom of God, involves the liberation of all men, the progress of each and all from a less human condition to one more human." Catholic Church, Consejo Episcopal Latinoamericano, The Church in the Present-Day Transformation of Latin America in the Light of the Council: Position Papers (Washington, DC: U.S.C.C., 1973), 23. 
the parousia are also necessarily and unavoidably temporal realities.

The fact that the struggle to bring to an end misery and exploitation is salvific work does not mean that God's salvation and human progress are equated. Our author cautiously avoids any identification between the two. As he sees it salvation transcends human projects.: Because God's salvation embraces both personal liberation from sin as well as Iiberation from all kinds of exploitation, it is closely related to the kingdom where the communion of human beings with God and among themselves is lived. Gutiérrez holds that to abolish injustice and enjoy God's salvation necessitates the historical establishment of the kingdom of God. God's kingdom is a precondition for a just society. Still, our author remains cautious not to reduce both salvation and God's Kingdom to human progress.'

But there are a few instances that indicate that Gutiérrez implicitly equates the Kingdom with salvation. For example, in dealing with the relationship between salvation and the historical process of liberation, he writes:

We are dealing here with the classic question of the relation between Eaith and human existence, between

\footnotetext{
A Theology' 167.

Ibid., 177 .

Ibid.
} 
faith and social reality, between faith and political action, or in other words, between the Kingdom of God and the building up of the world.:

One may infer yet another implicit identification of the kingdom with salvation in his ecclesiology. The church is described as a sign or sacrament both of salvation and of the Kingdom." Gutiérrez writes: "The church is the sacrament of God's saving plan--that is, of the Kingdom."i Quite possibly with this very equation in mind, Gutiérrez declares the church to be the simultaneous sacrament of salvation and of the Kingdom, thereby alluding to their similitude.

In summary, Gutiérrez does not limit salvation to the strictly religious sphere. While affirming that salvation, integral liberation, encompasses all dimensions of human existence, he seems to give primacy to political Iiberation.

\section{The Language of the Kingdom of God}

Following the lead of the Roman Catholic official teaching, Gutiérrez does not define the phrase "Kingdom of

Ibid., 45 (emphasis supplied). Clodovis BofE likewise defines salvation as the Kingdom of God. See Boff and Boff, Salvation and Liberation. 76.

$$
\text { Ibid., } 261 .
$$
1986): 51 .

G. Gutiérrez, "Buscar el Reino," Pag 79 (setiembre

$$
\text { iThe Truth, } 144 .
$$


God" in concrete terms. The question may be asked, then, what does the Peruvian theologian have in mind when using the expresion "Kingdom of God"? For Gutiérrez to speak of the Kingdom of God is to speak of God Himself, as the Kingdom is inseparable from God. Thus, wherever the Kingdom is established, God is present; likewise, where His reign and demand to do justice are denied, He is absent." Any attempt to separate them is to turn God into an idol. resulting in idolatry.

The God of Life, trans. Matthew J. O'Connell (Maryknol1, NY: Orbis, 1991), 67. Gutiérrez echoes the assertion of the bishops at Puebla (n. 226) which stated that the Kingdom "is to be found in a certain way wherever God rules through his grace and love, wherever he is overcoming sin and helping human beings to grow toward the great communion offered them in Christ." Ibid., 106.

-Ibid., 69. Gutiérrez gives three biblical examples of the absence of God: (1) the empty temple, "God is not there, if those trying to find God do not put into practice the commandment of life and justice"; (2) God is absent in the world of bribery, where those in authority over the people do not respect the law and, therefore, do not establish right and justice causing the death of the innocent; and (3) God is absent in religious activities when those who worship him do not practice justice. He concludes that "when the grace of God's reign is not accepted, when God's demands are not met, the God of the kingdom is absent." Ibid.. 69-75.

"The Irruption of the Poor in Latin America," 122. "El anuncio del reino es un anuncio de Dios. Jesús al anunciarnos $\in l$ reino nos dijo quien era el padre. Ese es el sentido de la proclamación del reino: anunciarnos al Dios del reino." La evangelización y opción por los pobres (Buenos Aires, Argentina: Ediciones Paulinas, 1987), 45. See also The God of Life, 67. A similar view is advanced by Hugo Echegaray (La práctica de Jesús, 3d ed. [Lima: CEP, 1989], 173): "No se puede por eso independizar al Padre de la idea del Reino, ni a este último de Dios." 
Since God cannot be dissociated from His Kingdom, the latter must reveal His character. For this reason, Gutiérrez speaks of the Kingdom of God as incorporating the characteristics of God Himself, such as life, love, truth, peace, justice, and freedom: In particular two aspects, life and justice, are outstanding for our author. As Pernia points out, Gutiérrez predominantly uses the terms "kingdom of life" and "Kingdom of justice" to refer to God's Kingdom.: For instance, in the Gospel according to John, the Peruvian theologian asserts that Jesus is identified as "the king of a Kingdom of life," ${ }^{3}$ whereas in Luke 4:16-21, God's Kingdom is described as a Kingdom of justice.' The

The Truth, 117. Cf. "Theology and spirituality in a Latin American Context," HDB 14 (June-August 1984): 4. For Gutiérrez, God has revealed aspects of $\mathrm{His}$ character both in the Scriptures and in history. Especially, Gutiérrez sees historical events as "the accounts and expression" of God's action (The God of Life, xvi; see also p. 3). Because God's character is revealed through His actions, all human beings can know Him. Consequently, in Gutiérrez's thought God liberates because He is life; God does justice because He is holy; and He enters into a covenant because He is faithful (ibid., 2). Hence liberation and life, and just and holy are all synonymous. For a detailed study of these three aspects of God's character, see ibid., chaps. 1, 2, and 3.

'Pernia, God's Kingdom and Human Liberation, 54.

The Truth, 12. Because Jesus came to proclaim the Kingdom of life, he was persecuted and crucified. Through His resurrection, however, this Kingdom was confirmed by the Father. The acceptance of the kingdom of life, according to Gutiérrez, will help the believers to see "the deeper meaning" of what is called "integral liberation" (ibid.).

The Power of the poor, 14. 
use of these two aspects of God's character, Iife and justice, are significant due to the daily conditions in which most people live in Latin America, a region characterized by premature death and injustice.

As the God of life, God wills life for all human beings. The term "life," Gutiérrez explains, includes not merely breathing but every human dimension as well, such as houses, health, culture, prayer, and evangelization.: In fact, the experience of the Exodus from Egypt reveals to believers a God who loves life.' As a God of justice, on the other hand, He governs history and orientates it toward the establishment of a just society."

Justice and righteousness are the foundations of God's reign," Therefore, God demands that His people practice these two characteristics to build a society of

The Truth, 12; "Church of the Poor," in Born of the Poor, ed. Edward L. Cleary (Notre Dame, IN: University of Notre Dame Press, 1990), 23.

- Egypt is a symbol not only of deprivation and exploitation but also of sin (The God of Life, 3 ).

Ibid. The idea of God as defender of life is based on the liberation of His people from slavery in Egypt. This liberation "expresses the will to life of a God who continually liberates and blesses His people" (ibid., 11; translation altered). By liberating the oppressed, God is revealed as "a liberating God, a living God, and a friend of life" (ibid., 19).

iThe Power of the Poor, 7.

The God of Life, 20. 
equals, for social injustice is incompatible with God's Kingdom.- To love God leads believers to the practice of justice, which Gutiérrez considers an intrinsic element in one's relationship with God. No one who loves God practices injustice. Anyone who in any way contributes to oppression and suffering is an agent of death. Even more specifically, anything contrary to life, whether causing the death of the innocent or oppressing the poor and trampling underfoot their rights, is contrary to God's will.'

Since it is God's will that His Kingdom become a reality, Gutiérrez holds that the petitions of the Lord's prayer, "your kingdom come" and "your will be done on earth as it is in heaven," have basically the same meaning." For this reason, poverty synonymous of death, both physical and cultural death, is rejected because it is contrary to God's

Ibid., 22.

32.

A Theology, 168. See also The Power of the Poor,

The God of Life, 16. The oppression and exploitation of the poor are seen as a choice of death, which is contrary to the God of life (ibid.).

isee The God of Life, 72, 56.

"Ibid., 67. Cf. The Truth, 156; "Theology and Spirituality in a Latin American Context," 4 . Gutiérrez regards any attempt to dissociate God Erom his plan as "the rejection of God's reign, God's will that life, love, and justice reign in history" (The God of Life, 67). 
will.: Appalled by the condition of misery, oppression, and death in which the poor in Latin America live, Gutiérrez agrees with the assertion of Hugo Echegaray that this world, under these conditions, cannot be the place of God's Kingdom, because God is a God of life and justice, not of death.: Therefore, all Latin American Christians and nonChristians who are committed to the poor are called to defend life and struggle for justice." Particularly, Christians are encouraged to keep alive their hope in God's promise to create a new world where life and justice reign." In summation, by using the term "Kingdom of God," Gutiérrez refers to God Himself because it is the expression of both His character and will. This led him to believe that God's presence is real and His Kingdom is realized in history wherever His will is done and justice is practiced. By the same token, the opposite is also true; the absence of

See The Truth, 9-10; A Theology, 291. Poverty means to experience a "premature and unjust death" (The Truth, 158). Any effort for eliminating it "is to bring closer the moment of seeing God face to face, in union with other men" (A Theology, 295-96).

- "Caminando con el pueblo," introduction to La práctica de Jesús, by Hugo Echegaray, 3d ed. (Lima: CEP, 1989), 17. This article was originally published on Pag 4 (1979): 1-11. Sobrino ("Central position of the Reign," 382) also observes that the condition of the poor in Latin America testifies that the present reality is not the kingdom of God.

\footnotetext{
The Truth, 116.

The God of Life, 98.
} 
91

God and the rejection of His Kingdom occurs wherever injustice arises.

\section{The Meaning of the Kingdom of God \\ The expression "Kingdom of God" in Gutiérrez's}

writings has a dual meaning. It refers to both God's sovereignty as well as to the realm where He reigns. The emphasis seems to be on its meaning as a dynamic event to describe principally the activity God exercises as king.: The Kingdom of God means "globalization." As such, nothing escapes God's supremacy.: Agreeing with Norbert Lohfink's statement that the Kingdom points to God's purpose of imposing His sovereign rule on this age and this society, Gutiérrez remarks that the Kingdom of God means that God reigns, that is, among all human beings His love, His fatherhood, and a community of brothers and sisters will reign.

Ibid., 108-109.

- The Power of the Poor, 14. "God's reign is universal, over the cosmos (see Ps 19 and 93) and over history (see Ps 44, 47, 95, 99). God reigns over all nations; the reference here is not to a limited geographic area but to God's sovereignty throughout history" (The God of Life, 108).

N. Lohfink, "Reino de Dios y economía en la Biblia," Communio (March-April 1986): 114, quoted in The God of Life, 197, n. 13.

iThe Power of the Poor, 14. 
Furthermore, the Kingdom of God is understood in a dialectical way. It is seen as both present and future. The Peruvian theologian does not deny that the ultimate realization of the Kingdom is a future event, but he adds that, at the present, it is in the process of being brought to completion.: The Kingdom of God is not something purely interior that happens in the inner part of human beings, but rather something to be realized in history. Here, the concept of just and loving relations among human beings and comunion with God is significant in Gutiérrez's understanding of the Kingdom. For instance, he states that "the Kingdom is realized in a society of brotherhood and justice,"- and that solidarity and love are expressed by participating in the edification of a just society.: He holds that a complete communion of human beings with God and among themselves is not only possible, but that it is also the ultimate goal for humankind. In fact, he maintains that all human beings are destined to this communion, to be realized fully when sin, the obstacle of friendship with God

The God of Life, 100-102. For a treatment in greater detail of this issue see below pp. 113-18.

- A Theology, 232. Temporal progress and the growth of the kingdom "both are directed toward complete communion of men with God and of men among themselves" (ibid., 177). See also The Power of the Poor, 67-68; A Theology, 269. A similar view is shared by Boff and Boff (Salvation and Liberation, 76-83).

See The Truth, 138. 
and others, is conquered by God's grace: To achieve this final goal, all injustice and exploitation must be abolished, and to this end, liberation theology wants to contribute.'

Because the Kingdom is the project of God for human history, Jesus Christ came into this history from the "unimportant and marginal" Galilee to proclaim it. This announcement was heard and accepted by the poor and marginalized, but it was resisted by the powerful and the privileged who repressed those who bore witness to the Kingdom.; Today the kingdom irrupts in history through commitment and solidarity with the poor. It is, therefore, unnoticed by those who hold power in this world."

It was no accident that Jesus emerged from among the poor to proclaim and inaugurate God's Kingdom. In His statement that the time had come and the Kingdom was near (Mark $1: 15$ ) is perceived that a kairos had arrived, not just

See A Theology, 198; 175-78; The Truth, 136-38.

-See A Theology, 263; 15.

The God of Life, 99, 101.

ínid., 100 .

"El Reino es particularmente inesperado para los grandes de este mundo, porque hace su entrada--obligada--a través del compromiso, la toma de partido por el pobre." "Caminando con el pueblo," 17. 
the fulfillment of a date set in advance: This kairos is understood as a propitious time for God's self-manifestation in history. The implications of the coming of this kairos is that God's presence in history is barely noticeable. A spiritual discernment is necessary.' Likewise, it implies that Christians have to be perceptive when God reveals Himself; in other words, they must be vigilant to "the signs of the times." :

The Kingdom of God is also understood as universal. As such, nobody is excluded from it.' Every human being without exception is invited to the Kingdom. Nevertheless, God shows His preference for the poor and oppressed. This predilection for the poor does not diminish God's love for any human being. None is excluded from the Kingdom because of God's preference for the poor. ` Gutiérrez is aware that

The God of Life, 101. In this work, he distinguishes the two Greek words to express time in the New Testament: (1) chronos, which refers to the quantitative, measurable aspects of time, and (2) Kairos, which alludes to a favorable moment rather than to an hour or a date which is measured by the clock or the calendar (see ibid., 100-101).

The Truth, 156 .

The God of Life, 101.

"Vaticano II y la Iglesia latinoamericana," Pag 70 (August 1985): 6 .

This preferential option does not mean that God excludes the rich or the oppressor from the kingdom. It is made clear that all people, regardless of their social condition, are called to the kingdom. What excludes a person--rich or poor, oppressor or oppressed--from the 
it is not easy to keep in balance the tension between the universality of the Kingdom and God's preferential option for the poor.:

Due to their privileged position with respect to the gospel message, the poor become not only the point of departure for liberation theology but also the starting point in understanding the meaning of the Kingdom of God in Gutiérrez's thought.: Commenting on the Gospel according to Matthew, the Peruvian theologian claims that Jesus' teaching starts with the poor (Matthew 5) and ends with the poor (Matthew 25). Therefore, it is from the perspective of the poor that one can comprehend the meaning of the Kingdom promised to them. "The poor and the Kingdom are Iinked realities," and in their relationship God's love is revealed.' Consequently, he suggests that to understand God's kingdom, one must become poor or be committed to them. Because the poor are both the privileged recipients of the

Kingdom is the refusal to be committed to the poor. See The Power of the poor, 126-31.

\section{The God of Life, 116-17.}

-The Kingdom of God "cannot be understood apart from the preference Christ shows for the poor as he reveals to us the Father's universal love" (The Truth, 158).

"The Irruption of the Poor," 121. For Gutiérrez, it is not possible to speak of the kingdom of God without its relationship to the poor ("La Iglesia de los pobres: Perspectiva bíblica," PAndina 30 [April 1980]: 20-21). A similar view is shared by Dussel ("The Kingdom of God and the Poor," 124). 
gospel and its natural messengers, they and those who have ties with their lives and struggles have been granted the grace of receiving and understanding the kingdom.

Gutiérrez is aware of the misunderstandings of what the Kingdom means. For instance, he sees a tendency to superimpose the categories prevalent in the dominant class of society to the Christian experience. Reflecting on the Gospel of John 18:28-19:22, and attempting to correct this misconception, Gutiérrez explains that God's Kingdom is quite different from those found in this world. In the latter, power is exercised to achieve personal glory and obtain a place of honor in society, and above all to dominate, to become absolute sovereigns over others. In the Kingdom of God, on the other hand, power is exercised to serve others, primarily the poor. This service implies action and creativity to build a more just and fraternal society.

The Power of the Poor, 103. Elsewhere it is asserted that "the interpretation that the poor give their life situation opens a rich vein for the understanding of the gift of God's kingdom" (ibid., 101). Gutiérrez believes this to be one of the reasons why God's Kingdom is promised, first of all, to the poor and those who are committed to them. Regarding those who live in wealth and satiety, he thinks their entrance into the kingdom "will be more difficult than 'for a camel to pass through the eye of a needle' (Lk 18:25)." The God of Life, 113.

-The God of Life, 87-88. Gutiérrez reminds his readers of Jesus' principle that the truly great one among His followers would be the one who serves, and that he who would be the first should be the servant of all. See "messianic inversion" (ibid., 88). 
Jesus came not only to reveal the mystery hidden until that moment--God's sovereignty--but also to call His followers to manifest in their lives the characteristics of His Kingdom. Like Jesus, they have the responsibility of pursuing the proclamation of the Kingdom in solidarity and commitment with the poor. The kairos has come and the Kingdom must be announced and established from the perspective of the poor.: Gutiérrez challenges his readers to demonstrate that they are truly disciples of Jesus by announcing the liberation of captives and good news to the poor, as recorded in Luke 4:18-19." He asserts that it is time to oppose injustice, death, and give hope to the oppressed. How one responds to this kairos will determine whether or not one will enter into the kingdom. In short, the term "Kingdom of God," first of all. refers to a dynamic event, and then to a place. It means primarily the reign of God in the life of those who decide

The Power of the Poor, 14.

- "He [Jesus] is proclaiming a kingdom of justice and liberation, to be established in favor of the poor, the oppressed and the marginalized of history" (ibid., 14). The English translation does not reflect the original idea that the Kingdom will be established from the perspective of the poor rather than "in favor of the poor": "Se trata de un reino de justicia y liberación que deberá establecerse y hacerse desde el pobre, el oprimido, el marginado de la historia" (La fuerza histórica de los pobres, 24; emphasis supplied).

See The God of Life, 102-103. 
to be His subjects. Its presence is manifested in a society where God's love reigns and where communion and mutual services exist. This understanding of the Kingdom is the driving force behind Gutiérrez's objectives for society.

\section{The Kingdom of God as Gift and Task}

God freely grants gifts to believers and expects a concrete response from those who accept His gifts. Thus, God's saving love is a gift which demands from those who accept it a commitment to their neighbors. This gratuitousness of God should be the point of departure in the Christian's Iife. If one believes that God loves gratuitously, one should also love freely.: Unless the gratuitous love of God is grasped, it will be impossible to understand the necessity of being committed to those in need. In this sense, the Christian experience is to be lived between the gratuitous gift and the obligation it carries.

Similarly, the Kingdom of God is considered above all as a free gift from God. It is a divine gift. But, if so, do human beings play any role in bringing it about?

See la evangeización y opción por los pobres, 47. God's love marks the lives of human beings, and only by loving can they fuifill themselves as persons. Because their Iives have been marked by gratuitousness, they are "led to love gratuitously and to want to be loved gratuitously" (We Drink from Our Own Wells, trans. Matthew J. O'Conneli [Maryknoll, NY: Orbis Books, 1984], 110).

-The Truth, 36. Cf. The God of Life, 102. 
Gutiérrez responds affirmatively based on his dialectical understanding of the Kingdom. The Kingdom is a divine gift which requires human effort.: The gratuitousness of the gift of the Kingdom calls for an effective action on behalf of the neighbor. By responding to this call, one expresses his or her love for the most needy, a love that meets the tangible needs of the other.:

In Gutiérrez's thought there is no place for passivity or quietism because it implies a denial or distortion of the free love of God: Consequently, those who accept the gift of the kingdom must work for a change in the present social structures; they must reject the abuses of those in power and strive for the establishment of a more

The Truth, 35. For Gutierrez the Kingdom is a free gift and a work in which persons participate through liberating praxis. He states that "the saving action of God does not do away with human responsibility and the human task in history" (ibid.). He further believes that his position is in consonance with the teachings of Augustine and Thomas Aquinas on the matter. While the latter referred to the relationship between the action of God and the action of human beings as the "first cause and second causes, "the former expressed "their connection when he had God say: 'I created you without you, I cannot save you without you'" (ibid.).

-We Drink, 108. Love is perceived as the first and most basic in the Christian's experience. It implies contemplation and practice, that is, worshipping God and putting His will into practice by accepting the gift of His Kingdom. "Reflections from a Latin American Perspective: Finding our Way to Talk about God," in Irruption of the Third World: Challenge to Theology, ed. Virginia Fabella and Sergio Torres (Maryknoll, NY: Orbis, 1981), 225.

The Truth, 35. 
fraternal and just society: Based on the notion that the proclamation of the Kingdom of God is directed to all people, Gutiérrez claims that nobody is excluded from either the gift or its demands. Everyone has the opportunity to make a personal decision--it is made on a daily basis-either for life or death. These are the only two alternatives. By choosing life, one chooses the God of life and enters into a new kind of relation to God and human beings.

Gutiérrez places emphasis on the demand and the praxis because he considers that Christians should actively wait for the ultimate realization of the Kingdom of God. The active participation in building a just society is not separate from Christian theology; it is part of it. Iike Jesus, Christians are called to proclaim God's love and Kingdom in a concrete way. In so doing, they are faithful to His practice. Even more, they are conscienticized about their own situation, while the rupture of the brotherhood as the root of social injustice is revealed to them. The preaching of the gospel has not only a conscienticizing

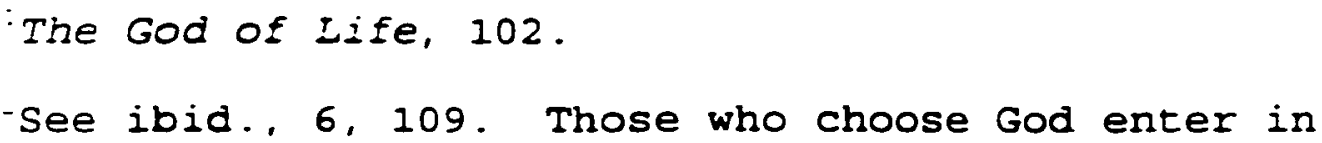
alliance with Him and share in the ethics of His Kingdom. They are called to protect and defend life, while they simultaneously oppose everything which promotes misery and oppression. See ibid., 17.

see "Buscar el Reino," 2. 
function, but it also reminds the Christian community of its aim: that total brotherhood can be achieved, and that every human achievement of brotherhood and justice, though provisional and incomplete, is a step toward total communion.: This fact inspires and encourages the involvement of Christians in history.

Because the gospel announces God's Kingdom as the end of all kinds of oppressions," its message is perceived as subversive. Gutiérrez maintains that the Kingdom will not be fully realized in history while injustice and exploitation continue. Consequently, he claims that in Latin America, the coming of the Kingdom implies the breaking up of the unjust situation of poverty and oppression, and the building of a new and just society where brotherhood is a reality.; He is cautious, however, to make a distinction between the Kingdom of God and the

A Theology, 268-69. By announcing the gospel. Christians become aware that its very center embraces a political dimension (ibid., 112), and that it implies a multiple effort by human beings to obtain justice. This fact should provoke the oppressed to recognize that they are oppressed, and, consequently, it should motivate them to seek Iiberation (see ibid., 270-71).

-Ibid., 272. "The attitude of Christians is based on the understanding that the coming of the Kingdom implies the building of a just society" (ibid., 112).

Ibid., 231. Gutiérrez quotes Wolfhart Pannenberg (see ibid., 248, n. 103).

\footnotetext{
isee ibid., 112, 135 .
} 
establishment of a just society.: While the latter is a provisional and incomplete achievement of human effort in the process of liberation, the former is a divine gift which will bring the final liberation from sin and all its consequences.

The Christian involvement in the transformation of society requires a personal conversion to God. These two aspects--commitment and conversion--are tied together. For Gutiérrez, conversion, understood as the radical transformation of an individual, means behaving like Christ present in the poorest and most helpless.: It is seen as a prerequisite for entering the Kingdom.: Besides, this new attitude avoids any type of modern Pharisaism, which focuses on the fulfiliment of the external formalities of religion while the mind and heart remain untouched.

Conversion is not something that is done once and for all. It is a process in which one continuously grows.

See ibid., 231-32. Gutiérrez warns his readers not only to abstain from equating God's Kingdom with the establishment of a just society, but also to avoid any confusion of the former with revolution (ibid., 135).

- "Liberation Movements and Theology," 142. See also A Theology, 205. Conversion is not perceived as a private attitude, but as "a process which occurs in the socioeconomic, political and cultural medium in which life goes on, and which is to be transformed" ("Liberation, Theology and Proclamation," in The Mystical and Political Dimension of the Christian Faith, ed. Claude Geffré and Gustavo Gutiérrez (New York: Herder and Herder, 1974], 66).

See We Drink, 95-102. 
It implies a development, a long walk marked by stumbling blocks. In this process, like the Exodus from Egypt, the doubts and temptations to return to slavery are quite real.: Moreover, conversion leads individuals to a new relationship with God and among fellow believers.' It no longer means to walk in one's own way, but to walk in the path of the other, especially that of the poor. In so doing, one is brought near to the Kingdom." All this presupposes a break with both a personal and a social dimension of sin," in other

Ibid., 95.

The God of Life, 102. "Conversion always means going out of oneself and openness to the Lord and to others" ("Liberation Movements and Theology," 142). The same idea is repeated in connection with the Kingdom: "La aceptación del Reino de Dios reclama un comportamiento: 'conviértanse', este requerimiento acompaña el don del Reino y genera una nueva actitud ante Dios $Y$ ante el hermano." "El Reino está cerca," Sign 12 (January 1991): 2 .

See The God of Life, 137; A Theology, 199.

The Truth, 5. The notion of $\sin$ has a central place in Gutiérrez's thought. While perceiving in the notion of sin two aspects--personal and social--Gutiérrez (The Truth, 136) emphasizes its social dimension because he considers that this perspective has somehow been neglected within Roman Catholic theology. Even though the Peruvian theologian stresses the social consequences of sin, he does not forget that $\mathrm{sin}$ is always the result of a personal free act. In fact, he believes that society is affected by the free acts of men (ibid., 137). On this issue, he wants to show his agreement with the official teachings of the Roman Catholic church by guoting John Paul II's apostolic exhortation Reconciliatio et paenitentia where this relationship between personal and social sin is treated in detail, especially in section II. He also makes reference to several documents such as Medeliín (peace, 1); John Paul II's homily at the shrine of Zapopan, Mexico just before the Puebla Conference; Puebla (nos. 28, 70, 73, 92, 185, 186, 
words, a break with every obstacle to a real solidarity with the oppressed and the suffering ones.:

Gutiérrez makes clear that for Christians there is no room for neutrality. Either one is in favor of the poor or one is against them. By refraining from serving, one refuses to love and is as culpable as the one who expressly refuses to serve." The choice is clear: either one passively supports the status quo by claiming no responsibility for society, or one decides to be actively present, as a friend of life, without neutrality where the most elementary human rights are violated."

\section{Since the acceptance of the gift of the Kingdom}

brings with it a demand for human action in history, Gutiérrez believes that all those who respond positively and become involved in the building of a better society are children of God.; The fact that they recognize God as

281, 452, 482, 487, 515, 1032, 1258, 1269); and Libertatis Conscientia 54 .

A Theology, 205. Conversion is the starting point for a new life marked by solidarity with the poor. It implies the acknowledgment of the presence of sin at the social and personal levels as the obstacle to full communion with God and solidarity with others, as a hindrance to the creation of a just and human society (we Drink, 96-7).

\section{A Theology, 198.}

The God of Life, 63.

Ibid., 127. Based on Medelín documents (Peace, 14 and 15) Gutiérrez identifies the children of God with the makers of peace. He stresses the fact that "peace is not 
Father, and other human beings as one's brothers and sisters, leads them to strive for establishing a brotherhood and sisterhood here and now.: In so doing, they live the gift of sonship in history.

This adoption as the children of God, as well as the fraternal communion, is celebrated in the Eucharist, which is carried out in community, in ecclesia. The Eucharist is seen as a commemoration of reconciliation and thanksgiving and as a celebration of hope that a new social order will be fully realized in history. 'Thus the Eucharist not only points to the bond which unites God and humans, it also refers to the brotherhood which is being built in history. This sacrament calls people to conversion and commitment in the creation of a just and humane world." Unless one gets

found but it is built," and, therefore, Christians as peaceful people and not simply pacifists "can fight for Iife and justice" (ibid.).

Ibid. It is continually emphasized that Christians as children of God have the obligation of creating "brotherly and sisterly relations among human beings" (The Truth, 36; cf. p. 140). See also A Theology, 272.

"La Eucaristía, sacramento fontal, es una fiesta de reconciliación, acción de gracias y comunión fraterna" (Beber en su propio pozo, 200). (This sentence is missing in the English edition, cf. We Drink, 134).

Gutiérrez suggests that the Eucharist can be considered in two ways. Taken lightly, no problem is perceived, but if it is taken seriously, then the difficulty arises. In the latter case, receiving the Eucharist is "truly an anticipation of and call for a communion" that is not yet possessed within history. The celebration of the Eucharist challenges the present situation of poverty and 
involved in the struggle against exploitation and alienation, the Eucharistic celebration is considered an empty action, an external formality of religion.:

In summary, the Kingdom of God is gift and task. It is not a gift in theory but rather one of work and praxis. It is a gift that requires solidarity with the poor and involvement in the struggle for their liberation. In the Iight of the Kingdom, the process of liberation is perceived as faithfulness to the practice and message of Jesus.

\section{Historical and Eschatological Dimensions of the Kingdom of God}

As previously mentioned, Gutiérrez believes that the Kingdom of God intends to end all type of oppression. However, he continually warns his readers not to confuse the Kingdom with a just society. He denies that a just society is a necessary condition for the Kingdom. They are neither

social inequalities among those who call themselves Christians. Although human history is marked by sin, the Eucharist is celebrated "in the hope of a true communion both within history and beyond it" (The Truth, 45-6). CE. We Drink, 134. See also $A$ Theology, 262-65.

A Theology, 265. Gutiérrez makes clear that communion with God and with other persons implies the abolition of all injustice and exploitation (ibid., 263). He regards those who think they are faithful to the religious demands while at the same time continue exploiting and marginalizing the poor as modern Pharisees. Those who profess to love God but do not take a stand with the poor, the privileged of the Kingdom, are liars (The God of Life, 102). 
closely connected nor do they intersect each other.: If this is so, how can one reconcile this notion with the statement that "the Kingdom of God is realized in a society of brotherhood and justice"?

What is implicit in this tension is the fact that both the external transformation of the social order and the gift of the kingdom are part of the same enterprise. The fulfillment of the Kingdom of God is not only an eschatological reality but also a historical reality manifested in social structures of justice and equality. This perception can be possible only if the tridimensional interpretation of liberation is applied: political Iiberation, liberation throughout history, and Iiberation from sin. Since the notion of liberation embraces these different levels, the question arises: How do unity without confusion and distinction without separation of these three levels influence Gutiérrez's understanding of the kingdom? To answer this question this study now turns to a closer analysis of these levels.

Ibid.

Ibid., 232.

Ibid., 152, 167-68.

isee above pp. 81-83. 
Levels of Liberation

The first level of liberation is grounded in scientific rationality provided by the social sciences. This level reveals the aspirations of the poor to become Eree from socioeconomic and political dependence and aims for the transformation of society as a whole. This historical liberation can be possible only through a social revolution that would allow the emergence of a socialist society.

For this reason, Gutiérrez envisions real liberation tied to social structural changes as well as to personal changes. These two dimensions mutually condition each other.: Nevertheless, he makes it clear that "a social

Ibid., 26-27. Gutiérrez points out that, at the time when he wrote his $A$ Theology of Liberation in 1971, he saw the socialist model as a pattern to follow. Today, after the fall of the Communist bloc, he still thinks that a socialist model is valid for Latin America. Nevertheless, he is open to other possibilities such as Capitalism--a system regarded as "inhuman and anti-Christian" (ibid. 112)--as long as they can eliminate poverty and suffering. Interview by author, January 4, 1994, Lima.

-Gutiérrez rejects any proposition that separates personal change from concrete conditions in order to transform society (The power of the Poor, 28). Although he (A Theology, 35) claims that a transformation of society can help bring about a personal change and vice versa, he does not expect it to happen automatically. To prevent criticism for following a deterministic Marxism, which teaches that structural change brings about personal change, he writes: "There is a mutual dependency, and reciprocal demands, between the human heart and its social milieu, based on a radical unity. It is no more 'mechanistic' to think that a structural change automatically makes for a new humanity, than to think that a 'personal' change guarantees social transformations. Both assumptions are unreal and naive" (The 
transformation, no matter how radical it may be, does not automatically achieve the suppression of all evils.":

A new social order based on respect for others and in which the needs of the poor are taken care of is important but it is not enough.' It is merely the first step, which must be followed by deeper changes. This, in turn, points to the second level: the utopian liberation. This level is grounded in the creative utopian-historical rationality in which human freedom plays a central role and motivates human beings to assume a conscious responsibility of their own destiny. They gradually liberate themselves from all impediments to the unfolding of all dimensions of the new human being and of a different social order. 's Gutiérrez puts it,

the goal is not only better living conditions, a radical change of structures, a social revolution; it is much more: the continuous creation, never

Power of the Poor, 47). See also The Truth, 132-33.

A Theology, 35.

-The Truth, 132.

A Theology, 36-37. Regarding the key role played by human freedom. Gutiérrez agrees with and quotes from the "Instruction on Christian Freedom and Liberation" issued by the Congregation for the Doctrine of the Faith on April 5, 1986. He expresses it in the following manner: "This will to make changes is based on a conviction that social structures do not arise from 'an alleged determinism in history' but 'depend on the responsibility of humankind, who can alter them'." The Truth, 132. Moreover, he observes that Gaudium et Spes (no. 55) advocates the same perspective (ibid., 132-33). 
ending, of a new way to be a man, a permanent cultural revolution.

At this level, the notion of utopia: plays an important role. Three factors, which characterize utopia, are emphasized: "its relationship to historical reality, its verification in praxis, and its rational nature."

Firstly, utopia is to be understood as related to the present historical reality. It is a complex and dynamic relationship given by two interrelated aspects: denunciation and annunciation. Whereas, in its retrospective character, utopia denounces the present unjust social order, in its prospective character it announces a new society, a new order of things which is present in hope but will be a reality in the future. In agreement with paulo Freire, Gutiérrez holds that in order to avoid falling into an

A Theology, 32 (italics in the original). The term "new man" was used by Karl Marx to express that "man will be defined not by what he has but by what he is" (ibid., $38, n$. 12).

-Utopia is, according to Gutiérrez, a human work in which Christians, using their imagination and creativity, can develop, within history, a process of liberation. In so doing, they must start from historical reality with the help of social sciences. This analysis must be illuminated by the word of God accepted in faith. Although the gospel does not provide utopia, it "is no alien to the historical plan" ( $A$ Theology, 238). On the other hand, faith informs the development of utopia, which in turn promotes the liberating praxis among those who are engaged in the building up of a new kind of human being.

$$
\text { Ibid., } 232 .
$$


illusion or evasion of reality, the praxis must necessarily mediate between denunciation and annunciation.:

But utopia is also considered as the "driving force of history and subversive of the existing order." = Utopia is not to be confused with ideology. While the former is seen as a creative force which leads to action, the latter is perceived as masking the reality and contributing to the preservation of the status quo." Consequently, utopia and ideology are perceived as opposing each other. Utopia is a critical and rational element, and, therefore, a dynamic and creative factor in the transformation of society. Social analysis is not enough--to be effective it needs imagination, which is provided by utopia."

The objective of the second level of liberation is the creation of a new person in a qualitatively different

Ibid., 233-34. Cf. Paulo Freire, "Education as Cultural Action: An Introduction," in Conscientization for Liberation, ed. Louis M. Colonnese (Washington, DC: Division for Latin America--USCC, 1971), 119.

-A Theology, 234.

Ibid., 234-35. Based on the assumption that praxis must mediate between denunciation and annunciation, Gutiérrez conceives utopia as a force which leads "to a commitment to support the emergence of a new social consciousness and new relationships among people" (ibid., 234). Insofar as utopia remains connected to social analysis of reality and to praxis, it constitutes "the essence" of the creativity and dynamism of the praxis of liberation; therefore, there is no danger that denunciation can become empty words and annunciation an illusion (ibid).

$$
\text { Ibid., 234-37. }
$$


social order. Gutiérrez distinguishes, however, between the new human being aimed at the utopian liberation and the Pauline term "new person" which resulted from the reconciliation and adoption as children of God. The latter is located in a deeper and decisive third level: liberation from sin.:

The final conquest of sin, which is on the level of faith, is an experience that cannot be achieved either by political or utopian liberation because it transcends the borders of human actions. It is Christ who liberates human beings from sin, from the root of all injustice and oppression. In doing so, Christ opens for humanity the way to full communion with God and with each other. This third level of Iiberation has an eschatological implication because it points to a definitive reality in the future which God Himself will bring. Therefore, all human achievements are considered incomplete and provisional until the eschatological realization of the kingdom of God.:

The Truth, 134-35. Cf. A Theology, 35.

- See $A$ Theclogy, 33-37, 112, 135-36, 238-39. In Gutiérrez's theological system, however, due to the interrelationship of the three levels of liberation, the eschatological hope of the Kingdom of God does not neglect the concrete needs of the present reality. "The hope which overcomes death must be rooted in the heart of the historical praxis." He further observes, "If this hope does not take shape in the present to lead it forward, it will be only an evasion, a futuristic illusion" (ibid., 218). 
All three levels, although distinguished, are united, forming a single process. The relationship between them follows the "Chalcedonian principle": in reference to the Christological dogma: unity without confusion and distinction without separation. For Gutiérrez, utopian liberation (second level) plays a connective role between the historical liberation (first level) and freedom from sin through Christ (third level). This mediation prevents the risk of falling either into a politico-religious messianism or into idealism and evasion.

\section{Partial and Eschatological Realization of the Kingdom}

It should be obvious by now that Gutiérrez's theology underlines the continuity he perceives between temporal matters and the ultimate liberation in Christ. This tridimensional interpretation of liberation allows him to claim that the eschatological Kingdom, the ultimate realization of liberation, is already manifested in the present in all efforts to transform social structures. He believes that Christ's liberation is fulfilled in historical events and liberating political action." This historical liberation not only points out the suppression of poverty

The Truth, 14, see also pp. 121-24.

A Theology, 238.

"Liberation, Praxis, and Christian Faith," 23. 
and oppression, it also makes possible communion among human beings. Thereby, historical liberation is regarded as a sign announcing that a full liberation will be accomplished at the end of time.: Thus, the Kingdom of God is not reserved to the eschaton; it begins in the present world and is revealed in the building of a just society."

This notion of liberation allows Gutiérrez to refute any charge of reducing the Christian doctrine of salvation to political liberation." He strives to balance the

See The God of Life, 104.

A Theology, 72.

Gutiérrez denies the charge of reductionism. For him, it depends on the perspective from which one sees the matter. He writes: "Are we, then, talking about reducing the gospel to purely political terms? Are we advocating a 'political reductionism'? Yes, in the case of those who use it to serve the interests of those in power; no, in the case of those who denounce that usage on the basis of its message of liberation and gratuitous divine love. Yes, in the case of those who place themselves and the gospel in the hands of the mighty of this world; no, in the case of those who identify themselves with the poor Christ and seek to establish solidarity with the dispossessed on this continent. Yes, in the case of those who keep it shackled to an ideology that serves the capitalist system; no, in the case of those who have been set free by the gospel message and then seek to liberate it from the same captivity. Yes, in the case of those who wish to neutralize Christ's liberation by restricting or reducing it to a purely spiritual plan that has nothing to do with the concrete world of human beings; no, in the case of those who believe that Christ's salvation is so total and radical that nothing escapes it. For the latter, evangelization is liberative because it proclaims a total liberation in Christ that includes a transformation of concrete historical and political conditions on the one hand but also conducts that history above and beyond itself to a fulfiliment that is not within the reach of human foresight or any human effort" ("Liberation, Praxis, and Christian Faith," 28-29). See 
historical and eschatological realization of the kingdom. If the autonomy of both the political realm and faith is not respected, it may produce a political-religious movement which will tend to identify the Kingdom of God with revolution. On the other hand, considering these two aspects as belonging to two different planes would mean that they do not affect each other.

How can Christians express their faith in the building of a just social order? Can faith coexist with any political option? Although any identification between historical liberation and the Kingdom is rejected, the former is presented as a precondition for the latter. This does not mean that God's Kingdom is somehow dependent on human efforts, for it is above all a gift. Still, in Gutiérrez's theology there is a tension between the action of God and that of human beings in the process of liberation, between the notion of the Kingdom growing as a result of human action and of the kingdom of God as a gift. He is concerned, on the one hand, with protecting the autonomy and creativity of human beings, and, on the other, with safeguarding God's sovereignty. In his words, the historical, political liberating event is the growth of the Kingdom and is a salvific event; but it is not the coming of the kingdom, not all of salvation. It is the historical realization of the

also The Power of the Poor, 68-69. 
Kingdom and, therefore, it also proclaims its. fuliness. This is where the difference lies.

Gutiérrez finds in this tridimensional understanding of liberation the key to relating the political option with faith. The struggle for a just world is perceived as a struggle for the Kingdom. Human beings participate in the construction of the Kingdom through their involvement in the historical liberation and in the creation of new persons.: To many Gutiérrez seems to equate the struggle for Iiberation with the Kingdom insofar as they pursue the same goal: eliminating sin and fostering communion with God and among fellow believers. At the same time, however, he distinguishes them as far as both have different levels of fulfillment. While the ultimate realization of the kingdom is a future event, at the present the historical liberation reveals only a provisional and incomplete achievement."

\section{A Theology, 177; italics in the original.}

- In agreement with Dom Antonio Fragoso's assertion that the struggle for justice is also the struggle for the Kingdom of God, Gutiérrez (A Theology, 168) claims that "the struggle for a just world in which there is no oppression, servitude, or alienated work will signify the coming of the Kingdom." Juan Luis Segundo, in a similar vein, declares that the view that human beings are constructing the kingdom of God from within history is common and basic for all liberation theologians. Juan Luis Segundo, "CapitalismSocialism: A Theological Crux," in The Mystical and Political Dimension of the Christian Faith, ed. Claude Geffré and Gustavo Gutiérrez (New York: Herder and Herder, 1974), 112.

See A Theology, 153, 168, 177, 198-99, 255. A similar view is advanced by Leonardo Boff ("Salvation in Jesus Christ," 87-91) and by Claude Geffré ("A Prophetic 
A similar tension is perceived in Gutiérrez's treatment of the relationship between the "Promise" and the promises. While the former is understood as the efficacious revelation of God's love and self-communication, the latter are the historical and partial realizations of the Promise. For instance, the old Testament covenant and the kingdom of Israel, according to our author, were historical realizations of the Promise. Nevertheless, the Promise was not exhausted by its partial fulfillments because "it goes beyond them, explains them, and gives them their ultimate meaning. ":

Jesus' proclamation of the Kingdom gives the Promise an eschatological dimension.: This does not mean that the Promise is limited to the end time. For Christ, eschatology is seen as a concern for the present as well. For Gutiérrez, likewise, "the prophetic message proclaims and is realized in a proximate historical event, at the same time, it is projected beyond this event." However, the recognition of the future and present aspects of the

Theology," 14-15).

A Theology, 160-161. The promise "is already fulfilled in historical events, but not yet completely; it incessantly projects itself into the future, creating a permanent historical mobility. The promise is inexhaustible and dominates history, because it is the self-communication of God" (ibid., 161, italics in the original).

Ibid.

Ibid., 163. 
eschatology is not enough. It is also necessary to avoid either the spiritualization of the old Testament message or the spiritual fulfillment in the New Testament of the old Testament promises, as eschatology deals with historical realities such as the grace-sin conflict, the coming of the Kingdom, and the expectation of the parousia.:

In short. Gutiérrez does not deny the otherworldly character of salvation to be brought by the ultimate realization of the Kingdom of God, but rejects the idea that one must quietly wait for it with resignation. He understands the Kingdom of God as already taking place in history, both in the struggle for liberation undertaken by the poor and oppressed and in the process of creating a new human being in a fraternal world where a person is no longer exploited by another. Because he sees Latin America as a society where injustice and exploitation are a way of Iife for the poor, Gutiérrez firmly believes that God's Kingdom necessarily requires the practice of justice in that continent. Thus, for him, the historical realization of the Kingdom has begun, and with it the elimination of all that prevents the oppressed and poor from being fully human. "The Kingdom of God," he concludes, "has come in its fullness into history and embraces the totality of human existence." -

Ibid., 167.

-Ibid. , 299. 
If partial realization of the kingdom has begun in history, what is, then, the role of the church in this historical process of liberation?

\section{The Kingdom and the church}

We noticed that Gutiérrez rejects the idea of equating the church with the kingdom. Instead he regards the church as a sign or sacrament of God's salvation in the world and a provisional manifestation--not its full realization-of the Kingdom.: As a sacramental community, the church is not an end in itself. It exists to serve the Kingdom of God. Outside this reality the church is nothing.: Its purpose is to signify the kingdom of God

See Lineas pastorales, 6; A Theology, 256. While accepting the traditional Roman Catholic definition of the Latin term sacramentum as both the fulfillment and the revelation of God's plan of salvation as well as the efficacious sign of grace, Gutiérrez goes a step further and affirms that through the sacrament, human beings encounter God in history. The church, as visible sacrament of salvation, must become "the efficacious revelation of the call to communion with God and to the unity of all mankind" (ibid., 259). Only by proclaiming this unity with God and of all human beings can the church be understood as the sacrament of salvation. See The Truth, 144-45; $A$ Theology, 278. For a detailed study on Gutiérrez's notion of church as sacrament see, Breckenridge, "The Ecclesiology of Gustavo Gutiérrez Merino," 89-168.

-A Theology, 261. While rejecting ecclesiocentrism, Gutiérrez argues in favor of a different ecclesiological approach, whose point of departure is Christ--"the Poor one" who identifies Himself with the poor and oppressed of this world--calling out to everyone from the midst of the oppressed (The Power of the Poor, 210-11). 
which has already begun in history.: This sacramental function gives the church its provisional character because it is always oriented towards the fulfillment of the reality it signifies. Thus, when he affirms that the church is a sacrament of universal salvation, he is saying that "the church is the sign of the presence of the Kingdom of God." = Agreeing with Congar and the Second Vatican Council, Gutiérrez also describes the church as the "People of God," more exactly as the exodus people of God. The conditions of misery and oppression in Latin America leads him to look back in history to the liberation of the Israelites from Egypt and to find similarities between the two." For him,

A Theology, 261. Elsewhere it is also stated that "the church proclaims a plenitude and a life that will not be fully realized except beyond history, but that already affect the progress of humanity" (The Truth, 145).

The Truth, 158. Because the church is centered in the work of the Holy Spirit, who leads it to attain consciousness of itself as an efficacious sign of salvation, the church is called to transform the life of human beings (ibid., 144).

Gutiérrez takes into consideration the renewed prominence given by Vatican II to the expression "People of God" See The Truth, 146, 197, n. 135; A Theology, 261; The God of Life, 104.

The Latin American poor are experiencing similar conditions of "oppression," "repression, " "alienated work, " and "humiliations" to those described in the initial chapters of the book of Exodus (A Theology, 156). Gutiérrez writes: The Exodus "remains vital and contemporary due to similar historical experiences which the People of God undergo" (ibid.. I59). R. MCAfee Brown (Theology in the New Key, 88-90), in a similar vein, states that the experience of the Israelites can be repeated in their modern 
the Exodus experience is "paradigmatic" of Latin Americans struggling for liberation, and should be understood today in the same way the Israelites understood theirs.:

As pointed out by Christian Duquoc, one finds two paradigms in Gutiérrez's theology: the Exodus and the Cross.: The Passover was the passage of the Israelites from bondage to freedom, from Egyptian oppression to the promised land. Similarly, Jesus' work was also a passage: from sin, oppression, and death to grace, freedom, and life." For this reason, Gutiérrez sees in Jesus' program--expressed at the beginning of His ministry in Luke 4:16-20--a similarity with the role played by the Exodus in the old Testament.'

The contemporary poor and oppressed are regarded as the new people of God, created by Christ's liberation ${ }^{\prime}$ and,

counterparts today. For a well-documented discussion of the use of the Exodus by liberation theologians, see Atilio $R$. Dupertuis, Liberation Theology: A Study in Its Soteriology (Berrien Springs, MI: Andrews University Press, 1982), chap. 2 .

A Theology, 159.

The Truth, 20.

The God of Life, 14. The resurrection is considered as a Passover or passage for Christians. It announces that "life, not death, has the final word in history" (ibid., 15).

$$
\text { Ibid., 6-7. }
$$

'A Theology, 158. Like the Israelites of old, the poor, the new people of God, must work to overthrow the unjust structures which keep them in bondage. Liberation requires the participation of the oppressed. This is expressed in the following terms: "The future of history 
like the Israelites of old, entering into covenant with God.: Thus the Latin American church is perceived as the people of God marching toward "a new heaven and a new earth." : Through suffering and oppression the Exodus of the contemporary people of God has begun ${ }^{3}$ a journey toward the full realization of the Kingdom."

Hence, like the old Testament prophets, the Latin American church is called to feed hope to God's people

belongs to the poor and exploited. True liberation will be the work of the oppressed themselves; in them, the Lord saves history" (ibid., 208).

The poor and oppressed enter into covenant with God, not as individual persons, but as a community (The God of Life, 34). Like the people of God in the old Testament, those who sign a covenant with God must be "defenders of Iife in history" (ibid., 17), because one of the great demands of this covenant is the establishment of justice and righteousness (ibid., 55). Thus to be faithful to the covenant implies not only to remember the origin and demands of the covenant but also "to move ahead, to travel by unknown ways" (ibid., 35).

- A Theology, 50. See also "Caminando con el pueblo," 12. Convinced that the church is a "pilgrim in history," Gutiérrez believes that all those who have been incorporated into the Christian community through baptism have "a historical journey to make" before the parousia becomes a reality (The God of Life, 86). Similarly, Jürgen Moltmann (Church in the Power of the Spirit [New York:

Harper \& Row, 1977], 83-84) perceives the church as leading a modern Exodus "out of captivity, poverty, and inhumanity into the freedom, the glory, and the righteousness of God's new man."

"Two Theological Perspectives," 250. The oppressed are encouraged to live the Exodus rather than to preach it (ibid., 251).

The God of Life, 86. 
during difficult times. This is done by announcing a hope that is rooted in the concrete history of the oppressed people, a hope inspired by the ultimate fulfillment of the Kingdom. If the church separates itself from the Kingdom, it has no raison d'etre, and will lose its critical attitude to all human realizations of the Kingdom. This ability to be critical prevents the ultimate Kingdom from being absorbed into history.:

While in its historical pilgrimage, the church, as the community of Jesus' disciples, must denounce all obstacles to fellowship and justice. This denunciation implies more than mere criticism of the present inhuman order. It also implies self-criticism, for the church is part of this order. It must announce both the gospel and the incompatibility of the Kingdom with the unjust and oppressive social order, so that the oppressed become aware of their condition and motivated to seek their own liberation.- At the same time, the task of the church is

Ibid., 207. Although the church is never identified with the Kingdom, it is related to and "must bear witness to the kingdom by forming and organizing itself as a community" (ibid.). See also "Buscar el Reino," 51.

-See A Theology, 267-69. The proclamation of the gospel "calls and assembles a Church bound up with the popular classes of the continent," Gutiérrez writes, "a church making common cause with them in order to abolish a society built by and for a few; joining forces with them in the building of a different social order, which will be more just and human for all." "The Praxis of Liberation and the Christian Faith," Lumvit 29 (1974): 399. Cf. The Power of the Poor, 70 . 
not limited to the poor--the victims of oppression--but embraces all society, including those responsible for the situation of poverty and those who benefit from it.:

Gutiérrez makes it clear that the oppressors too need to be liberated from their own power, from their ambition, from their selfishness, and from their inhuman condition as oppressors. :

Just as the promised land meant the end of the Israelites' pilgrimage and a radical change of status, the Kingdom of God presents a reality full of happiness and joy for the people of God, for oppression and misery will be eliminated. The ultimate realization of the kingdom will be a place where they will no longer consider themselves aliens, but owners of a land where they can have their daily food and enjoy freedom and dignity.' While waiting for that

See A Theology, 265-79. For Gutiérrez, the mission of the church is to evangelize and conscienticize all people in society. Although these two processes take place simultaneously, he believes that the conscientization of the poor will stimulate both the development of their political and Christian awareness so that they can take the reins of their own destiny (The power of the poor, 98). Convinced that the poor have a place of privilege in the Kingdom, Gutiérrez (The Truth, 158) insists that they must also have a place of privilege in the historical task of the church; otherwise, it can no longer be the sign of the presence of the Kingdom of God.

$$
\begin{aligned}
& \text { A Theology, 275-76. } \\
& \text { Ibid., 167-68. } \\
& \text { 'The God of Iife, } 17 .
\end{aligned}
$$


special event, the church is called to show a correlation between its teachings and its actions by manifesting solidarity, friendship, and unity among its members as a sign of the Kingdom.

\section{Summary and conclusion}

In this chapter, Gutiérrez's view on the Kingdom of God has been considered in the light of his monistic conception of history and of his notion of liberation as a multidimensional process in which God and human beings are seen as agents of change. The tridimensional interpretation of liberation plays a key role in Gutiérrez's understanding of the Kingdom for several reasons: First, it allows him to keep in balance the tension between the historical realization of the Kingdom and its full implementation. Next, it allows him to describe the kingdom as a gift and task. Finally, it permits him to deny any charge of reducing salvation to political liberation or suggesting that human beings are their own liberators.

It is clear for Gutiérrez that God's Kingdom means God's sovereignty manifested in fraternal relationship, communion, and reconciliation among human beings. As such it cannot be indifferent to socioeconomic and political conditions. It is perceived as a future reality becoming present in the historical liberation achieved by human beings. By applying his understanding of the Kingdom to the present Latin American condition, Gutiérrez seeks a 
historical transformation of the conditions of life here and now.

To avoid the accusation that he is working to establish the Kingdom of God here on earth, Gutiérrez describes the Kingdom as a dialectical reality. On the one hand, it is partially realized in a society of brotherhood and justice by human effort. On the other hand, it is fully realized in the ultimate liberation from $\sin$; it is a divine gift that transcends history. In other words, while the liberation from sin is God's work, historical and utopian liberation are considered the ground of human activity. The gratuitousness of the Kingdom does not exclude human cooperation; on the contrary, the acceptance of the gift demands an active response. Without human action there is no historical realization of the kingdom.

within this context, far from equating the church with the kingdom, Gutiérrez sees the church as the people of God on march to their promised land, the Kingdom of God. The church is a sacrament of the Kingdom. As such it is called to struggle to signify in history a partial, but at the same time genuine, anticipation of the ultimate kingdom. Iike in Moses' time, the God of the Exodus is the same God who is working today to liberate the poor and oppressed. 
But God's action must be complemented with human action, otherwise the Iiberation is not authentic and complete.: Although in his later writings, such as the God of Life (1989), he has attempted to balance his political emphasis with a doctrinal exposition based on biblical grounds, Gutiérrez's emphasis on praxis seems to present the danger of reducing the gospel into sociopolitical ideology and the church as a religious-political party. In other words, his emphasis on the historical praxis of liberation runs the risk of dissolving transcendence into immanence. It is precisely this danger which has caused strong reaction from an important sector of the Roman Catholic Church, which criticizes Gutiérrez's theology for being both influenced by Marxist ideology and in conflict with the official teachings of the church. To what extent are these criticisms valid? To these and other related issues this study turns its attention in chapter 4 .

:A Theology, 91. A genuine theology of liberation is possible only when the poor and oppressed become the artisans of their own liberation ("Hope of Liberation," 37). 
CHAPTER IV

\title{
THE KINGDOM OF GOD IN THE DOCUMENTS OF THE SECOND VATICAN COUNCIL
}

\begin{abstract}
As mentioned in chapter 2, from the time of Augustine up to the mid-twentieth century the traditional Roman Catholic view of the kingdom of God tended to identify its presence on earth with the Roman Catholic Church. The church was thus considered to be basically holy, without spot, and in no need of reform or change. The second Vatican Council, a turning point for Roman Catholicism, brought a change to this triumphalistic attitude. As noted by Peter Henrici, professor of history and modern philosophy at the Pontifical Gregorian University of Rome, Vatican II was a singular event in the history of councils. It was convoked neither to answer an ecclesial emergency nor to Eace doctrinal misunderstandings or heresies. It was not convened to pronounce any condemnations or to formulate infallible dogmas.: Its

'Peter Henrici, "The Council's Development to Maturity: An Experience of Pre-Conciliar Theology," Communio $17(1990)$ : 504-5. Cf. Giuseppe Alberigo, "1965-1995: Thirty Years After Vatican II," in History of Vatican II, ed. Giuseppe Alberigo and Joseph A. Komonchak (Maryknoll, NY: Orbis, 1995), 1:xii. In his opening speech, John XXIII
\end{abstract}


principal task was to bring the Roman Catholic Church up to date. According to the programmatic opening speech of Pope John XXIII, the council had three main purposes: the opening of the church to the modern world, the promotion of Christian unity through ecumenical dialogue, and the closer identification of the church with the poor."

In view of the pastoral purpose of Vatican II, one cannot expect to find any elaborate treatment of the concept of the Kingdom of God in its final documents. However, the concept is present in most of them. The purpose of this chapter is to examine it in the documents produced by the Second Vatican Council.

\section{The Pre-conciliar Debate}

Since the conciliar debate had its roots in the preconciliar period, the latter merits some attention before examining the conciliar documents.

In the years prior to Vatican II, great tensions existed inside Roman Catholicism between the prevalent

\footnotetext{
stated that for discussing a doctrine a council was not necessary. In dealing with errors, he suggested that the church should opt for "mercy" rather than for "severity." Instead of condemning error, the church should demonstrate the validity of its teaching. John XXIII, "Pope John's Opening Speech to the Council," in The Documents of Vatican II, ed. Walter Abbott (New York: America Press, 1966), 71516 .
}

See John XXIII's Opening Speech at Vatican II (Abbott, 710-19). 
traditional orthodoxy and a more progressive tendency.: Roman Catholicism was affected by the eruption of liberalism, a consequence of the Enlightenment, in Europe. This trend was prominently humanist and, as such, it emphasized human progress by suggesting that people are able to solve their own problems and build a better world by themselves. This European liberalism inspired a trend which Pope Pius X (1903-14) labeled "modernism." Although this movement was condemned by the official teaching of the Roman Catholic Church at the beginning of the present century, : its influence was felt in the new theology flowering prior to the Second Vatican Council.' The latter was represented by such outstanding scholars as Hans Urs von Balthasar (1905-88), Jean Danielou (1905-74), Yves Congar (1904-95), Karl Rahner (1904-84), Henry de Lubac (1896-1991), Marie

A helpeul overview of the historical and theological Eramework in which Vatican II took place may be found in Carl F. Wisloff, "Recent Trends in Roman Catholicism," Thm 10 (April 1985): 10-15.

- See for example, the Decree of Holy Office Lamentabili (July 3, I907), and the papal encyclical of pope Pius X: Pascendi dominici gregis (September 8, 1907), no. 39. See also Timorhy G. McCarthy, The Catholic Tradition: Before and After Vacican II 1878-1993 (Chicago: Loyola University Press, 1994), 49-53.

See Thomas P. Rausch, Catholicism at the Dawn of the Third Millenzium (Collegeville, MN: Liturgical Press, 1996), 4; Christopher Hollis, The Achievements of Vatican II (New York: Hawthorn Books, 1967), 27; Richard Cowden-Guido, John Paul II and the Battle for Vatican II (Manassas, VA: Trinity Communications, 1986), 15-17. 
Dominique Chenu (1895-1990), and Pierre Teilhard de Chardin $(1881-1955)$.

Most of these progressive theologians were either disciplined, silenced, or forbidden to write on certain topics.: For example, Teilhard de Chardin, a Jesuit priest and noted paleontologist, strove to relate Christian faith to the contemporary scientific understanding of nature. He envisioned history as moving along a divine milieu towards its final realization in Christ. Believing that creation is a continuing process and that every person must work to

These progressive scholars, whose approach was biblical and historical, turned to patristic, liturgical, and sacramental sources of the Roman Catholic tradition in order to reassess the present in light of the past. They opposed the dualism that characterized neo-scholastic theology: profane and sacred, church and world, temporal and eternal, nature and grace. The "new theology," a term used to describe their work, was seen as a new kind of modernism. Consequently, they were attacked by the representatives of the traditional Roman Catholic orthodoxy, followers of neoscholastic theology. In his encyclical Humani generis (1950), Pope Pius XII linked the new theology to modernism and rejected it. He also called Roman Catholic scholars to return to Thomistic orthodoxy in both philosophy and theology. McCarthy, The Catholic Tradition, 55-58. See also Rausch, Catholicism, 7-8; Aidan Nichols, The Shape of Catholic Theology (Edinburgh: T. \& T. Clark, 1991), 337-43.

Carlo Falconi. The Popes in the Twentieth Century, trans. Muriel Grindrod (Boston: Little, Brown and Co., 1967), 283. For a discussion of the movement known as "the new theology" and its representatives both in Germany and France, see T. Mark Schoof, A survey of Catholic Theology 1800-1970, trans. N. D. Smith (New York: Paulist Newman Press, 1970), 93-156, 194-227; Klaus wittstadt, "On the Eve of the Second Vatican Council (July 1--October 10, 1962)," in History of Vatican II, ed. Giuseppe Alberigo and Joseph A. Komonchak (Maryknoll, NY: Orbis, 1995), 1:451-62. 
complete it, Teilhard regarded human activity as closely related to the bringing forth of the kingdom of God.: His writings were considered too controversial by his superiors, and were denied publication. ${ }^{2}$

Another theologian who came in conflict with the Roman hierarchy was Marie Dominique Chenu, a Dominican historian of medieval theology. He was committed not only to solid historical research but also to justice and the resolution of the social problems facing the church in the contemporary world. Convinced that the church and its theologians should not remain disengaged from contemporary events, he called Christians to actively participate in the social movements of their time, a call that has found echo in liberation theologians committed to the transformation of society as a partial realization of the kingdom. Chenu was

Teilhard de Chardin, The Divine Milieu, trans.

Bernard Wall (New York: Harper \& Brothers, 1960), 25-40. As an example of the link between temporal activity and the Kingdom of God, Teilhard de Chardin wrote: "Try, with God's help, to perceive the connection--even physical and natural - which binds your labour with the building of the kingdom of Heaven; try to realize that heaven itself smiles upon you and, through your works, draws you to itself" (ibid.. 35). see also ibid., 135.

- The Oxford Dictionary of Christian Church (1983), s.v. "Teilhard de Chardin, Pierre." After Teilhard's death in 1955, most of his writings were printed and translated into several languages, just a few years before the opening of the Second Vatican Council.

Marie-Dominique Chenu, Pour une théologie du travail (Paris: Editions du Seuil, 1955). Cf. idem, Faith and Theology, trans. Denis Hickey (New York: Macmilian, 1968), 137 EE. 
censured after the publication of his academic manifesto entitled A School of Theology: Le Saulchoir in 1937. Being at that time the director at Le Saulchoir, Chenu was removed from his post. He was also forbidden to teach and his book was placed in the Index in 1942, probably because of its "apparently modernistic recognition of historicity and human experience within theology." "

Similarly, Yves Congar, a prominent Roman Catholic ecclesiologist of this century, also faced theological difficulties with the Roman hierarchy. It began when in his attempt to contribute to the renewal of the church and Christian unity, Congar wrote on ministry, laity, and ecumenism.' He, like Chenu, insisted that Christians should

'walter Principe, "Chenu, M.-D," The HarperCollins Encyclopedia of Catiolicism (1995), 304. Cf. McCarthy, The Catholic Tradition, 57. In this work, Chenu suggested that a text is understood only in its historical, cultural, social, and political context. He regarded the whole scope of human history and the life of the church itself as a place for theology (ibid.).

-Schoof, A Survey of Catholic Theology, 104. See also Thomas O'Meara, "'Raid on the Dominicans': The Repression of 1954," Am 170 (February 5, 1994): 8-11. According to Allessandro Maggiolini, among other things Chenu was charged with having followed Mohler and the modernists, "in belictling the value of reason and privileging religious feeling (sensus religious) and experience (experientia)." Allesandro Maggiolini, "The Magisterial Teaching on Experience in the Twentieth Century: From the Modernist Crisis to the Second Vatican Council," Communio $23(1996)$ : 237.

Thomas O'Meara, "Congar, Yves," The HarperColiins Encyclopedia of Catholicism (1995), 351-52. Cf. idem, "The 
participate in the transformation of the world. Convinced

that the ultimate realization of the Kingdom of God is a divine gift, Congar contended that this does not rule out the participation of human beings in the process of building up the Kingdom.: His writings became suspected of

Raid on the Dominicans, " 11. Congar pioneered Roman Catholic thinking on the role of the laity in the church and showed that the priesthood of all believers, as believed by protestants, is a concept supported by both scripture and church fathers. In the preface of his Dialogue between Christians, Congar described his journey in dealing with ecumenism between 1929 and 1963. There he admitted that when he realized that ecumenism presupposed a movement of conversion and reform coextensive with the whole life of all communions, he wanted to begin at home among his own people. In so doing, Congar chose to provide the doctrinal basis for a reform of the Roman Catholic Church. He described his ecumenical task as an attempt "to rotate the Catholic Church through a few degrees on its own axis in the direction of convergence towards others and a possible unanimity with them." Yves Congar, Dialogue between Christians, trans. Philip Loretz (Westminster, MD: Newman Press, 1966), 21. See also pp. 28-44. The publication of Congar's Divided Christendom: A Catholic study of the Problem of Reunion, trans. M. A. Bousfield (London: Centenary Press, 1939) displeased some members of the Roman curia who strongly reacted against him. Congar recalled this experience as follows: "From the beginning of 1947 to the end of 1956 I knew nothing from that quarter [Rome] but an uninterrupted series of denunciations, warnings, restrictive or discriminatory measures and mistrustful interventions." Congar, Dialogue between Christians, 34.

Congar, Lay People in the Church, 89. He illustrated the approach to the kingdom as gift and task with the following metaphor: "It is as if a master should get his pupil to make a sketch and should then take it over himself, transfiguring it with matchless skill but not

failing to work into his picture what the unskilled hand had tried to draw. God indeed will give all from on high, and all will be new, but he purposes that we should have nothing in which we have not been enabled to cooperate" (ibid., 104). This perspective was adopted later by Vatican II. The council made it clear that to build the earthly city and 
containing dangerous innovations. As a result, he was forbidden both to teach at Le Saulchoir and to publish a second edition of his writings.: He not only had to stop publishing but also had to submit his writings to prior censorship.:

Henri de Lubac, like Chenu and Congar, was also silenced. He came under suspicion after the publication of his Surnaturel in 1946. In this work, de Lubac strongly criticized the neo-scholastic theologies of the supernatural, which separated Christianity from secular concerns." In turn, he was criticized for compromising the gratuity of the supernatural order.' Consequently, he was also forbidden to teach and his writings were removed from libraries.

to seek the Kingdom of God are not opposed to one another. Human efforts have a role in the manifestation of the Kingdom, but it is God, while supporting and transfiguring these human efforts, who will realize the final manifestation of His Kingdom. See pp. 143-51 below.

Aidan Nichols, From Newman to Congar (Edinburgh: T. \& T. Clark, 1990), 252. Cf. Rausch, Catholicism, 8.

-O'Meara, "Raid on the Dominicans," 11.

Vincent Miller, "de Lubac, Henry," The HarperCollins Encyclopedia of Catholicism (1995), 797.

'Susan wood, "The Nature-Grace Problematic Within Henri de Lubac's Christological Paradox," Communio 19 (1992): 394. Cf. Nichols, From Newman to Congar, 206.

'David L. Schlinder, "Cardinal Henri de Lubac," Communio 18 (1991): 296. 
Interestingly enough most of the progressive theologians who were disciplined and/or silenced during the period of Pius XII (1939-58) were later rehabilitated, and influenced the renewal of Roman Catholicism at Vatican II. Some of them played a role in the preparatory work of the council, and in the council itself. ${ }^{3}$ others, who were

See Wittstadt, "On the Eve of the Second Vatican Council," I:456-62. Cf. O'Meara, "The Raid on the Dominicans," 13 .

-James I. McCue, "A Roman Catholic Perspective," Dial 5 (1966): 180. Even Teilhard de Chardin through his writings influenced the council. His name was mentioned during the public discussions. As Mccarthy correctly observes the Pastoral Constitution on the Church in the Modern World uses some of de Chardin's phrases when it speaks of the impact of science and technology on human development (art. 5 [Abbott, 203]), of Christ as "the goal of all human history" (art. 10 [Abbott, 208]), and when it notes that "the human race has passed from a rather static concept of reality to a more dynamic, evolutionary one" (art. 5 [Abbott, 204]). McCarthy, The Catholic Tradition, 57-58. CE. Abbott, 204, n. 11. Similarly Gutiérrez (A Theology, 76, n. 35) perceives de Chardin's influence, even though it has not been openly acknowledged, in the conclusions of the first part of Gaudium et spes. See, for instance, arts. 22, 32, 39, 45 (Abbott, 220-22, 230-31, 237, $247-48$ ).

Congar and de Lubac were named as theological advisors to the pre-conciliar theological commission in preparation for Vatican II. Congar not only worked on the major conciliar documents, but he also helped to write the "Message to the World" announced at the opening of the council, whereas de Lubac's contribution is manifested in the making of the Dogmatic Constitution on Divine Revelation. See Nichols, From Newman to Congar, 206, 212, 252-53. Cf. Schoof, A Survey of Catholic Theology, 236. There is an useful summary of de Iubac's influence on the council in Karl H. Neufeld, "In the Service of the Council: Bishops and Theologians at the Second Vatican council," in Vatican II: Assessment and Perspective, ed. Rene Latourelle (Mahwah, NJ: Paulist press, 1988), 1:88-99. On Congar's 
prevented by the hierarchy from participating in the most important preparatory commissions, were nominated as experts at the beginning of the council.: Still others, even though they were not appointed as official experts, helped to shape a number of conciliar documents.?

influence see Nichols, From Newman to Congar, 252-62. Jean Daniélou was also an expert at the council. He was consulted on the pastoral Constitution on the Church in the Modern World. The HarperCollins Encyclopedia of Catholicism (1995), S.v. "Daniélou, Jean."

Karl Rahner, who came in conflict with the Roman hierarchy during the 1950s, was unpopular because he had spoken both of a church of sinners and of a sinful church. This perspective was in contradiction to the triumphalistic view of the teaching authority in Roman Catholicism. Likewise, Rahner's support for eucharistic concelebration was criticized by Pius XII and he was forbidden to write on this subject. As a result, he was prevented by the Roman hierarchy from joining any of the more important preparatory commissions for the council. However, on 22 March 1961, he was appointed as an adviser for the Preparatory Commission on the Administration of the Sacraments. In October 1962 his name was among the list of theologians nominated by John XXIII as official council experts. Herbert Vorgrimler. "Karl Rahner: The Theologian's Contribution," in Vatican II Revisited, ed. Alberic stacpoole (Minneapolis, MN: Winston Press, 1986), 37-42. Cf. Wittstadt, "On the Eve of the Second Vatican Council," 1:455-56; McCue, "A Roman Catholic Perspective," 180-81. A brief account of the theological difficulties between Rahner and the Roman Catholic hierarchy and Rahner's contribution to Vatican II is found in Vorgrimler, "Karl Rahner," 32-46.

-Schoof, A Survey, 236. For example, Chenu, who did not achieve the statis of expert, was available as advisor to several French bishops. Wittstadt, "On the Eve of the Second Vatican Council," 1:461-62. Congar acknowledges that at the council "so much of what blossomed and bore fruit" there was due to the seed Chenu had sown. Yves Congar, "Marie-Dominique Chenu," in Vorgrimler and Vander Gucht, Bilanz der Theologie II, 101, quoted in Wittstadt, "On the Eve of the Second Vatican Council," 1:461. 
According to Peter Henrici, the theological work developed prior to Vatican II was the basis for the work of the bishops. He concludes that the council did not produce a new theology; it only brought to light that which already existed, that is, the council "reviewed, adjusted and corrected" the pre-conciliar theology so that it could be approved in the conciliar texts." If Henrici's conclusion is correct, both the theological work and the tension between conservative and progressive Roman Catholic theologians found their way into the conciliar debate. It is precisely that unresolved tension that seems to be present in Vatican II's documents as well as in postconciliar Roman Catholic theology.

The Dogmatic Constitution on the Church, for example, describes the church by means of several images. Among them, the image of the people of God, according to René Latourelle, attempted to turn the hierarchical notion of the church upside down "by asserting the equality of all Christians by reason of their baptism." : However, this image of the church was overshadowed and almost disappeared in the post-conciliar debate. Latourelle notes that

'Henrici, "The Council's Development," 505.

According to McCue ("A Roman Catholic Perspective," 180) the most important effect of Vatican II was the adoption of what had been the theology of the Roman Catholic "left" during the quarter century preceding the council.

-René Latourelle, "Vatican II," Dictionary of Fundamental Theology (1994), 1158. 
preference is given to the image of the church as a mystery of communion, probably because it "seems to provide a greater bulwark against a democratic conception of the church.": Thus, when the representatives of the traditional and progressive streams disagree on an issue, they are both able to find in Vatican II's documents support for their theological views. The question still remains: How has this tension affected the council's notion of the Kingdom of God? The following section is an analysis of this idea in the conciliar documents.

\section{Vatican II and the Kingdom of God}

It is well-known that the second Vatican Council was more concerned with the renewal of the church than with the discussion or establishment of any new doctrine.: Consequently, a conciliar definition of the kingdom of God was not expected. This does not mean, however, that this notion is absent in Vatican II's documents. Stephen Benko notes that most of the conciliar documents are so "deeply permeated" with the idea of God's Kingdom that one may say that the tone of the whole council was attuned to this notion.

Ibid., 1160 .

-See Abbott, 98, 97, n. 2.

Benko, "The Kingdom of God," 571. Benko concludes that the notion of the Kingdom is so important that four major documents--Lumen gentium, Dei verbum, Sacrosanctum 
The bishops at Vatican II were well aware of the difficulties posed by the tension between conservative and progressive Roman Catholic theologians. This seems to be one of the reasons why the bishops opted for a generic and ambivalent language to deal with the notion of the Kingdom of God and its relation to the church. This approach helped them to achieve a broad consensus on the issue.

The council used different phrases to refer to the Kingdom of God. Most of them denote an otherworldly reality. For instance, it is called the "Kingdom of heaven,": "the fatherland above," " "heavenly city," " "the lasting city," ${ }^{i}$ and "new earth." Nevertheless, the council also designated it with the phrase "Kingdom of Christ," ${ }^{i}$ a concilium, and Gaudium et spes--are based upon it (ibid., 572 ).

"Dogmatic Constitution on the Church," art. 3 (Abbott, 16).

-Second Vatican Council, "Decree on Ecumenism," art. 2 (Abbott, 344).

"Pastoral Constitution on the Church in the Modern world," art. 57 (Abbott, 262).

"Dogmatic Constitution on the Church," art. 44 (Abbott, 75).

"Pastoral Constitution on the Church in the Modern World," art. 39 (Abbott, 237).

"Dogmatic Constitution on the Church," arts. 5, 13, 35, 36 (Abbott, 18, 31, 62). Cf. "Pastoral Constitution on the Church in the Modern World," art. 39 (Abbott, 237); "Decree on the Apostolate of the Laity," art. 2 (Abbott, 491). 
term with an ambivalent connotation. It is used to refer to both the Kingdom of God on earth, the church, and to the Kingdom in heaven.

Being consistent with the transcendent emphasis, the Kingdom is described variously as a reality "beyond the calculations and bonds of flesh and blood," $=$ in which creation itself will be restored and will enjoy the freedom of the glory of the sons of God." It is considered "the consummation of the earth and of humanity." As such it is the goal of the people of God, " "a new dwelling place and a new earth where justice will abide, and whose blessedness will answer and surpass all the longings for peace which spring up in the human heart." In short, the term "Kingdom of God," as used in the conciliar document, has a dual meaning. It refers to both God's sovereignty as well as to the domain where He reigns.

See "Dogmatic Constitution on the Church," arts. 3 , 5, 44 (Abbott, 16-18, 75).

Ibid., art. 58 (Abbott, 89).

'Ibid., art. 36 (Abbott, 62).

$\therefore$ "Pastoral Constitution on the Church in the Modern World," art. 39 (Abbott, 237).

"Ibid., art. 1 (Abbott, 200). See also "Dogmatic Constitution on the Church," art. 9 (Abbott, 26); "Decree on Ecumenism," arts. 2, 3 (Abbott, 344, 346).

"Pastoral Constitution on the Church in the Modern World," art. 39 (Abbott, 237).

"Dogmatic Constitution on the Church," arts. 5, 9 (Abbott, 17-18, 25-26). Article 6 of the Constitution on 
Furthermore, the Kingdom is understood in a dialectical way. It is perceived as bott. present and future: As a historical and present reality, the kingdom, which Christ will hand over to His Father in its finished form at the end of time, $=$ is already manifested on earth in mystery and in its initial stage. The Dogmatic Constitution on the Church clearly stated that the central message of Christ was the coming of the kingdom. Its arrival was revealed in His teachings, miracles, and most of all in His person: Moreover, it is said that Jesus Christ established His Kingdom on earth, that is, the church.' As a future and otherworldly reality, the kingdom is described as an eternal and universal "new age" characterized by truth, life,

the Sacred Liturgy asserts that by His death and resurrection, Christ has set us free from the power of Satan and "brought us into the kingdom of His Father" (Abbott, 140).

"Dogmatic Constitution on the Church," arts. 5, 35 (Abbott, 17-18, 61-62); cf. "Pastoral Constitution on the Church in the Modern World," art. 39 (Abbott, 237-38).

- Pastoral Constitution on the Church in the Modern World," art. 39 (Abbott, 237-38). See also "Dogmatic Constitution on the Church," art. 36 (Abbott, 62); "Decree on the Ministry and life of Priests," art. 2 (Abbott, 536).

"Dogmatic Constitution on the Church," art. 5 (Abbott, 17-18). See also the "Decree on the Missionary Activity of the Church," art. 12 (Abbott, 598).

$\therefore$ "Dogmatic Constitution on the Church," art. 3 (Abbott, 16). In the "Dogmatic Constitution of Divine Revelation" (arts. 15, 17 [Abbott, 122-23]), the council fathers also affirm that the principal purpose of the old Testament was to prepare humankind for the coming both of Christ and of the Kingdom, but in the New Testament Christ established His Kingdom on earth. 
holiness, grace, justice, love and peace." Thus the council adopted a view of the Kingdom that keeps in tension the fact that it is at the same time a present possession of the people of God and a Euture goal to be reached at the end of time.:

If the kingdom has been already inaugurated and will be given fully at the end by God, to what extent is human effort necessary to bring it about? According to the council, the fact that the Kingdom is a divine gift does not rule out the participation of human beings in building it up. Thus, while stating that it is the church's mission to proclaim and to establish the Kingdom among all people until the time when it will fully display itself in heaven, the council made it clear that this mission has been entrusted not only to the hierarchy, ' but also to the laity. 'Hence,

"Pastoral Constitution on the Church in the Modern World," art. 39 (Abbott, 237). Cf. "Dogmatic Constitution on the Church," art. 36 (Abbott, 62).

(Abbott, 25-26).

'Ibid., art. 5 (Abbott, 17-18). This conciliar document presents the church as established and made manifest by the outpouring of the Holy Spirit. It is expected that this church will find its glorious fulfillment at the end of time when all the just will be gathered in the universal church by God (ibid., art. 2 [Abbott, 15-16]). see also "Declaration on the Relationship of the Church to Non-Christian Religions," art. I (Abbott, 660-61).

"Decree on the Ministry and life of Priests," arts. I. 15, 42 (Abbott, 584, 603, 629).

"Dogmatic Constitution on the Church," arts. 35,36 (Abbott, 61-63). This document also states that the laity 
due to its involvement in temporal affairs of every sort, the conciliar documents assigned to the laity a special function in the world. Its responsibility is to sanctify the world "from within, in the manner of leaven," by living according to the divinely revealed truth and with all the means of grace granted by God to the Roman Catholic Church. If the laity fails to do so, the growth of God's Kingdom is retarded:

Vatican II encouraged Christians to fulfill their earthly responsibilities, since they cannot be separated from their religious lives. It is expected that the hope of Christians for a new earth will motivate their participation in making the world a better place where human beings can really enjoy life.' These two aspects are so closely

"seek the Kingdom of God by engaging in temporal affairs and by ordering them according to the plan of God" (ibid., art. 3i).

Ibid., art. 31 (Abbott, 58). This function of sanctifying the world from within is described in the same document (art. 34 [Abbott, 60]) as a consecration of the world. Avery Dulles (The Dimensions of the Church

[Westminster, MD: Newman Press, 1967], 81-82) points out that the term consecration in this definition is used in a wide sense. It means not only a withdrawal of something from the world to be devoted exclusively to God, but also it indicates a transformation of the world into the kingdom of God.

"Decree on Ecumenism," art. 4 (Abbott, 348).

"Pastoral Constitution on the Church in the Modern world," art. 39 (Abbott, 237). Indeed the council encourages the laity to participate politically in the creation of a new world (ibid., arts 63-77 [Abbott, 27189]). 
related that the eternal salvation of Christians may be jeopardized if they neglect their earthly duties.: Since their task is to spread the kingdom of God, and to seek the justice characteristic of this Kingdom, " Christians should wait for the ultimate realization of God's Kingdom not in idleness but with diligence, working for the betterment of this world." Thus, the council kept in balanced tension the notion that the Kingdom is God's work that demands an active cooperation by human beings.

Since Christians are called to dedicate themselves to earthly service in order to prepare the material of the

Ibid., art. 43 (Abbott, 243). By tying temporal involvement and human activity to salvation, the council manifested the importance the church gives to these issues, demonstrating that it is not indifferent to this world. -"Decree on the Apostolate of the Laity," arts. 3,
4,7 (Abbott, 492, 494, 498).

"Pastoral Constitution on the Church in the Modern World," art. 21 (Abbott, 219-20). Here one finds echoes of the teachings of Chenu and Congar. Chenu gave theological importance to human work, especially to the involvement of Christians in social movements. He called Christians, especially theologians, to be open to the world and its problems and to participate in the social movements instead of wasting time in scholastic discussions. See M. D. Chenu, Faith and Theology, $137 \mathrm{ff.} \mathrm{Cf.} \mathrm{idem,} \mathrm{Pour} \mathrm{une} \mathrm{théologie} \mathrm{du}$ travail; idem, Is Theology a science? trans. A. H. N. GreenArmytage (London: Burns \& Oates, 1959). In a similar way, Congar (Lay People, 89) insisted that it is every

Christian's responsibility to participate in the transformation of the world and the building up of the church. In other words, in the temporal realm, the laity should seek to create a more just and humane society where the people may be able to respond freely to the call of God. Cf. Yves Congar, Christians Active in the World, trans. F. Hepburne-Scott (New York: Herder and Herder, 1968), 78-80. 
celestial realm, it is necessary to discuss the relationship between earthly progress and the growth of the Kingdom. Are these two concepts closely related or completely separated?

The answer provided by the council is ambivalent. While acknowledging a close relation between the two, it insisted on distinguishing them as two different realities:

Earthly progress must be carefully distinguished from the growth of Christ's Kingdom. Nevertheless, to the extent that the former can contribute to the better ordering of human society, it is of vital concern to the kingdom of God.

Progressive Roman Catholic theologians regard this conciliar text as a vague statement because it neither completely separates nor sufficiently identifies these two realities." In other words, its interpretation will depend on the kind "Pastoral Constitution on the Church in the Modern world," art. 38 (Abbott, 236).

"Pastoral Constitution on the Church in the Modern World," art. 39 (Abbott, 237).

In his analysis of article 39 of the Pastoral Constitution on the Church in the Modern World, Gutiérrez (A Theology, 168-72) shows the present confrontation of various theological trends within Roman Catholicism. For instance, he (ibid., 186, n. 86) remarks about the opposition of thirty-seven bishops to the final version of this article. They considered that an adequate distinction between temporal progress and the growth of the Kingdom was impossible, because charity unites the two processes. Even more, they regarded the statement that the first was of importance to the second as a vague formula which says nothing. Regarding the argument of these bishops, Schillebeeckx believes that it was well founded. See "Foi chrétienne et attente terrestre," L'Eglise dans le monde de ce temps (Tours: Mame, 1967), 135, n. 5, quoted in Gutiérrez, A Theology, 186, n. 86. 
of lens one uses to read it.: On the one hand, conservative Roman Catholics using a dualist approach ${ }^{2}$ will emphasize the distinction. It implies that the goals of human progress and of the Kingdom are different. While the growth of the Kingdom is regarded as the church's work, earthly progress is important for the church insofar as it serves the institutional progress of the church. This dualist perspective suggests a discontinuity between Kingdom and history.

On the other hand, from their monist perspective,

Gutiérrez (A Theology, 169) notes that the terms used in the article 39 of Gaudium et spes "are intentionally general, making different interpretations possible." A useful study on the interpretation of article 39 of the pastoral Constitution on the Church in the Modern World may be found in Pantelis, "Reino de Dios e Iglesia," 135-59; Juan Luis Segundo, "Evangelización $y$ humanización," PersD 41 (March 1970): 9-17.

The distinction of planes approach, so predominant in Roman Catholic movements of Europe, particularly in France around 1950, had a significant impact within Roman Catholicism by distinguishing between the church and the world as two dimensions in the one plan of God. By and large, this perspective was incorporated in the documents of Vatican II. For instance, it was said that the church has a mission to fulfill both in the spiritual and the temporal orders, and that these realms are connected in God's plan of a new creation. Second Vatican Council, "Decree on the Apostolate of the Laity," art. 5 (Abbott, 495-96). See Gutiérrez, A Theology, 56; idem, "Two Theological Perspectives," 245.

The monist approach regards the so-called profane history of the world and salvation history as unified. There is only one history. Clarifications of this affirmation are found in Karl Rahner, Theological Investigations, trans. Karl-H. Kruger (Baltimore: Helicon Press, 1966), 5:97-114. Cf. Gutiérrez, A Theology, 153-68. 
progressive Roman Catholics stress earthly progress as being "of vital concern to the Kingdom." They perceive that human progress and the growth of the Kingdom are tied together, implying that the new heavens and the new earth will be fashioned out of those realities which we now know." In other words, the goals of human progress and of the Kingdom are the same.- Both seek human Iiberation and progress in building a better society where God's love reigns and is manifested in the fraternal communion of human beings.

Whether earthly progress and the growtin of the Kingdom are identified or distinguished, whether they have the same goal or not, Vatican II made it clear that the

The implication is based on the following statement: "The expectation of a new earth must not weaken but rather stimulate our concern for cultivating this one. For here grows the body of a new human family, a body which even now is able to give some kind of foreshadowing of the new age." "Pastoral Constitution on the Church in the Modern World," art. 39 (Abbott, 237-38). The same notion is repeated in dealing with the liturgy: "In the earthly liturgy, by way of foretaste, we share in that heavenly liturgy which is celebrated in the holy city of Jerusalem toward which we journey as pilgrims." Second Vatican Council, "Constitution on the Sacred Liturgy," art. 8 (Abbott, 141). Dulies (The Dimensions of the Church, 77) correctly observes that even though later documents of Vatican II show a greater concern with the temporal order, they do not cancel out the teachings in the constitution on the Liturgy.

-Gutiérrez emphasizes present life in this world. He insists that salvation happens not only in the other worldly life, in the ultimate kingdom, but also in this Iife. Therefore, the transformation of this world and the creation of an authentic brotherhood among men are considered as growth of the Kingdom of God. See pp. 113-16 above. 
establishment of the Kingdom will not be the result of human effort but of God's gracious intervention.' However, human beings are invited to participate in the building of a more humane world because the existence of a just society is regarded as an anticipation of the ultimate Kingdom.:

Thus, one of the major accomplishments of Vatican II has been to encourage the church to enter into dialogue with the world. Particularly, the laity were called on to cooperate in the regulation of the affairs of economic and social Iife, to struggle to improve the way of life of the poor and the suffering, and to secure peace in the world.' Even so, this did not mean that the mission of the church was in the political, economic, or social order. It remained in the religious sphere: The church, however, did reserve the right to intervene on issues that did not correspond to its area of action. The church did not want

:Decree on the Missionary Activity of the Church," art. 42 (Abbott, 630).

-In the "Message to Humanity" (Abbott, 6-7), the council declared that it is God's plan to be involved in the world, so that "through love God's Kingdom may already shine out on earth in some fashion as a preview of God's eternal Kingdom." Here one finds traces of the fine hand of Congar who insisted that as a messianic people, the church has a mission for the world: to help it grow toward the kingdom of God. Congar, Lay People, 89, 104; cf. idem, Un peuple messianique (Paris: Éditions du Cerf, 1975), 173. See above p. 134, n. 1 .

Ibid., art. 12 (Abbott, 598-99).

"Pastoral Constitution on the Church in the Modern World," 42 (Abbott, 241). 
to be aloof from the temporal reality, because out of its religious mission comes "a function, a light, and an energy which can serve to structure and consolidate the human community according to the divine law.":

In synthesis, to achieve a broad consensus on the issue, Vatican II's documents used the phrase "Kingdom of God" to express a dual meaning. It means both God's sovereignty as well as the realm where He exercises His authority. It refers to the transcendent Kingdom of heaven as well as to the church. It also alludes to a present and yet future reality.: As such, the kingdom is already present in a restricted way but it will reach its full reality in the future. It seems that traditional Roman Catholics have tended to emphasize the transcendent and future characteristics of the Kingdom, whereas the progressive ones stressed its historical and present aspects.

Vatican II strove to adopt a balanced position between the supernatural approach, which emphasizes God's initiative in the final realization of the Kingdom, and the natural perspective, which perceives the historical realization of the kingdom to be brought about by human effort. As Schillebeeckx notes, in the Pastoral

Ibia.

-It is noteworthy to see that the council shares the Protestant view of the Kingdom as present and future reality. See pp. 41-43 above. 
Constitution on the Church there is a warning about two dangers: first, the danger of not taking seriously the building of a better future on earth, and, second, the danger of identifying a self-made future with the Kingdom of God.: How to keep a balanced view about the relationship between human expectation of the future here on earth and the eschatological Kingdom is, according to Elizabeth Lord, the crucial issue for post-conciliar theology:

The Kingdom and the Church

The Second Vatican Council brought in a significant shift in ecclesiological perspective by distinguishing between the church and the Kingdom of God. Today the Roman Catholic Church seems to understand itself not as the kingdom but as the community which has received the mission "to proclaim and to establish among all peoples the kingdom of Christ and of God.":

At Vatican II the church regarded itself as "an exile": which is "journeying in a foreign land" away from

'Edward Schillebeeckx, The Mission of the Church, trans. N. D. Smith (New York: Seabury Press, 1973), 84.

-Elizabeth Lord, "Human History and the Kingdom of God: Past Perspectives and Those of J. L. Segundo, "HeyJ 30 (1989): 297 . (Abbott, 18).

"Dogmatic Constitution on the Church," art. 5

Ibid., art. 6 (Abbott, 19-20). "The Church... will attain her full perfection only in the glory of heaven. Then will come the time of the restoration of all things 
its Lord, and whose goal is the Kingdom that God will establish.: The church saw itself as a pilgrim whose mission is to serve the Kingdom, not to take its place." Furthermore, it is significant to observe that the bishops did not use the metaphor of the Kingdom to explain the nature of the church. ${ }^{3}$

(Acts $3: 21$ ). . . . However, until there is a new heaven and a new earth where justice dwells (cf. 2 Pet. 3:13), the pilgrim Church in her sacraments and institutions, which pertain to this present time, takes on the appearance of this passing world" (ibid., art. 48 [Abbott, 78-79]).

Ibid., art. 9 (Abbott, 26). A similar idea is found in the "Pastoral Constitution on the Church in the Modern World," art. 45 (Abbott, 247): "While helping the world and receiving many benefits from it, the church has a single intention: that God's kingdom may come, and that the salvation of the whole human race may come to pass." See also "Dogmatic Constitution on the Church," arts. 7, 14 (Abbott, 21, 32) ; "Decree on Ecumenism," art. 6 (Abbott, 350).

-See pp. 35-37 above.

See Second Vatican Council, "Dogmatic Constitution on the Church," arts. 6, 7 (Abbott, 18-22). Lumen Gentium went through several stages of conception and revisions. In fact, the bishops deliberated on three modified schemas of this conciliar document. In the first two drafts, no mention is found regarding the concept of the Kingdom of God. The fifth section of the first version of the second draft, for instance, describes the church as the Kingdom. A change is noticed in the sixth section of the second version of the same draft: the image of the church as the "kingdom" is replaced by the "house and family of God." In the final draft, however, a new section (art. 5) on the kingdom was inserted in the document. Herwi Rikhof, The Concept of Church (London: Sheed and Ward, 1981), 11-66. See also Gérard Philips, "Dogmatic Constitution on the Church: History of the Constitution," in Commentary on the Documents of Vatican II, ed. Herbert Vorgrimler, 5 vols. (New York: Herder and Herder, 1967-69), 1:105-137. 
Still, for the council, the distinction between the church and the Kingdom did not mean that they were disconnected. The bishops saw the relationship between the two as essentially dialectical, non-identical yet nondissociated. For them this relationship was as close as was Christ's relationship to the Kingdom. As Christ made the Kingdom visible through His presence, His person, His works, and His words, in the same way the church makes the Kingdom visible because it is "the kingdom of Christ now present in mystery.": Moreover, as Christ proclaimed the arrival of the Kingdom, and through His miracles inaugurated it, so the church has received the same mission." The bishops perceived both Christ and the church as instruments for the proclamation and the establishing of God's Kingdom.

While the council made a distinction between the two, it came close to identifying the church and the kingdom when it declared that the church "becomes on earth the initial budding forth of that kingdom." ${ }^{3}$ Furthermore, the

Second Vatican Council, "Dogmatic Constitution on the Church," art. 3 (Abbott, 16).

Ibid., art. 5 (Abbott, 18).

Ibid. In his message at the end of the synod of Bishops in October 29, 1967, Pope Paul VI, alluding to Vatican II, refers to the church as the "budding forth" of the kingdom. Then he asserts that this Kingdom, "although not fully realized now on earth, will one day become the perfect Kingdom of God." Paul VI, speech reproduced by Francis X. Murphy and Gary MacEoin, Synod 167: A New Sound in Rome (Milwaukee, WI: Bruce Publishing Co., 1968), 224. Cf. Eugene R. Fairweather, "The Church," in The Second 
church is described as "the Kingdom of Christ now present in mystery" and growing "visibly in the world through the power of God.": This implies that both the kingdom and the church are present and growing phenomena. As Kevin McNamara remarks, "sustained by God's power the Kingdom grows, and with it the church which is its visible expression." : Thus, a careful reading suggests that the council refrained from making a sharp differentiation between the church and the Kingdom. Nor are the sovereignty and the basic meaning of God's Kingdom expressed clearly enough in Lumen Gentium.' "The church always takes precedence over the kingdom of God," Kristen E. Skydsgaard remarks, and this prevents the

Vatican Council: Studies by Eight Anglican Observers, ed. Bernard Pawley (London: Oxford University Press, 1967), 645 .

Second Vatican Council, "Dogmatic Constitution on the Church," art. 3 (Abbott, 16). John C. Haughey suggests that the closest the Vatican II documents come to identifying Kingdom and Church is the statement found in art. 3 of the constitution on the Church. "Church and Kingdom: Ecclesiology in the Light of Eschatology," IS 29 (1968): 84. Likewise, the Lutheran theologian Kristen $E$. Skydsgaard insists that by declaring that the church is not the Kingdom of God in all its perfection but the beginning of it, Lumen Gentium "still cradles the idea of her unbroken continuity." "The Church as Mystery and as People of God," in Dialogue on the Way, ed. George L. Lindbeck (Minneapolis: Augsburg, 1965), 169.

Kevin McNamara, "The Mystery of the Church," in Vatican II: The Constitution on the Church; A Theological and Pastoral Commentary, ed. Kevin McNamara (Chicago, IL: Franciscan Herald Press, 1968), 82.

See Second Vatican Council, "Dogmatic Constitution on the Church," arts. 3, 5 (Abbott, 16-18). 
document "Erom arriving at a clear distinction.": Likewise, Christopher Butler, Abbot of Downside, England, believes that Vatican II took a "middle line" on the issue of identification or non-identification between the church and the ringdom.-

It appears that following the practice of previous councils, vatican II attempted to achieve and express a broad consensus among Roman Catholic bishops and to leave open unsettled issues. The nature of the church is one of those undetermined questions. The different perspectives on the church affect the perception of how the church is related to God's Kingdom. Thus, according to Avery Dulles, some of the questions left open by the council are simply "whether the Kingdom is present on earth beyond the borders of the church," and "whether the final Kingdom will be

:Skydsgaard, "The Church as Mystery and as People of God," 168-69. Skydsgaard suggests that the Roman Catholic Church mistakenly has interpreted the Kingdom of God on the basis of the self-understanding of the church. As a result, the addition of the section on the kingdom adds nothing to the ecclesiology contained in Lumen Gentium, because "the whole concept of the kingdom of God is incorporated harmoniously into a preconceived idea of the church" (ibid., $172-73$ ).

-Christopher Butler, The Theology of Vatican II

(London: Darton, Longman \& Todd, 1967), 65. Commenting on article 5 of the Dogmatic Constitution of the Church, Butler says: "Scripture scholars will observe that there is a blurring of ideas here" (ibid.). 
anything other than the church itself in its final glorious condition." :

One may discern among current Roman Catholic theologians a tension between two general tendencies--the traditional or conservative side and a progressive one. The former is inclined to refer to statements where Vatican II reaffirmed the positions of Trent and Vatican I as the hermeneutical key for understanding all other passages. The second group, by contrast, tends to interpret the latest council as the end of the post-Tridentine era and the beginning of a new one.: Given these divergent viewpoints, it is often difficult for Roman Catholic theologians and

\footnotetext{
'Dulles, "The Catholic Ecclesiology since Vatican II," 4. In the document entitled "The One Church of Jesus Christ: Selected Themes in Ecclesiology on the Occasion of the 20th Anniversary of the End of the Second Vatican Council," the International Theological Commission affirms the identity of the future heavenly church with the future fullness of the Kingdom of God. It states: "It is evident that, in the teaching of the Council, there can be no difference, as to the reality to come about at the end of time, between the perfected Church (consummata) and the perfected kingdom (consummatum)." Regarding the earthIy church, it also declares: "To belong to the kingdom cannot fail to constitute a belonging--at least implicit--to the Church." L'unique Église du Christ, ed. Pierre Eyt (Paris: Editions du Centurion, 1985), 68, 70, quoted in Dulles, "The Catholic Ecclesiology," 13, n. 4.

The conservative view states that the Kingdom is wherever the church exists; to be in the church is to be in the Kingdom. On the other hand, the liberal perspective affirms that the church is wherever the Kingdom exists. See McBrien, Church: The Continuing Quest, 37-41.
} 
exegetes to reach a consensus regarding the identity or lack of identity of the church and the Kingdom.'

In summation, by taking an ambivalent position Vatican II distinguishes, and at the same time identifies, church and kingdom. On the one hand, the transcendent and eschatological dimensions of the Kingdom are contrasted with the church, a community in journey toward the kingdom. On the other hand, the council talks about the church as the earthly manifestation of the Kingdom. In Vatican II, especially in the Dogmatic Constitution on the Church, the Kingdom's present aspect on earth is so closely related to the church that the document seems to maintain the traditional theory, which equates church and Kingdom.

\section{The Kingdom of God and the Church's social Doctrine}

After the Second Vatican Council, the social doctrine of the Roman Catholic Church contained in papal, conciliar, and episcopal pronouncements had a new

See Richard P. MCBrien, The Church in the Thought of the Bishop John Robinson (Philadelphia: Westminster, 1966), 51-52. According to Dulles ("The Catholic Ecclesiology," 5), ecclesiologists who prefer to think of the church as the Body of Christ or the sacrament of christ hold that "the Church alone is the embodiment on earth of the kingdom of God." But for those committed to the "Servant" model, the church is "one of many agencies intended to make the world a place for freedom, peace, justice, and prosperity." All these values "are seen as embodiments of the Kingdom." Dulles suggests that a tension between these two viewpoints on the church-Kingdom relationship permeates much of the post-conciliar literature on ecclesiology within Roman Catholicism. 
beginning.: Because of its concern for the poor and its demand for justice and equity, the contemporary social doctrine has been usually associated with the formation and development of liberation theology in Latin America. As could be expected, it contained the tension between conservative and progressive trends already present during the conciliar debate. This section is limited to a general synthesis of relevant aspects of post-conciliar social doctrine in connection with the theme of the kingdom.

Vatican II led the church not only to open itself to the questions of the world, but also to look for new ways by which the church may influence society. Several Roman Catholic theologians recognized Vatican II's major contribution to social doctrine as largely contained within two of its major documents: the Dogmatic Constitution of the Church and the Pastoral Constitution on the Church in the

\footnotetext{
'Pope Leo XIII's Rerum novarum (1891) and Pius XI's Quadragesimo anno (1931) laid down the principles of Roman Catholic social doctrine on the problems resulting from industrialism, but pope John XXIII in his encyclical Mater et magistra (1961) brought a new spirit into the social doctrine documents. As David O'Brien and Thomas Shannon note, Leo XIII's and Pius XI's encyclicals reflect a triumphalist ecclesiology and antidemocratic values, whereas the modern documents, starting with John XXIII, reveal a vision of the church as servant to humanity, and an increasing emphasis on popular participation. David $\mathrm{J}$. O'Brien and Thomas Shannon, Catholic Social Thought: The Documentary Heritage (Maryknoll, NY: Orbis, 1992), 1. See Hollis, The Achievements of Vatican II, 90-91.
} 
Modern World.: The latter especially is an attempt to synthesize the assertions on social issues made from Pope Leo XIII (1878-1903) to Paul VI (1963-78). In this document, the council made it clear that it is the social doctrine of the church that is to guide political and socioeconomic changes.

In dealing with the social issue, the pastoral Constitution on the Church in the Modern World (Gaudium et spes) followed a developmental approach already used by John XXIII in his encyclicals Mater et magistra (1961) and Pacem

\footnotetext{
Marcos McGrath, Archbishop of Panama, considers the Dogmatic Constitution of the Church (Lumen Gentium) as the foundation of the council, and the Pastoral Constitution on the Church in the Modern world (Gaudium et Spes) as its application. The former concentrated its attention in a renewed theology of the church, while the latter offered a method for the application of Lumen Gentium to the key problems of the church in the world today. Marcos McGrath, "The Impact of Gaudium et Spes: Medellin, Puebla, and Pastoral Creativity," in The Church and Culture since Vatican II, ed. Joseph Gremillion (Notre Dame, IN: University of Notre Dame Press, 1985), 62-64; cf. Michael Stogre, "Commentary on the Pastoral Constitution on the Church in the Modern World," in The Church Renewed, ed. George P. Schner (Lanham, MD: University Press of America, 1986), 20. Likewise, Gutiérrez and most Latin American liberation theologians see Vatican II's major contribution as contained in these two Constitutions. See Juan Luis Segundo, Grace and the Human Condition, trans. John Drury (Maryknoll, NY: Orbis, 1973), 133; Gutiérrez, A Theology, $58,151$.
}

See "Pastoral Constitution on the Church in the Modern World," art. 63 (Abbott, 271-72). 
in terris (1963):: These two documents emphasized the need

for economic development to make possible the elimination of existing injustices. Because Gaudium et spes spoke of development as the solution to the problems of the poor countries, : it was regarded by Gustavo Gutiérrez as an irenic description of the human situation. As such, this conciliar document not only avoided the more conflictual aspects but also stayed away from the sharper confrontations among social classes and countries. ${ }^{3}$ In spite of this weakness, the Peruvian theologian perceived some aspects of the idea of liberation in Gaudium et spes which were expressed in a timid way."

While approving a reform of the world's socioeconomic structure, Vatican II appealed to the rich nations to make the necessary changes both for altruistic and moral reasons. The council warned that unless injustice is eradicated the international community is under the threat of war. See "Pastoral Constitution on the Church in the Modern World," arts. 69, 85, 83 (Abbott, 278-79, 297-99).

-Gutiérrez, A Theology, 33-34; cf. "Pastoral Constitution on the Church in the Modern world, " arts. 65$71,85-88$ (Abbott, 273-81, 299-303).

Gutiérrez, A Theology, 34. Dennis McCann observes that liberation theology is strongly opposed to the developmental approach but is open to Marxism. See McCann, Christian Realism and Liberation Theology (Maryknoll, NY: Orbis, 1981), 146-48, 158-60.

iThe Pastoral Constitution on the Church in the Modern World (art. 55 [Abbott, 261]) makes reference to the birth of a new humanism, "one in which man is defined first of all by his responsibility toward his brothers and toward history." Furthermore, it asserts that humankind longs for a "fuIl and free Iife" worthy of human beings (ibid., art. 9 [Abbott, 207]). Cf. Gutiérrez, A Theology, 33-34. 
Pope Paul VI's encyclical Populorum progressio (1967) went a step Eurther.: While a dualist approach that separates the spiritual and the temporal order was kept, it denounced the international imperialism of money, existing injustices, and the growing gap between rich and poor countries.: Paul VI called for the creation of a new society in which all persons could live truly human lives and "where liberty is not an idle word, where the needy Lazarus can sit down with the rich man at the same banquet table.": Nevertheless, rather than addressing the poor and oppressed, the encyclical addressed the rich nations. Instead of encouraging the poor to struggle to change their

- For a discussion on the importance of Populorum progressio see Gutiérrez, A Theology, 33-35.

- "Founded to build the Kingdom of Heaven on earth rather than to acquire temporal power, the Church openly avows that the two powers--Church and state--are distinct from one another; that each is supreme in its own sphere of competency." Paul VI, Populorum progressio, $\S 13$ in The Papal Encyciicals, comp. Claudia Carlen (Wilmington, NC: McGrath Pub. Co.. 1990), 5:185.

See Paul VI, Populorum progressio, \$ 24-34 (Carlen, 5:187-89). Paul VI insisted that the present situation of injustice should be challenged and overcome ( $\$ 26)$. Even though he calls for radical changes in the structure of society, he believes that this should not be done by violent revolution, but by planned reforms ( $\$ 30-31,33-34)$.

Because he rejected liberal capitalism and addressed the issues of land reform (\$ 24), the Wall Street Journal denounced the encyclical as "warmed-over Marxism." Editorial, Wall street Journal, March 30, 1967, 14.

92).

'Paul VI, Populorum progressio, \$47 (Carlen, 5:191- 
present situation and take control of their own destiny. Paul VI asked the rich countries to carry out the necessary changes. For this reason, Gutiérrez regards Populorum progressio as "a transitional document.": Despite his criticism to the approach of this encyclical, the Peruvian theologian acknowledges that his tridimensional notion of "total liberation" is inspired by Populorum progressio ( $\$$ 21) where a reference to "integral development" is made." As a response to the call made by Paul VI in his Populorum progressio, the bishops of the Third World both in their message of $1967^{\circ}$ and in the documents of the Medellin Conference in $1968^{\circ}$ presented the theme of liberation from a new perspective. Liberation was no longer seen from the point of view of the great countries but from those in the periphery.

:Gutiérrez, A Theology, 34.

-See Gutiérrez, "Vaticano II y la Iglesia latinoamericana," 8, n. 27; idem, "A Path of Reflection, an Intent to Speak of God," in Liberation Thinking: An Evangelical Assessment, ed. W. Dayton Roberts (Monrovia, CA: MARC Publications, 1987), 41-42.

See Comisión Episcopal de Acción Social, Between Honesty and Hope, trans. John Drury (Maryknoll, NY: Maryknoll Publications, 1970), 9-11.

"Especially see the documents on "justice" and "peace" in The Church in the Present-Day: Conclusions, 4065.

Gutiérrez, A Theology, 35. 
Medeliin lifted up the concept of liberation. While Gaudium et spes and Populorum progressio had used the word "development" as the solution for poor countries, Medelin changed the emphasis and spoke of "liberation" in the Latin American context.: Right at the outset, the bishops at Medellín emphasized a holistic concept of salvation by declaring that God wants to liberate all people from sin and all its effects such as hunger, misery, oppression, and ignorance.

"The expression "integral vocation" is used in Gaudium et spes, arts. 10, 11, 57, 59, 61, 63, 64, 75, 91, and Ad gentes, art. 8; "integral development" is alluded to in Populorum progressio $\$ 14-16$, while "integral human development and liberation" is used in Medelín's conclusions (Justice, 4).

Medeliin, Justice, 3. Gutiérrez (A Theology, 13435) believes that the work of Vatican II has been complemented by post-conciliar synods, episcopal conferences, and papal encyclicals. Especially the Medelin Conference is regarded as the turning point in the social doctrine of the church. For instance, he observes that while Vatican II addresses the problem of underdevelopment from the standpoint of the rich nations, Medelinn faces it from the perspective of the poor countries. The relationship between the church and the world, in vatican II, is described in a way which tends to neutralize the conflicts, whereas Medelin describes the Latin American world as being in full revolution and calls the church to be committed to the poor. While Vatican II outlines a general plan for church renewal, Medeliin provides directions for the church to be transformed to ministry in a world of poverty. Edward Schillebeeckx points out, in a similar way, that Medelín's final conclusions opposed the developmental approach supported by Vatican II as the basis for liberation. Instead the bishops proclaimed the message of God's Kingdom and Jesus' preference for the persons relegated to the boundaries of society. Schillebeeckx, "Liberation Theology between Medelín and Puebla," 3. 
Likewise, Medeliín endorsed Vatican II's position of not confusing temporal progress and God's Kingdom. However, Medelin saw that these two aspects are tied together and called for avoidance of any "dualism which separates temporal tasks from the work of sanctification.": It seems that by accepting the unity of salvation history and world history, Medelin stressed the interpretation that regards temporal progress and the Kingdom as having the same goals.: Consequently. Medelín spoke of development and human Iiberation as a foretaste of the Kingdom." on this earth one can have a foretaste of what will be the definitive Kingdom. As Cardinal Juan Landázuri Ricketts declared in his inaugural address at the Medelin Conference, the realization of the Kingdom of God in Latin America requires

:Medellin, Justice, 5. The document on Catechesis makes a similar argument: "While avoiding confusion or simplistic identification, it [the gospel] must always make clear the profound unity that exists between God's plan of salvation realized in Christ, and the aspirations of man; between the history of salvation and human history; between the Church, the people of God, and the temporal communities; between the revelation by God and the experience of man; between the supernatural gifts and charismas and human values" (Medelín, Catechesis, 4).

- In their "Message to the Peoples of Latin America," the bishops expressed their belief that "this hiscorical stage of Latin America is intimately linked to the history of salvation." Thus they interpreted that their mission was "to contribute to the integral advancement of man and of human communities in the continent." National Conference of Catholic Bishops Secretariat, The Church in the Present-day: Conclusions, 25 .

$$
\text { See Medelín, Justice, 4-5. }
$$


concerted effort toward "the liberation of all men, the progress of each and all from a less human condition to one more human.": To accomplish this goal, according to

Landázuri, one must understand that "the Kingdom of God will not reach its fullness until integral development has been achieved." -

Three years after Medelin, the second synod of bishops gathered together in Rome and produced a document that linked evangelization with a commitment to the transformation of the world. Avoiding any dualism, the bishops insisted that social justice is inherent in the mission of the church:

Action on behalf of justice and participation in the transformation of the world fully appears to us as a constitutive dimension of the preaching of the Gospel, or, in other words, of the Church's mission for the redemption of the human race and its liberation from every oppressive situation.

Due to the close relationship expressed between spiritual evangelization and social action, this text seems to imply an identification of human progress and the growth of the

:Juan Landázuri Ricketts, "Inaugural Address," in The Church in the Present-Day: Position Papers, 23. In Landázuri's speech there is a direct reference to populorum progressio \$20: "This is what will guarantee man's authentic development--his transition from less than human condition to truly human ones" (Carlen, 5:186).

- Ibid.

"Justice in the World," $\$ 6$, in The Gospel of Peace and Justice, ed. Joseph Gremillion (Maryknoll, NY: Orbis, 1976), 514 . 
Kingdom.: The same implication is found in the final section of the episcopal document where the bishops affirmed that the Kingdom of God is both a gift and a task for all Christians. On the one hand, it states that Christians will find the kingdom as the fruit of their nature and effort at bringing about justice. On the other hand, the bishops described the Kingdom as one of justice and love that God is preparing and "which will be fully perfected when the Lord will come Himself." -

Later in his encyclical Evangelii Nuntiandi (1975),

Paul VI reaffirmed the link between evangelization and social action. He declared that preaching liberation and combating injustice constitute essential elements of

Commenting on this issue, Gremillion notes that the evangelization "is directed toward the inner renewal of man as well as the outward upbuilding of just structures, toward the Kingdom of God where all property, indeed all creation, is held in common with all humankind, in Christ." Joseph Gremillion, "Science's Magnification--and Socialization--of Economic Power," in The Gospel of Peace and Justice, ed. Joseph Gremillion (Maryknoll, NY: Orbis, 1976), 34, emphasis in the original. Likewise, in the document of the 1971 synod ( $\$ 34-35)$. Dorr (Option for the Poor, 186) perceives that one's relationship to God is closely connected to one's relationship to human beings. The bishops rejected that dualism that regards Christianity as spiritual and otherworldly and does not pay much attention to the present situation of the world. In fact, they called Christians to dedicate themselves to human iiberation even in this world ( $\$ 35$ ).

$$
\text { "Justice in the World," \$75 (Gremillion, 529). }
$$


evangelization: In fact, the terms "Kingdom" and "salvation" are seen as the key to understanding Christ's evangelization. These terms are presented in a dialectical way. Both are freely offered to every human being, and, at the same time, each person must gain them." Thus human effort is situated within God's redemptive plan as a contribution to the saving work of God. As Dorr remarks, "human action and divine gift are by no means mutually exclusive." :

Even though the connection between human liberation and salvation in Jesus Christ is established, Paul VI made a distinction between the two. While reminding the church that its mission is to proclaim liberation from all oppression as well as to help the birth of this liberation, the pope made it clear that any progress against oppression

\footnotetext{
"Between evangelization and human advancement-development and liberation--there are in fact profound links." Paul VI, Evangelii Nuntiandi \$ 31 (O'Brien and Shannon, 314). For Paul VI, evangelization has a personal and social dimension involving human rights, peace, justice, development and liberation (ibid., \$ 29).

According to Paul VI (Evangelii Nuntiandi \$ 10), Kingdom and salvation are gained "through toil and suffering, through a life lived according to the Gospel, through abnegation and the cross, through the spirit of the beatitudes." But above all a radical conversion is needed to gain them. He is convinced that those who experience conversion will gather together to seek the kingdom, build it, and live it (ibid., \$13).

Dorr, Option for the Poor, 195.

'Evangelii Nuntiandi \$ 30 (0'Brien and Shannon, 3I4).
} 
should not be regarded automatically as part of God's salvation because above all salvation is a divine gift.: He called the church to give primacy to its spiritual vocation in order to prevent replacing the proclamation of the Kingdom by the proclamation of forms of human liberation.: Consequently, as Paul VI put it, "in order that God's Kingdom should come it is not enough to establish liberation and to create well-being and development," it is also necessary to have a spiritual dimension that embraces justice and charity, and whose goal is salvation and happiness in God.

The Third General Conference of the Latin American Episcopate met in Puebla in 1979. It synthesized the previous teachings about the social doctrine and the Kingdom of God. While Medellin made a few references to the Kingdom, Puebla dealt with it in a broader way. For

\footnotetext{
Ibid., \$ 35, cf. \$ 10 (0'Brien and Shannon, 315, 306). The salvation proclaimed by Christ is regarded as "the great gift of God which is liberation from everything that oppresses man but which is above all liberation from sin and the Evil One" (ibid., \$ 9). Here the meaning of "salvation" embraces as a whole the socioeconomic, political, and spiritual aspects of humankind. Dorr (Option for the Poor, 194) notes that the use of the term "salvation" in this encyclical does not allow an interchange of meaning between "salvation" and "liberation." While the latter is limited to this world, the former transcends the worldly affairs.
}

-Evangelii Nuntiandi § 34 (O'Brien and Shannon, 315).

Ibid., \$35 (O'Brien and Shannon, 315). 
instance, the bishops declared that the Kingdom of God, the heart of Jesus' message, is found "wherever God is ruling through His grace and love, wherever He is overcoming sin and helping human beings to grow toward the great communion offered them in Christ" ( $\$ 226$ ). As such, it is inseparable from the church that transcends its visible limits.:

At the same time, the bishops made it clear that the primary aim of the social doctrine of the church is "the promotion and integral liberation of human beings in terms of both their earthly and their transcendent dimensions." = They perceived this doctrine as a contribution to the construction of the ultimate and definitive Kingdom, while

National Conference of Catholic Bishops, Puebla: Evangelization at Present and in the Future of Latin America: Conclusions (Washington, DC: Committee for the Church in Latin America, 1979), 66. (This work will hereafter be cited as Puebla). Following Vatican II (Lumen Gentium, art. 5), it is stated that the mission of the church is to proclaim and to establish the Kingdom among all peoples (Puebla \$ 227). The bishops kept the tension between distinction and identification of the Kingdom with the church found in Vatican II's documents. While attempting to make a distinction between the Kingdom and the church by presenting the latter as a sign of the former, the bishops at Puebla quoted Lumen Gentium (art. 5) affirming that the church "becomes on earth the initial budding forth of that Kingdom," a seed that needs to grow in history (Puebla \$ 228). Thus, they can say: The Kingdom "has already begun" (ibid., \$ 33I), it "is already here in the church" (ibid., $\$ 229$ ), and it is in the church that "the power that will bring about the definitive Kingdom is already effectively present and at work in the world" (ibid., \$23I). This seems to suggest that the kingdom will be the church made perfect.

-Puebla $\$ 475$. 
warning Christians about any confusion between the growth of the Kingdom and earthly progress.' The bishops wanted to stress that even though the Kingdom passes through historical realizations, that does not mean it is exhausted in them, nor is it identified with them." Thus they confessed not only that the Kingdom has a temporal dimension but also that it is the responsibility of the laity to construct it." They said that

it is in the world that the laity find their specific field of activity. Through the witness of their lives, timely speaking out, and concrete action, the laity have the responsibility of giving order to temporal realities and placing them in the service of the task of establishing God's Kingdom."

$$
\text { Puebla's final conclusions carefully avoided the }
$$

further analyses-economic, social, or political-that would lead to options beyond the evangelizing mission of the church." Nevertheless, evangelization was not understood merely as the announcement of salvation or even a further

Ibid.

- Puebla § 193.

'Puebla \$ 787. A reference to the privileged place of the poor in the Kingdom and Christ's mission is found in Puebla $\$ 1134-65$. The preferential option for the poor. according to archbishop MCGrath, stands out "as the strongest and most characteristic option" of Puebla and of the Latin American church in its evangelizing mission. Marcos McGrath, "The Puebla Final Document: Introduction and Commentary," in Puebla and Beyond, ed. John Eagleson and Philip Scharper (Maryknoll, NY: Orbis, 1979), 109.

\footnotetext{
¿Puebla § 789 .

McGrath, "The Puebla Final Document," 89.
} 
catechesis, but, as archbishop Marcos McGrath remarks, it meant the church's activity that "aims at the full transformation of human beings (prayers, sanctity) in christ and of society, in the communion and participation of the church." :

At the Puebla Conference, Pope John Paul II (1978-) faced a crucial question: Is the Roman Catholic Church in Latin America marching towards social justice in this world, or is it seeking only liberation and salvation in the next? In his opening address to the Conference, the pope insisted that religion and politics are separate. The former must remain a transcendent value, free from ideological attempts to exploit it in the economic and political sphere.

At the very beginning of the Puebla Conference, John Paul II criticized and opposed the "re-readings" of the gospel. He qualified them as being the result of "theoretical speculations rather than of authentic meditation on the word of God and a genuine evangelical commitment" (I, 4).: He also pointed them out as the cause

Ibid., 110.

-James V. Schall, "The American Press Views Puebla," in The pope and Revolution, ed. Quentin L. Quade (Washington, DC: Ethics and Public Policy Center, 1982), 9596. CE. David Willey, God's Politician (London: Faber and Faber, 1992), 116 .

John Paul II, "Opening Address at the Puebla Conference," in Evangelization at Present and in the Future of Latin America: Conclusions, ed. National Conference of Catholic Bishops (Washington, DC: Committee for the Church 
of confusion by their departure from the central criteria of the faith of the church.: Particularly, the pope opposed those interpretations that depict Jesus as a political activist involved in class struggle and fighting against Roman domination. This representation of Jesus, according to John Paul II, "does not tally with the church's catechesis" (I, 4):

In his attempt to correct these "re-readings" of the gospel, the pope referred to the mission of the church, namely to send evangelizers not to manipulate the gospel according to their personal ideas but to evangelize "in communion with the church and its pastors" (I, 7)." Due to their close connection, a distorted notion of the nature and mission of the church will lead to an incorrect perception of the Kingdom and vice versa.; Thus John Paul II opposed the understanding of the kingdom in a secularist sense because it limits the Kingdom to structural change or to the

in Latin America, 1979), 3.

Ibid.

- Ibia.. i.

Ibid.. 6. Here John Paul II is quoting Paul VI's Evangelii Nus:_a.s: $\& 60$.

'By' guozing the teachings of Vatican II, John Paul II reaffirmed that the church and the kingdom are not separable, that the church "becomes the initial budding forth" of the kingoiom and that its mission is to proclaim and establish among all peoples the kingdom (Lumen Gentium, 5). John Paul II, "Opening Address," I, 8. 
socio-political sphere. This, in turn, reduces the mission of the church to the changing of social or political structures (I, 8): Using the words of his predecessor, the pope reminded the bishops that it is wrong to identify the regnum Dei with the regnum hominis ( $I, 8) .^{2}$

A few years later, echoing John Paul II's criticism, the Congregation for the Doctrine of the Faith strongly condemned liberation theology as a whole for its tendency "to identify the Kingdom of God and its growth with the human liberation movement and to make history itself the subject of its own development, as a process of selfredemption of man by means of the class struggle." $"$ This

John Paul II, "Opening Address," 6. See Carlos Ignacio Gonzalez, "La teología de la liberación a la luz del magisterio de Juan Pablo II en América Latina," Greg 67 (1986): 5-46; cf. Virgilio Elizondo, "The Pope's Opening Address: Introduction and Commentary," in Puebla and Beyond, ed. John Eagleson and Philip Scharper (Maryknoll, NY: Orbis, 1979), 50 .

-John Paul II, "Opening Address," 6. The bishops incorporated into the final document John Paul II's remarks about the re-readings of the gospel and the secular interpretations of the Kingdom. See Puebla \$ 358-61.

Congregation for the Doctrine of the Faith, "Instruction on Certain Aspects of the Theology of Liberation," $X, 3,4$. In this official document issued in 1984, Iiberation theology was accused of historical immanentism and of reducing the Christian gospel to a social program (ibid.). Liberation theologians, including Gutiérrez, were criticized for adopting the class struggle, a term that "remains pregnant with the interpretation that Marx gave it" (ibid., VII, 8). The Vatican Instruction accepted the fact that a social conflict exists, but rejected that this conflict be analyzed as if it were a class struggle (ibid.. IX, 2). Furthermore, the Instruction maintained that the use of expressions such as class 
notion is considered in opposition to the teachings of Vatican II.

John Paul II's most detailed treatment on the Kingdom may well be found in his Redemptoris Missio (1990)." In this document, the pope repeated from a Christ-centered perspective most of the teachings of Vatican II and the social doctrine of the church regarding the Kingdom.: The

struggle causes confusion in the mind of the readers of liberation theology (ibid., VII, 8).

John Paul II, "Redemptoris Missio," in The Encyclicals of John Paul II, ed. J. Michael Miller (Huntington, IN: Our Sunday Visitor, 1996), 493-570. Hereafter cited as Miller. Other references to the Kingdom are found in John Paul II's following encyclicals: Laborem Excersen (1981) states that work is necessary for the earthly progress and the development of the Kingdom ( $\$ 131$ [Carlen, 5:325]). Redemptoris Mater (1987) states that Mary has a share in the Kingdom (\$ 41.4 [Miller, 398]). Sollicitudo Rei Socialis (1987) says that our present history is open to the Kingdom ( $\$ 47.1$ [Miller, 473]), that no temporal achievements are to be identified with the Kingdom, that they are only an anticipation of the ultimate Kingdom of God. On earth the kingdom is already present in mystery, above all in the Eucharist. This sacrament both anticipates the Kingdom and proclaims its final coming ( $\$$ 48.1-48.5 [Miller, 475-76]). Veritatis Splendor (1993) refers to the Kingdom in terms of "eternal life" which is attained in its perfection only after death ( $\$ 12.2$ [Miller, $683-84])$.

-Miller, 504-11. It is said that the Kingdom is the center of Jesus' preaching. His mission was the proclamation and establishment of the Kingdom (13.1). In fact, He came to inaugurate it (13.3, cf. 16.1) and to reveal its characteristics and demands through His words, actions, and His own person (14.1, cf. 18.2). Therefore, the Kingdom is not relegated to the end of the worldi it is already present among human beings (13.2). John Paul II insisted that while Christ, the Kingdom, and the church are distinct, they remain "indissolubly united" (18.3). As such, "the Kingdom cannot be detached either from Christ or 
Kingdom is defined above all as "a person with the face and name of Jesus of Nazareth,": who calls all people to become members of it through faith and conversion." Likewise, the nature of the kingdom is interpreted as one of just and loving relations among human beings, with one another and with God:' Moreover, the Kingdom is seen as God's gift and work. As such, it is one's duty to ask for it, welcome it, and make it to grow within oneself. But, at the same time, human beings must work together so that it will be welcomed and will grow among all people, until the time of its

the church" (18.1). To separate the Kingdom from Christ not only is a misrepresentation of its meaning, "which runs the risk of being transformed into a purely human or ideological goal, " but also is a distortion of Christ's identity, "who no longer appears as the Lord to whom everything must one day be subjected" (18.2). The church cannot be separate from the kingdom because it is the seed, sign, and instrument of the Kingdom (18.3). Moreover, the church is not an end in ieself (19), but it is at the service of the Kingdom by its preaching $(20.1)$, by establishing communities and guiding them to mature faith and love in service to individuals and society $(20.2)$, by spreading the gospel values-an expression of the Kingdom--everywhere (20.3), and by its intercession (20.5). In short, the church works and prays for the perfect and definitive realization of the Kingdom (12.1).

John Paul II, Redemptoris Missio \$ 18.2 (Miller, 508), emphasis in the original.

-Redemptoris Missio \$ 14.2, 13.2. The pope recognizes that the growth of the Kingdom affects both the physical and spiritual dimensions of every human being ( $\$$ 14.3) and that eschatological salvation begins even now in newness of life in Christ (\$ 20.1) (Miller, 505-6, 509-10).

According to John Paul II, "the Kingdom aims at transforming human relationships, it grows gradually as people slowly learn to love, forgive and serve one another." Ibid., \$15.1 (Miller, 506). 
ultimate realization.: Thus the growth of the kingdom is described not in terms of social or political liberation, but in terms of new social relations of solidarity that come as a result of God's love reigning among all human beings. One notes an emphasis in God's activity in the transformation of individuals and society:

The Kingdom is the concern of everyone: individuals, society, and the world. Working for the Kingdom means acknowledging and promoting God's activity. which is present in human history and transform it. Building the Kingdom means working for liberation from evil in all its forms. In a word, the Kingdom of God is the manifestation and the realization of God's plan of salvation in all its fullness.

Aware of the different misconceptions about the Kingdom, John Paul II mentioned particularly two views that are considered doctrinally erroneous. First, there is a secular interpretation of the Kingdom that gives primacy to socioeconomic, political and even cultural liberation. This view easily translates the Kingdom into "one more ideology of purely earthly progress.": Second, there is a theocentric understanding of the kingdom which is silent about Christ and leaves little room for the church. This view, according to John Paul II, fails to see that the Kingdom is "not a concept, a doctrine, or a program subject to free interpretation, but it is before all else a person

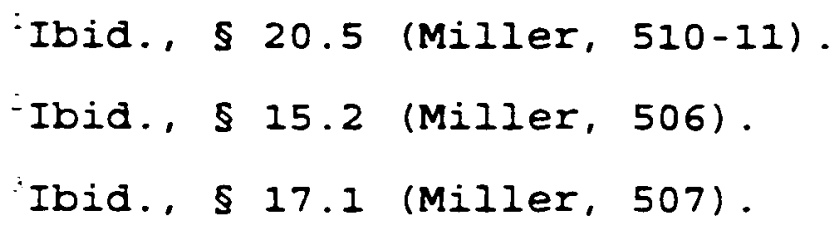


with the face and name of Jesus of Nazareth.": In his attempt to correct these misunderstandings, the pope opted for a definition of the Kingdom based on Scripture and the official teaching of the church. He emphasized that the Kingdom is indissolubly united to Christ and the church. It cannot be separated from them.:

In synthesis, since vatican II, a new period of theological thought has begun within the Roman Catholic Church. It has become aware that its evangelizing mission encompasses not only personal salvation but also the transformation of this world. By calling its teachers and theologians to engage in dialogue and collaboration with those "well versed in other sciences," "the council opened the door for the use of social scientific theory in the development of theology within Roman Catholicism.

On the other hand, the post-conciliar social doctrine preserves the tension, already present in vatican II, between conservative and progressive Roman Catholics regarding the role of Christians in the world. While the former want to keep the church separated from politics, the latter want to involve the church in the process of liberation from sin and its socioeconomic and political original.

Ibid., \$18.2 (Miller, 508), emphasis in the Miller, 482. (Abbote, 270). 
consequences. While the former emphasize the spiritual dimension of the Kingdom, the latter are more concerned with the building up of the Kingdom in its temporal dimension. However, both groups agree that earthly progress should not be confused with the growth of the Kingdom.

\section{Summary and conclusion}

The Second Vatican Council explained the notion of the Kingdom in a Elexible language that pleased both progressives and conservatives within Roman Catholicism. The general formulas used in crucial statements allow for further theological elaboration. The conciliar teaching on the Kingdom of God reflects the thinking of progressive Catholic theologians, especially in the call for Christians to participate in the transformation of the world so that the Kingdom may be partially realized in history, and in the distinction of the Kingdom and the church where the latter should serve the Kingdom instead of taking its place. This progressive trend is also noticed in the insistence that the proclamation of the Kingdom affects all relationships that call people to reorder their societal and personal relations.

At the same time, the council follows the traditional tendency to identify the kingdom with the church as well as the growth of the Kingdom with the growth of the church. On this issue there is a lack of clarity. In order to safeguard the eschatological Kingdom as the absolute, the 
socioeconomic and political order is regarded as relative. Hence, efforts are made to avoid any connection between the Kingdom of God and human liberating activity.

The same ambivalent language is found in postconciliar social doctrine. It depends on the kind of lens one uses to read papal encyclicals and pronouncements as well as the episcopal conferences to find either progressive or conservative elements.

There have been several major events in the postconciliar development of the social doctrine. Medellin reformulated the role of Christians in socio-political cerms. The 1971 Synod of bishops and Paul VI's Evangelii Nuntiandi linked social justice and evangelization. This in turn opened the door to the temptation for the church to meddle in politics. But John Paul II has curbed this temptation by emphasizing that Christian commitment to liberation must not be understood in primarily socioeconomic and political terms. By highlighting the conservative elements in the official teaching of the church, the pope has provided a more scripture-based definition of the Kingdom of God and its intrinsic connection with Jesus and the church. 
CHAPTER V

\section{SUMMARY AND CONCLUSION}

The investigation of Gustavo Gutiérrez's and Vatican II's view on the Kingdom of God set forth in the preceding chapters has provided enough elements to perceive Gutiérrez's agreements and divergences with the conciliar documents. The aim of the present chapter is to present a comparative and evaluative analysis of Gutiérrez's understanding of the Kingdom of God in the light of the documents of the second vatican council.

Before evaluating Gutiérrez's view on the Kingdom, an assessment of his methodology is needed to understand his viewpoint.

\section{Hermeneutical Considerations}

The Second Vatican Council opened the door for a theological reflection that, in a more direct way, incorporated the historical dimension of humanity and the mission of men and women in the world. Faith, traditionally perceived mainly as a speculative function that accepts truths, was also regarded by the council as an option that 
takes into consideration all the dimensions of human life.: This new attitude towards the world came as a result of the introduction of progressive elements into the traditional teaching of the Roman Catholic Church. This, in turn, led the council to adopt an ambivalent tendency. While the participants at Vatican II revealed an inflexibility and an adherence to the traditional deposit of the faith, there was an openness, within certain Iimits, to some reinterpretations by progressive Roman Catholic theologians. Among other things, their emphasis was on the servant Eunction of the church and its social responsibility toward the poor. On one hand, the concern for the poor gave an impetus to a quest for justice. On the other, their emphasis on the role of the church as servant implied a denunciation of institutionalism and triumphalism, a marked pre-conciliar attitude of the Roman Catholic Church.

$$
\text { Gutiérrez's theology seems to follow the same }
$$
approach characterized by its ambivalence. While striving to be faithful to the teachings of the council, he attempts to transcend them. Gutiérrez does this by introducing some new elements into his theology. First of all, history (i.e., the process of political liberation) is introduced as

For instance, in Gaudium et spes, the council attempted to respond to the challenges that humanity faces in its daily life. It is said that redemption is not limited to the sphere of the supernatural but affects all dimensions of life. "The Pastoral Constitution on the Church in the Modern World," art. 43 (Abbott, 243-45). 
a criterion of biblical interpretation. Second, it is suggested that the Scriptures should be reread in the light of history: Next, the poor are regarded as an hermeneutical key to understanding history.' Finally, the social sciences, in particular Marxist social scientific categories such as praxis and class struggle, are used as a tool to understand Latin American social reality. These methodological presuppositions, together with the preferential option for the poor, led Gutiérrez to define theology as a reflection of the Christians' engagement in the liberating praxis.: Our author is more concerned with the liberating praxis than with the theory of becoming Christians:

The use of history as a criterion of biblical reinterpretation led Gutiérrez (A Theology, 155-59) not only to see the Exodus as a political event, a political liberation in which the oppressed people played an active role, but also to consider the Exodus experience as paradigmatic for Latin Americans.

The significant shift toward the world brought by Vatican II is interpreted by Gutiérrez as if it applied only to the poor. He consistently develops his theology through the eyes of the poor who are perceived preeminentiy in a Marxist fashion as "the oppressed one, the one marginated from society, the member of the proletariat strugging for his most basic rights" (A Theology, 301).

As Christine E. Gudorf (Catholic Social Teaching [Lanham, MD: University Press of America, 1980], 60) correctly notes, theological reflection is used to guide an ongoing praxis whose reflection results in new theology which, in turn, continues to correct and guide praxis.

'In a similar vein, Miguez-Bonino's concern is not whether the Kingdom is present or visible in today's history, but how one can participate in the realization of 
In contrast with traditional Roman Catholic orthodoxy, which holds that the pastoral activity of the church flows from its theological premises, Gutiérrez maintains that theology reflects upon pastoral activity. Since his basic presupposition is that theology should begin with the historical situation, what guides the elaboration of his theology is the Latin American reality rather than the scriptures.

Gutiérrez is not alone in the use of social reality as a context to do theology. It is a tool adopted by liberation theologians such as Juan Luis Segundoi and Hugo Assmann.- Here, Gutiérrez seems to have followed Yves Congar's notion regarding the openness of the church to the world. According to Congar, if the church wants to respond to the real questions of modern society, Roman Catholic theologians must start their theological work by not only

the coming world either as an individual or as a community. Miguez-Bonino, Doing Theology in a Revolutionary Situation, 143 .

In his hermeneutical circle, segundo argues that the scriptures should be interpreted in the light of "the continuing changes in our present-day reality, both individual and societal." Juan Luis Segundo, The Liberation of Theology, trans. John Drury (Maryknoll, NY: Orbis, 1976). 8 .

-"The usual perspectives of the exegetes who 'work from the sacred text' no longer satisfy us, since we want to 'work from the reality of today.'" Hugo Assmann, OpresiónIiberación: desafío a los cristianos (Montevideo, Uruguay: Tierra Nueva, 1971), 141. 
using revelation and tradition but also through facts and questions derived from the world and from history.:

Without regarding the conditions of oppression and poverty irrelevant, Vatican II made it clear that the interpretation of the scriptures is by no means to be governed by any historical situation. To do this is to relativize the Word of God since its meaning will vary when the social context changes. Instead of interpreting the Scriptures from the context of social analysis, the council recommended that it should be done from the scriptures' own inner context.: It reminded the theologians that the Scriptures and tradition are the "primary and perpetual foundation" of their theological work." Together they are the basis of every truth.:

Gutiérrez challenges this conciliar teaching by claiming that truth is neither existent nor verified apart from Christian praxis. This assumption envisions the Christian praxis as a source of truth. For this reason, Gutiérrez has been accused by the Congregation for the

Yves Congar, Situations et tâches présentes de la théologie (Paris: Les Éditions du Cerf, 1967), 72, quoted in Gutiérrez, A Theology, 12.

12 (Abbott, 120-21).

"Dogmatic Constitution on Divine Revelation," art.

Ibid., art. 24 (Abbott, 127).

"The council regarded the scriptures and tradition "as the supreme rule of Eaith." Ibid., art. 21 (Abbott, 125). 
Doctrine of the Faith of attempting to replace the word of God with the concept of praxis, a notion regarded as incompatible with the Catholic faith.:

In short, what remains problematic is Gutiérrez's view that God's saving activity and Christians' liberating praxis are informed by the existing social and political conditions in which the Latin American poor live rather than by a biblical perspective.

\section{Gutiérrez's New Approach to Theology \\ Gutiérrez's hermeneutics is in a sense a reaction to} an abstract European theology that predominates within Roman Catholic as well as Protestant circles. He admits that his theology is more a new approach to contemporary problems than a new way of thinking, an apprcach influenced by the experience of the Latin American context. Hence our author claims originality primarily in two aspects of liberation theology: (1) its methodology, and (2) its insistence on

:See Congregation for the Doctrine of the Faith, "Instruction on Certain Aspects of the 'Theology of Liberation, " VII, 1-9. The Instruction (X, 3 ) denies that praxis--"revolutionary praxis"--is a criterion for the truth. Instead, it is affirmed (VII, 10) that "the ultimate and decisive criterion for the truth can only be a criterion which is itself theological." Likewise Durand (Observaciones, 113-30) criticizes Gutiérrez's attempt to place revolutionary praxis as a locus theologicus. Although Durand admits that the locus theologicus is a help to the sources of revelation and the magisterium, it is not in itself a source of revelation (ibid., 127). For Durand, a criterion for the truth must be based on God and His revelation (ibid., 125-26). 
God's preferential love for the poor as the center of reflection on the gospel.:

Gutiérrez gives theology a new meaning. It should not concentrate primarily on defending eternal and unchanging truths, but on the conditions in which the poor live. He advocates a theology that comes from reflecting on liberating praxis, a theology whose task is to participate creatively in the process of change going on in history. In other words, he argues that theology should be more practical than speculative." The Peruvian theologian seems to take into consideration at least two elements of Gaudium et spes to support his conclusion. First, the conciliar document encourages Christians to take an active part in the struggle against exploitation and poverty, as well as to contribute "to the prosperity of mankind and the peace of the world." Second, Gutiérrez emphasizes that part of the statement that refers to the earthly progress as of "vital concern to the Kingdom of God."

See Gutiérrez, "Two Theological Perspectives," 247 48; idem, "Reflections from a Latin American Perspective," 225-26; idem, "Speaking about God," in Different Theologies, Common Responsibiijty: Babel or Pentecost?, ed. Claude Geffré and Gustavo Gutiérrez, and V. Elizondo (Edinburgh: $T$. \& T. Clark, 1984), 28-30. See also pp. 60-66 above.

-See pp. 66-69 above.

"The Pastoral Constitution on the Church in the Modern World," art. 72 (Abbott, 282).

Ibid., art. 39 (Abbott, 237). 
In his attempt to change from reflecting on the abstract to reflecting on the concrete, Gutiérrez challenges the way Vatican II interpreted the sacred deposit entrusted exclusively to the magisterium of the church: because the latter favors the status quo. This interpretation is regarded as too abstract and one-sided and, as such, prevents Latin American believers from being involved in the transformation of the world. Instead of a merely spiritual interpretation of the scriptures or a reading from the perspective of those in power, the Peruvian theologian proposes a militant reading of the word of God from the perspective of the oppressed.

\section{Gutiérrez and the New Human Being}

The emergence of a "new humanism" already acknowledged at Vatican II is another foundation of Gutiérrez's theology. Due to his concern with the poor, and aware that in Gaudium et spes the centrality of human beings and their concerns is an overriding theme, ' Gutiérrez places

"Dogmatic Constitution on Divine Revelation," art. 10 (Abbott, 117-18); "Decree on the Missionary Activity of the Church," art. 22 (Abbote, 612). Cf. "Instruction on Certain Aspect of the "Theology of Liberation," III, 4 ; VI, 7 .

- All things on earth should be related to man as their center and crown," declared the bishops at the council, and "through him raise their voice in free praise of the Creator" ("Pastoral Constitution on the Church in the Modern World," arts. 12, 14 (Abbott, 210, 212]). The council encouraged human beings everywhere to participate in public affairs and to contribute to the realization, in 
man at the center, from the beginning to the end of his theological enterprise. His theology aims at the creation of a new person: who takes the reins of its destiny.

The commitment to the formation of a new human being in a new society again led him to a shift from a theology focusing on a transcendent God revealed in His word to one in which human beings and their world are the focus of attention. In this shift, one finds a basic variance from the documents of Vatican II. The difference is in the emphasis; while the council mainly placed emphasis on God, our author placed stress on man to the point that he could say that God is found in man.

Still, the new person to whom Gutiérrez referred is not the same "new man" depicted by the apostle Paul.: Rather, it is a concept understood in terms of socioeconomic categories based on Marx's philosophy and Che Guevara's

history, of God's plan (ibid., arts. 31, 34 [Abbott, 229, 232]).

Ibid.. 145-46, 189. Because Gutiérrez does not clarify who this "new man" is and how is he originated. Durand (Observaciones, 56-58) assumes that the Peruvian theologian believes that social structures create the "new man." In an interview, Gutiérrez rejected that assumption and made it clear that it is not enough to change the social structures. If there is no change in the person, the social structures become oppressive. In other words, it is the man who affects and changes society, and not vice versa. Interview by author, January 28, 1997, Lima.

$$
\text { CE. Titus } 3: 3-7 ; 2 \text { Cor 5:17-18. }
$$


thought.: One should not infer from this that Gutiérrez has little room for Paul's concept as understood by Vatican II. Basically, both agree that Paul's "new man" is one whom God transforms and who, as a consequence, transforms the society he lives in, not vice versa. Both concur that human beings who are enslaved by the devil and sin are made free by Christ's redemptive activity. Christ makes possible for "the whole man" to be "renewed from within." = The basic difference between the council's and Gutiérrez's concept of the new man seems to arise from his use of social sciences and the notion of liberation he upholds.

It seems that, for him, the "new man" to be created by liberating praxis and the Pauline "new man" belong to two different levels of Iiberation. The former corresponds to the second level of Gutiérrez's tridimensional approach and is man's work, while the latter is fulfilled in the third level and is God's work."

\section{Gutiérrez and Social sciences}

The use of social sciences, in particular the use of social Marxist analysis, is fundamental to Gutiérrez's new model of theological interpretation. It helps him not only

See Gutiérrez, A Theology, 29-30, 38, n. 12, 91.

- "Pastoral Constitution on the Church in the Modern World," art. 22 (Abbott, 221). A similar stance was adopted by Medelin in its document "Peace," 1.

See above pp. 108-13. 
to understand the Latin American situation but also to see the need for a radical change of the social structures. Moreover, it leads him to speak of liberation and not of developmentalism, and of social revolution instead of reform.

The question is whether it is possible to remain faithful to the official Roman Catholic teaching by bringing theology and social sciences into relationship with each other and by using social Marxist analysis as a hermeneutical tool. Gutiérrez answers positively because he is convinced that social sciences are in dialogue with theology. Hence, in his theology, both social transformation and spirituality are kept tied together.: In fact, our author makes a continued effort for keeping social analysis and liberating praxis in balance with religious belief and practice.

The use of social Marxist analysis by Gutiérrez seems to be a logical reaction to a by-product of his criticism that Vatican II neglected a detailed investigation and analysis of the social reality of the contemporary world. Through this omission, the council failed to address the real problems challenging the Christian faith in the

See pp. 50-56, 61-65, 163-65 above.

-Gutiérrez (We Drink, 2, 29) argues that a new spirituality is "now being born" among Latin American poor. where hope plays an important role moving human action towards the future. 
Third World, particularly in Latin America.: However, our author seems to forget that the purpose of Vatican II was not to solve specific problems faced by a country or region in particular. Rather, the council proposed general principles and hoped that its proposals would be "adapted to individual nations and mentalities by the faithful, under the guidance of their pastors." = Indeed, Vatican II wished to cooperate in the solution of numerous problems in the contemporary world. The bishops were concerned, among other things, with the emergence of new forms of social and psychological slavery. ${ }^{3}$

Gutiérrez argues that his use of social Marxist analysis does not mean the endorsement of Marxist dialectical materialism. He usually compares the use of Marxist analysis with the use of Freud's principles in psychology. He contends that one is not a Freudian merely because he or she uses the categories advanced by Freud, hence, it is wrong to label Marxist those who use the categories proposed by Marx, particularly the notion of

See Gutiérrez, "Church of the Poor," 12-13. The Peruvian theologian suggests that it is easy to understand why poverty and the evangelization of the poor were largely neglected in Vatican II, because the majority of bishops and experts came from rich and developed countries (ibid., 13).

- The Pastoral Constitution on the Church in the Modern World," art. 91 (Abbott, 305).

Ibid., art. 4 (Abbott, 202-3). 
class struggle: Marxist categories correspond to the social conditions in Latin America where society is divided into two hostile groups "directly facing each other-bourgeoisie and proletariat," = and deserve therefore to be retained.

To no one's surprise, the adoption of Marxist elements has raised strong criticism against Gutiérrez's theology among Roman Catholics' and Protestants as well."

Interview by author, January 1994. Juan Luis Segundo admits the Marxist influence in liberation theology. Regardless of whether or not one accepts all that Marx said, there is no question that "present-day social thought will be 'Marxist' to some extent: that is, profoundly indebted to Marx. In that sense Latin American theology is certainly Marxist." Segundo, The Liberation of Theology, 35, n. 10.

- Karl Marx, Communist Manifesto, with an introduction by Stefan Possony (Chicago: Henry Regnery Co.. 1954), 13-15.

See Durand, Observaciones, 23-104; idem, Utopía de Ia Liberación, 24-30, 65-167; López-Trujillo, De Medellín a Puebla, 226-36. Because Marxism contains atheism as one of its essential elements, conservative Roman Catholic theologians regard any Iink of their faith with Marxist ideology as a distortion of theology. For instance, Alfredo Fierro, The Militant Gospel (London: SCM Press, 1977), 324, doubts that Gutiérrez's A Theology of Liberation is a theology at all. Instead Fierro considers it as a testimony of the condition of life of the poor in Latin America. An overview of the critics of Iiberation theology is found in Arthur F. MCGovern, Liberation Theology and Its Critics (Maryknol1, NY: Orbis, 1989), 47-61.

'Clark Pinnock notes that in Gutiérrez's theology one gets the impression that biblical theology has been relegated to a second place, while political analysis has taken precedence. "Liberation Theology: The Gains, the Gaps," ChrToday (January 16, 1976): 15. Emilio Núñez, Liberation Theology (Chicago: Moody Press, 1985), 143, in a similar vein, remarks that as a result of the influence of 
To what extent can one use Marxist social analysis without accepting the entire Marxist ideology that promotes atheism and a totalitarian society? Pope Paul VI in his encyclical Octogesima adveniens (1971) warned Roman Catholics about this risk. He explained,

it would be illusory and dangerous. . . to accept the elements of Marxist analysis without recognizing their relationships with ideology, and to enter into the practice of class struggle and of its Marxist interpretations, while failing to note the kind of totalitarian society to which this process leads.

Quoting Octogesima adveniens $\$ 34$, the Puebla

Conference (1979) also questioned the possibility of separating social Marxist analysis from Marxist philosophy of man and history.- Moreover, Puebla warned about the risk of ideologization of the theological reflection when it

Marxist analysis with its praxis for social change, Gutiérrez's thought became subordinated to sociology and liberating praxis. For his part, Carl Braaten perceives the term praxis to be a "Marxist load" of meaning incompatible with the gospel. Carl E. Braaten, "Praxis: The Trojan Horse of Liberation Theology," Dial 23 (1984): 276. See Stephen Knapp, "A Preliminary Dialogue with Gutiérrez' A Theology of Liberation," in Evangelicals and Liberation, ed. Carl E. Armerding (Phillipsburg, NJ: Presbyterian and Reformed Publishing Co., 1979), 17-18; Kenneth Hamilton, "Theology: Lessons Positive and Negative," in Evangelicals and Liberation, 120-27. For a useful study of the most significant North American responses to Latin American liberation theology see Craig I. Nessan, Orthopraxis or Heresy (Atlanta, GA: Scholars Press, 1989), 223-339, 356-58.

Paul VI, Octogesima adveniens \$ 34 (Paul VI, The Teachings of Pope Paul VI-1971 [Vatican City: Libreria Editrice Vaticana, 1972], 361).

- Puebla $\$ 544$. 
starts from a praxis that makes use of the social Marxist analysis.:

Vatican II likewise had warned Roman Catholics about modern atheism that opposes any kind of dependence on God. Avoiding an explicit mention to Marxism, the council rejected any atheistic ideology that perceives human beings as the only artisans and creators of their own history without any dependence on a higher being. Alluding to a distinctive tenet of Marxist ideology, the council identified as one of the forms of modern atheism that "which anticipates the liberation of man especially through his economic and social emancipation."

Given the council and post-council documents' warning, what motivates Gutiérrez's use of Marxist tools? Aware of the struggle of those believers who have adopted a

'Puebla $\$ 545$. Having in mind the Octogesima adveniens $\$ 34$, the late Pedro Arrupe, Jesuit Superior General, wrote that the adoption of the Marxist analysis as a whole is not acceptable because it is too difficult, if not impossible, to separate the Marxist analysis from historical materialism. Pedro Arrupe, "Marxist Analysis by Christians," Or 10 (April 16, 1981): 692. See above pp. $168-73$.

- "Pastoral Constitution on the Church in the Modern world," art. 20 (Abbott, 217-18). From what we have seen thus far, it seems to be clear that Vatican II and the postconciliar documents did not endorse the use of social Marxist analysis. This tool is inadequate for several reasons. First, it does not take into serious consideration that the world and temporal activities are affected by sin. Next, the social Marxist analysis tends to stress a more optimistic view about human achievement. Finally, it fails to take into account the cosmic dimension of the conflict between good and evil as presented in the scriptures. 
Marxist view of society, our author wants to help them see the Christian's role within a system of legal oppression.

One should keep in mind that Christianity and Marxism have often been at odds with each other. Marxists have criticized the role of religion in society. They saw it as a hindrance in the transformation of society. Their objections were directed against Christian hope because it made Christians passive spectators. One major objection against Christianity was that Christians did not see the need to be engaged in the work of transforming this world because their hope was set on another one.

Both the council and Gutiérrez have attempted to cope with Marxist criticism. The council made it clear that the Christian message does not prevent men and women from building up the world. On the contrary, Christians, by their work, "are unfolding the Creator's work . . and are contributing by their personal industry to the realization in history of the divine plan.":

on his part, going beyond the council, Gutiérrez sought a form of convergence of Christianity and Marxism. This midale ground is found in his liberation theology where these two traditions are no longer mutually exclusive. Thus, human beings are seen as the artisans and creators of their own destiny while still dependent upon God.:

\footnotetext{
Ibid., art. 34 (Abbott, 232-33).

See above pp. 51, n. 3, 56.
} 
Likewise, human Iiberation from all forms of alienation is regarded as part of the first level of liberation which needs to be complemented with the liberation from sin, a divine work described as part of the third level.: Thus Gutiérrez's theology makes it possible for Christians and Marxists to work together in the transformation of society. But the price paid for this theological quest is the reduction of the Christian faith to a kind of revolutionary political action.

Despite Gutiérrez's denial that his theology is Marxist, a strong criticism of his liberation theology came from the Congregation of the Doctrine of the Faith." As a result, in his effort to remain in good standing with his church, Gutiérrez made some changes in the second English edition of his $A$ Theology of Liberation." In response to those who criticize him for using the social Marxist analysis, our theologian recognizes the need for refining the analytical tools and for developing new ones. He now admits that the theory of dependence is at the present time an inadequate tool, "because it does not take sufficient account of the internal dynamics of each country or the vast

See above pp. 109-13.

see above p. 173, n. 3 .

Gustavo Gutiérrez, A Theology of Liberation, 2d ed. (Maryknol1, NY: Orbis, 1988). 
dimensions of the world of the poor.": Even more, in order to clarify some misunderstandings of the first edition of his classic book (1971), Gutiérrez asserts that he has rewritten it in the light of new documents of the magisterium. -

In spite of these changes the question persists as to whether Gutiérrez has changed his mind. Was this merely a cosmetic change? In an interview in November 1993, he recognized that if he had to write his $A$ Theology of Liberation again, he would do it differently, not because his fundamental thought has changed, but because, in the passing of time, a person matures and distinguishes more clearly the essential from the accessory." In addition, he refers to new important documents of the magisterium which guide Roman Catholic theologians in the way they should do theology:- Clearly Gutiérrez has learned from the criticism

Ibid., xxiv.

This new edition has a new introduction entitled "Expanding the View" where Gutiérrez shows a conciliatory spirit and claims that what he stands for is in basic agreement with the official teaching of his church. Among other things, he expands his view of the poor and the oppressed to include racism, sexism, and any other forms of oppression. Moreover, he admits overemphasis on the political aspect of liberation (ibid., $x-x l v$ ). To avoid further misunderstandings, our theologian refers to "social conflict" rather than "class struggle" (ibid., 156).

"Entrevista de Ideele a Gustavo Gutiérrez," Ideele 58 (November 1993): 21 .

'Ibid. Even his detractors perceive Gutiérrez's effort to be faithful to his tradition. For instance, 
leveled at his theology by the Roman Catholic hierarchy. He has shown his work to be in harmony with the official teaching of his church.

Under the Marxist influence, Gutiérrez has

challenged the teachings of Vatican II by embedding some Marxist principles, such as praxis and social Marxist analysis, within the context of faith and of the community of faith. To alleviate the tension between his theology and the teachings of the magisterium, he has come to soften his language and has changed the accents on the issues he deals with, but the essence of his thought remains the same.:

\section{Vatican II, Gutiérrez, and the Kingdom of God}

The collision between conservative and progressive Roman Catholic theologians at the Second Vatican Council opened the door to various interpretations of the Kingdom. Conservative theologians, who favor the discontinuity between history and the Kingdom, conceive the latter as merely a divine gift to be fully realized at the parousia, and, consequently, the Kingdom cannot be made even partially by human effort. In contrast, progressive theologians, who

Ricardo Durand (Observaciones, 12) notes that if the Peruvian theologian had had the present documents of the magisterium, he might have written his classic book differentiy.

'See Gutiérrez, The Truth, 41.

- See above pp. 143-51. 
favor the continuity between history and the Kingdom, tend to emphasize the necessary involvement of human beings, either Christians or non-Christians, in the building of a better world. For them, human contribution is necessary for the realization of the Kingdom of God.

Both trends see in the documents of Vatican II support for their viewpoints on the Kingdom. By choosing to follow the lead of the progressive position, Gutiérrez saw in Vatican II an open door to reflect on the Kingdom as liberation where human participation is foundational. Likewise, to avoid a direct confrontation with Roman Catholic hierarchy in the development of his theology, Gutiérrez not only capitalized the tension between conservative and progressive Roman Catholic theologians but also used the consensual approach of Vatican II as a paradigm.

\section{Liberation-Salvation}

The Second Vatican Council clearly distinguishes between the spiritual and the temporal orders. As a result, the council prefers to speak of salvation as distinct from socioeconomic and political liberation. However, the distinction between these two orders does not rule out their close connection to each other in "the one plan of God.": Christ's salvation is regarded as the liberation from the

Second Vatican Council, "Decree on the Apostolate of the laity," art. 5 (Abbott, 495). 
devil and sin," which "involves also the renewal of the whole temporal order." = To admit that the historical reality is affected by Christ's salvation does not mean that the council considers the restoration of the temporal realm as a salvific event, as held by Gutiérrez, but as a Christian responsibility to build a better world where justice, characteristic of God's Kingdom, may prevail." While Vatican II stresses the distinction of the spiritual and temporal order, Gutiérrez, on his part, emphasizes their close connection. As mentioned earlier, Gutiérrez regards salvation not as purely eschatological, but as including a historical dimension where human beings are set free from all kinds of oppression, whether socioeconomic, political, or spiritual.' Due to the insistence that salvation can be experienced in the here and now of history, Miguel Manzanera rightly observes that Gutiérrez's theology of salvation can also be called a theology of liberation. It is not a mere linguistic change. but reflects the new way of doing theology."

\footnotetext{
"Pastoral Constitution on the Church in the Modern World," art. 22 (Abbott, 221).

-Second Vatican Council, "Decree on the Apostolate of the Laity," art. 5 (Abbott, 495).

Ibid., art. 7 (Abbott, 497-98).

see pp. 78-83 above.

Manzanera, Teología, salvación y liberación, 185.
} 
To face the socioeconomic problems of the underdeveloped countries, Vatican II does not use the term "liberation," but "development." As a reaction to the conciliar developmental proposal and perceiving that what was needed to solve the problems in Latin America must go beyond development, Gutiérrez adopted the term "liberation." Still, the originality of Gutiérrez's theology is found in his tridimensional interpretation of liberation.: He sees in the process of liberation three dimensions working at the same time, though operating at separate levels. Despite their epistemological differences, he strives to demonstrate their interdependence in the process of salvation in Christ.- Thus, the utopian historical rationality, or second level, is the hinge that unifies the first level (i.e., the scientific rationality) with Christian Eaith, the third level. This tridimensional interpretation of liberation allows Gutiérrez to give various meanings to the same term. In general, liberation is seen as the overcoming of all forms of oppression, but the emphasis falls on the sociopolitical aspect.

As far as the Kingdom of God itself is concerned, Gutiérrez's multidimensional notion of liberation plays a key role in his understanding of the kingdom. On the one hand, it has helped him to avoid both the charge of

\footnotetext{
See pp. 81-83 above.

-See pp. 108-13 above.
} 
identifying the kingdom with any political system or program, and of reducing the kingdom to liberating actions. on the other, the way liberation is perceived affects how the kingdom is understood. These two concepts, liberation and kingdom, are so tied together that any modification of one will influence the other. Thus, our author may say that the proclamation of the message of the Kingdom of God means the end of injustice because it inspires a liberating approach in theological reflection.:

In short, Gutiérrez's notion of liberation is a nonnegotiable foundation of his theology. If this changed, it would affect not only his understanding of the kingdom of God, but his theology as a whole.

\section{Kingdom of God}

Most of Gutiérrez's understanding of the Kingdom paraliels that of Vatican II. For instance, both Gutiérrez and the conciliar documents regard the kingdom as primarily God's sovereignty as well as the domain over which He has that power. They also understand the Kingdom as being both present and future. In addition, they see the Kingdom as a divine gift that does not rule out human cooperation in its realization. Finally, both see the church as a sign or sacrament of the kingdom and concur that church and Kingdom are distinct.

\footnotetext{
"Entrevista de Ideele a Gustavo Gutiérrez," 21.
} 
Though Gutiérrez follows Vatican II's teaching about the Kingdom, this does not prevent our theologian from challenging the traditional Roman Catholic understanding in two fundamental ways. First, Gutiérrez objects to an essentially spiritual interpretation of the Kingdom claiming that it would be a misrepresentation of the meaning Jesus wanted to convey. He is convinced that Jesus' mission was not only a religious task but also a sociopolitical one. Christians, following the example of their master, should develop the societal structures that would provide better human conditions of life, particularly for the most vulnerable and marginalized of society. In doing so, they will hasten the ultimate realization of the Kingdom. As Gutiérrez sees it, there is a clear correlation between the realization of the Kingdom on earth and the elimination of any kind of exploitation, for in the Kingdom justice prevails over injustice and oppression is nonexistent.

Second, by linking the gospel to social justice, Gutiérrez intends to restore to the center of Christian theology the notion of the Kingdom as an earth-oriented society of Eraternal fellowship and justice. Since the Kingdom is understood as the utopia of absolute liberation that begins here on earth, it is seen as a worldtransforming power based on a new relationship with God, a relationship that eliminates injustice and misery from society. In other words, the kingdom is seen as having a 
sociopolitical impact on the present, and as involving all human efforts to transform the present reality.

The basic difference between Vatican II's and Gutiérrez's concept of the Xingdom of God arises from their hermeneutical presuppositions. While the council has overemphasized the afterlife and the spiritual character of the Kingdom, Gutiérrez, rejecting the spiritualization of the kingdom, has placed stress on its concrete realization in the here and now. This emphasis on the Kingdom as related to historical liberation led our author to consider the kingdom as the goal of history.

As far as human activity itself is concerned, the council not only gave serious consideration to human effort but also pointed out that when directed to improve the conditions of human life it "accords with God's will.": In this sense, each person might contribute to the unfolding of the plan of God for and in the world. Therefore, for the

"The Pastoral Constitution on the Church in the Modern World," art. 34 (Abbott, 232). The bishops at the Second Vatican Council referred to two aspects of reality: the griefs and the anxieties, as well as the joys and the hopes of humanity. The griefs and anxieties refer to the human tragedy that, while a small part of humanity enjoys the abundance of wealth, there is a reality of hunger and poverty that afflicts a huge proportion of the world's citizens (ibid., arts. 1, 4 [Abbott, 199-200, 2021). On the other hand, the joys and hopes point to a better future. Despite oppression and sufferings, there is hope in "a political, social, and economic order which will to an ever better extent serve man and help individuals as well as groups to affirm and develop the dignity proper to them" (ibid., art. 9 [Abbott, 206]). This hope, according to Gutiérrez, should motivate an aspiration for liberation. 
council, "the effort to establish a universal brotherhood is not a hopeless one.": However, the building of this new society is distinguished from the growth of the Kingdom of God. This distinction does not imply that they have little to do with each other. On the contrary, they are so closely interrelated that all the fruits of human efforts will be returned and purified by Christ at the parousia.'

The council's distinction between the construction of a new society and the coming of the Kingdom is regarded by Gutiérrez as inadequate because it overlooks the fact that charity unites these two processes." Due to his perception of an intrinsic relationship between the human struggle for liberation and the kingdom of God as a gift, Gutiérrez interprets Vatican II as saying that human activity is of supreme importance for the growth of the kingdom of God. In other words, the Kingdom, which belongs to the future, becomes present in the historical liberation achieved by human efforts. This implies that human beings can change history in the direction of the Kingdom of God. Precisely because Gutiérrez argues that it is only in the temporal sphere that one can open up to a future of complete

Ibid., art. 38 (Abbott, 236).

Ibid., art. 39 (Abbott, 237).

See above p. 146, n. 3 . 
fulfillment, he has been rightly accused of reducing the Kingdom to the construction of history. ${ }^{1}$

The way one understands the Kingdom of God has definite consequences for one's perception of the relationship between the creation of a more humane society and the growth of the kingdom of God. While Vatican II insists on a clear distinction between the two, Gutiérrez underscores their intimate connection. However, our author cautiously makes clear that this connection does not imply identity, for every achievement of justice and fraternity among human beings is incomplete and provisional. It is merely a step toward full communion, the ultimate realization of the Kingdom of God. This presupposition

See "Instruction on Certain Aspects of the 'Theology of Liberation,'" $\mathrm{x}, 3,4$. The Congregation for the Doctrine of the Faith notes that the identification of the kingdom and its growth with human liberation movement is in opposition to the teachings of Vatican II (ibid., $X, 4$ ). Cf. "Dogmatic Constitution on the Church," arts. 9-17 (Abbott, 24-37). In a document of the Episcopal Peruvian Conference issued in October 1984, the Peruvian bishops express their unanimous adherence to the first Instruction issued by the Congregation for the Doctrine of the Faith. Quoting Gaudium et spes (art. 39), they also refer to the distinction between the construction of a new society and the growth of the Kingdom of God. Contrary to Gutiérrez's view, the Peruvian bishops affirmed that unless this distinction were made, grace would be absorbed by nature, and the kingdom of God would be perceived as a result of human effort. On the other hand, they claim distinction without separation. They agree that Christians should be involved in the task for improving this world here and now, otherwise, they would be denying both the reality of the Christian faith as well as the saving power of God. Conferencia Episcopal Peruana, "Documento de la Conferencia Episcopal peruana sobre la teología de la liberación," Me II (March 1985): 139-40. 
allows him to keep in tension the understanding of the Kingdom as a divine gift and a human task. On the one hand, it is described as an eschatological gift, as the ultimate salvation freely given by God without mediation of any human effort. On the other, Christians are called to march toward the Kingdom while using their potential to transform history. The gratuitousness of the Kingdom does not exclude human cooperation; on the contrary, it expects the participation of all who accept the gift of the Kingdom. In other words, the coming of the Kingdom will be God's continuation of the work of human beings already in process in history. Pierre Bigo seems to have correctly summarized Gutiérrez's viewpoint by writing that

the fullness of life beyond death is this life fulfilled; that world is this world in its complete significance. The kingdom to come is all that will have been lived as communion here and now, to the extent to which it is already among us as sign.:

The concern for the social needs in Latin America has led Gutiérrez to develop a new insight into the meaning of the Kingdom of God. He insists that God's Kingdom should also be interpreted in the light of the liberating praxis and not only in the spiritual sense as advanced by vatican II. Thus, he continually highlights the historical realization of the kingdom. He does not want to wait for

'Pierre Bigo, The Church and Third World Revolution, trans. Jeanne Marie Lyons (Maryknoll, NY: Orbis, 1977), 143 (emphasis in the original). 
the future to see a renewed and just society: he wants it now, and he is working at it.

The Kingdom of God and the Church

As it has been noted in the preceding chapters, one may see in the documents of the second Vatican Council an attempt to moderate the Roman Catholic perspective that over the centuries saw a strong correlation between the church and the Kingdom. To reach a consensus, the council adopted an ambivalent approach on this point. While maintaining a distinction between Kingdom and church, their equation is not fully denied. They are so interrelated that they are considered identical.:

Gutiérrez, on his part, invariably denies any equation between the Kingdom and the church. The church as community signifies the kingdom, but it is not the Kingdom. They are not the same thing. Our author follows vatican II in its assertion that the church is a seed and a sign of the Kingdom. Such view led them to conclude that the church is an anticipation in history of the ultimate realization of the kingdom (i.e., it is a temporal precursor of what will be definitive and eternal). As Dulles remarks, the final coming of the kingdom of God will not be the destruction but the fulfillment of the church.:

\footnotetext{
See pp. 35-37, 151-57 above.

-Dulles, Models of the Church, 114.
} 
Like Vatican II, Gutiérrez sees the church as a pilgrim in its journey toward the promised land, the Kingdom of God. While marching to its final goal, the church has the responsibility to advance the kingdom in the world whether by witnessing or by proclamation. In this mission, all members of the church--clergy and laity--must be actively involved.: Before Vatican II, the laity did not play a prominent role in the mission of the church. They were silent worshipers who attended services in a language they did not understand. Their duty was basically Iimited to obedience and prayer. The council sees the laity as a powerful contact with the world and calls them to play an active role in making the world a better place by their testimonies. The openness of Vatican II to include the laity to serve the world and to extend the Kingdom encouraged Gutiérrez to call Christians to commit themselves to the transformation of the world, so that the resultant society might be a temporal representation of the final kingdom. Gutiérrez goes a step further than the council to affirm that if the church is to be faithful to its mission, it should not only verbally announce the kingdom but also actively promote its establishment on earth through the struggle for liberation.

See above pp. 119-25, 151-53.

-See above pp. 143-51. 
The Peruvian theologian also adopts the conciliar viewpoint that the church, in order to advance the Kingdom, must be vigilant to the signs of the times and interpret them in the light of the gospel. This approach is seen as necessary for the church to be able to respond to the questions human beings have concerning the present and future life and the interrelationship between the two.: Gutiérrez sees in this conciliar perspective an official permission for developing a new theological approach where the signs of the times are interpreted in the context of the Latin American situation and where the preferential option for the poor and oppressed plays a key role.

The fact that Gutiérrez adopted a view of the church similar to that of Vatican II does not necessarily mean that he agrees with the present attitude of the Roman Catholic Church. He criticizes its preferential option for the rich and ruling people. He calls the church to conversion and to participate actively in the liberation of the oppressed. To do this, the church should seek the transformation of the present socioeconomic structure and the elimination of

\footnotetext{
"The Pastoral Constitution on the Church in the Modern World," arts. 4-10 (Abbott, 201-9).

-Christian Duquoc is sympathetic with Gutiérrez's view of the church committed to the transformation of society. However, he is reluctant to make a link between a messianic utopia and Marxist activism. Christian Duquoc, Libération et progressisme: Un dialogue Théologique entre I'Amerique latine et I'Europe (Paris: Cerf, 1987). especially chaps. $1,5,7$.
} 
social classes. In other words, the church must be dissociated from the oppressor class in order to be able to cooperate in the creation of a new person in a more just and humane society. It is here that one finds the basic difference between Gutiérrez's and Vatican II's concept of the church as seed and sign of the Kingdom of God. Thus, while striving to keep his theology in harmony with the teaching of Vatican II, Gutiérrez often stretches its limits to make room for his liberation approach.

\section{conclusion}

The concept of the Kingdom of God has been of great significance throughout the history of Christendom because, among other things, it has shaped the Christian's conduct. The participants in the Second Vatican Council and Gutiérrez were not exceptions. By accepting that the Kingdom is manifested in mystery and in its initial stage in the church, the council abandoned the Constantinian and Tridentine triumphalistic view, where Kingdom and church were considered as synonymous. Gutiérrez, on the other hand, associated the kingdom of God with justice conceived as the satisfaction of the needs of the poor. Thus, his view on the kingdom led him to be actively involved in its construction because it is inseparable from the process of liberating praxis.

Ambivalence may be the appropriate word to explain the approach of Vatican II and Gutiérrez in dealing with the 
notion of the Kingdom; although in some cases ambiguity could describe better than any other term their claims on the issue. The ambivalent declarations found in the conciliar documents are the result of a compromise between progressive and conservative Roman Catholics. While the former demanded the renovation of the church, the latter were opposed to any significant change of Roman Catholic theology. Thus, though the council distinguished the church from the Kingdom, some statements refer to them as identical. On the other hand, the Peruvian theologian keeps in tension the conservative and progressive elements contained in the conciliar documents. Thus, he sees the kingdom as non-identical with any historical project and yet non-dissociated from human existence as social beings. In other words, the otherworldly dimension of the Kingdom does not deny its historical reality.

Gutiérrez's understanding of the Kingdom of God is firmly anchored in the conciliar documents. He acknowledges his dependence on the teachings of Vatican II and endeavors to be faithful to the official teaching of the church. Yet, because of his dialogue with progressive Roman Catholic and Protestant theologians as well as with Marxism, Gutiérrez often stretches the limits set by the council to the point that sometimes he gives the impression that he is walking in 
a different theological path. As Breckenridge: rightly notes, Gutiérrez has one foot firmly planted in the flow of the Roman Catholic mainstream, while the other one is planted outside of it--in dialogue with Marxism. One may conclude that while Gutiérrez's methodology differs from mainstream Roman Catholic teaching, the content of his theology follows more closely the progressive thought contained in the documents of Vatican II. Thus, by interpreting the kingdom from the perspective of the liberating praxis, Gutiérrez has the tendency to secularize it by making human beings responsible for its establishment on earth. Though he does not ignore the supernatural character of the Kingdom, his insistence in wedding the praxis of liberation to the kingdom makes it almost impossible for its realization apart from social and political structures.

Vatican officials strongly criticized his hermeneutical key because it modifies the presentation of the gospel in such a way that it departs from the faith of the Roman Catholic Church.: It is difficult for them to avoid the conclusion that Gutierrez's concept of the Kingdom resembles a Marxist thought, because his understanding of the Kingdom is centered in the praxis and directed to the

\footnotetext{
'Breckenridge, "The Ecclesiology of Gustavo Gutiérrez," 600-601.

- See "Instruction on Certain Aspects of Liberation Theology," VI, 9; $\mathrm{X}, 2 ; \mathrm{X}, 5-16$.
} 
transformation of the world. Although the Peruvian theologian admits the use of Marxist categories, he denies that his theology is Marxist as it has been labeled by conservative Roman Catholics. Instead he believes that the use of social sciences makes the Christian message relevant to modern society, because social sciences play a role similar to the one played by philosophy.: After all, Gutiérrez argues, what he is doing is just following the methodology of vatican II in its Pastoral Constitution on the Church in the Modern World.

According to vatican II, theology must have its starting point in the Scriptures and tradition, but Gutiérrez has challenged this conciliar teaching by having praxis instead. Vatican officials agree with Gutiérrez that

Segundo Galilea rejects the notion that liberation theologians, because of their use of the social sciences, are more sociologists than theologians. He suggests that to accuse them of being sociologists would be equivalent to accusing Thomas Aquinas of being a "philosophist." Segundo Galilea, Liberation Theology and the Vatican Document (Quezon City, Philippines: Claretian Publication, 1984), 15. Similarly. Ricardo Antoncich notes that if the writings of a theologian are labeled as Marxist because they challenge the unjust and social structures, then, most of the papal social encyclicals should also be labeled as Marxist because they share the same challenge (quoted in Brown, Theology in a New Key, 115).

- Gaudium et spes takes seriously the social sciences to provide the data for theological reflection. As Assmann admits, the methodology of this conciliar document became paradigmatic Eor Latin American theology. Hugo Assmann. Theology for a Nomad Church, trans. Paul Burns (Maryknoll, NY: Orbis, 1976), 63. Gutiérrez ("Church of the Poor," 14) notes that social sciences were also used at the meetings of Latin American bishops at Medelín and Puebla. 
Christians need to understand the social reality they live in, so that they can have a proper attitude toward it. Likewise, they agree that Christians need to take their social responsibility more seriously and participate in the changes required for a better society. However, they strongly argue that this should be done having the Scriptures and tradition, not social sciences, as the foundation of their action, proclamation, and teaching.:

It is here that conservative Roman Catholics find the Achilles heel of Gutiérrez's theology and of his understanding of the kingdom. His methodology subordinates the Word of God to the socioeconomic and political context to the point that it seems to aim at the redemption of the social order, not of the individual believer. Thus, the Kingdom seems to be more a projection of the aspiration of

:Protestant theologians have done similar observations. Social sciences should not take the place of the scriptures as the basis for theology. Carl Henry discusses this well: "Instead of first focusing on Christ and the Bible as the revelational center of human history and destiny, and by that light illuminating the cultural context, liberation theologians like Gustavo Gutiérrez make existing social and political conditions the necessary lens for viewing and interpreting scriptural data. Man's Eactual historical condition is considered the necessary starting point; from the outset faith gains a political dimension and reference. What specially characterizes liberation theologians is their insistence that theological reflection must begin with the historical situation rather than with the biblical revelation, and thus becomes directed toward a prestipulated social reconstruction." Carl F. H. Henry, "Liberation Theology and the Scriptures," in Liberation Theology, ed. Ronald H. Nash (Milford, MI: Nott Media, 1984), 196 . 
the Latin American poor than a reflection of what the Scriptures say about the Kingdom.

To see the human efforts for the transformation of the world as directly linked to the growth of the kingdom is to overiook the presence of $\sin$ and its consequences. It is true that Christians should strive to improve the society in which they live, but should this be regarded as a historical realization of the Kingdom because God's Kingdom is manifested even in adverse historical circumstances? At the present, the presence of the kingdom is revealed both in the deliverance of human beings from the power and penalty of sin and in their inner transformation. Yet, the future and ultimate manifestation of the kingdom will be a reality in the new earth at the end of the millennium as promised in Rev 21.

Gutiérrez makes several contributions to Latin American Catholic theology. First, he insists in making Catholic theology not only an intellectual and academic exercise but also part of Christians' everyday life. He is convinced that theology is both a rational experience and a liberating commitment. Next, having a profound concern for the poor and oppressed, Gutiérrez's theology is concerned with their liberation. Thus, he proposes an understanding of the Kingdom roored in the praxis of Iiberation that must be understood from the perspective of the poor. Third, he contributes to giving a visible meaning to the notion of the 
Kingdom, suggesting that it is a world-transforming power that embraces all dimensions of human existence. Gutiérrez challenges other Christian denominations to evaluate their social ministry and to correct it if necessary. Finally, his liberation approach from which all biblical themes should be understood and explained is also seen as a contribution to his tradition. In fact, the "Instruction on Certain Aspects of the Theology of Liberation" regards the expression "theology of liberation" as a valid term, because "it designates a theological reflection centered on the biblical theme of liberation and freedom, and on the urgency of its practical realization.": However, the Instruction makes it clear that any liberation theology should be in harmony with the teaching authority of the church.

In particular, Gutiérrez's notion of the Kingdom as a world-transforming power has the purpose of allowing Latin American Catholics to be militant in the political arena while not denying their faith or being indifferent to it. Thus, he seeks to answer the question of how Christians should behave politically in Latin America, because, for him, to follow Jesus involves a commitment to defend the oppressed and to transform unjust social structures.

Gutiérrez's new approach to theology may be considered both one of his main contributions and at the

"Instruction on Certain Aspects of the 'Theology of Liberation, " III, 4. 
same time one of his main weaknesses, because it ignores the authority of the scriptures. Although social sciences can be a helpful tool for understanding the oppressive social conditions in Latin America, they can never be the foundation of Christian faith and practice. As the divinely inspired and normative source of the truth, Scripture is the supreme authority and the basis for any true theological reflection.

One still wonders why Gutiérrez does not pay more attention to the notion of sin as the cause of all the evils suffered by all men, including the poor. Although Gutiérrez recognizes the problem of personal sin as well as social sin, one gets the impression that he tends to overlook personal sin by overemphasizing social sin as manifested in oppressive structures. Thus he Eails to acknowledge that the root of Latin American problems is to be found within human beings themselves. From their very birth, men and women, regardless their sociopolitical condition, have a congenital inclination to evil.

The recognition of the fact that there is certain value in the obligation of Christians to work for the establishment of a just society poses new questions which require careful consideration. If sociopolitical just structures are necessary for the arrival of the Kingdom, can the kingdom be genuinely present apart from these structures? Is the realization of the kingdom bound to 
subversive praxis which leads to change in the social order in favor of the poor and oppressed?

There are serious problems in the manner Gutiérrez uses the praxis as the locus for theological reflection. If truth is neither existent nor verified apart from praxis, then a theological interpretation of history will be regarded true or mistaken according to its ability to motivate praxis. How can Christians avoid the risk of reducing Christian faith to a kind of revolutionary political action? Besides, are human beings in their sinful condition able to build a less sinful society? Finally, there is the question of the relationship between the church and the Kingdom. Serious consideration should be given to whether or not the church will merge with the kingdom of God at the end. 


\section{BIBLIOGRAPHY}

\section{Gustavo Gutiérrez Merino}

"Buscar el Reino." Páginas 79 (September 1986): 2, 51.

"Caminando con el pueblo." Introduction to la práctica de Jesús, by Hugo Echegaray, 5-26. 3d ed. Lima: CEP, 1989. This article was originally published in Páginas 4 (1979): $1-11$.

"Church of the Poor." In Born of the Poor, ed. Edward L. Cleary, 9-25. Notre Dame, IN: University of Notre Dame Press, 1990.

"Contestation in Latin America." In Contestation in the Church, ed. Teodoro Jiménez Urresti, 40-52. New York: Herder and Herder, 1971.

La evangelización y opción por los pobres. Buenos Aires: Ediciones Paulinas, 1987.

"Faith as Freedom: Solidarity with the Alienated and Confidence in the Future." Horizons 2 (1975): 2560 .

"Freedom and Salvation: A Political Problem." In Liberation and Change, ed. Ronald H. Stone, 3-94. Atlanta: John Knox Press, 1977.

The God of Life. Translated by Matthew J. O'Connell. Maryknoll, NY: Orbis, 1991. Spanish edition, El Dios de la vida. Lima, Perú: CEP, 1989.

"The Hope of Liberation." Worldview 17 (June 1974): $35-37$.

"Iglesia y apostolado universitario." Lecture delivered to the Unión Nacional de Estudiantes Católicos on $26 \mathrm{July} 1960$. Documents Collection. Lima: Centro Bartolomé de Las Casas, 1960. 
"La Iglesia de los pobres: Perspectiva bíblica." Pastoral Andina 30 (April 1980): 13-32.

"The Irruption of the Poor in Latin America and the Christian Communities of the Common People." In The Challenge of Basic Christian Communities, ed. Sergio Torres and John Eagleson, trans. John Drury, 107-23. Maryknoll, NY: Orbis, 1981.

Las Casas: In Search of the Poor of Jesus Christ. Translated by Robert R. Barr. Maryknoll, NY: Orbis, 1993. Spanish edition, En busca de 105 pobres de Jesucristo: el pensamiento de Bartolomé de Las Casas. Lima, Perú: CEP, 1992.

"Liberation. Theology and Proclamation." In The Mystical and Political Dimension of the Christian Faith, ed. Claude Geffré and Gustavo Gutiérrez, 57-77. New York: Herder and Herder, 1974.

"Liberation Movements and Theology." In Jesus Christ and Human Freedom, ed. Edward Schillebeeckx and Bas Van Iersel, 135-146. New York: Herder and Herder, 1974.

"Liberation Praxis and Christian Faith." In Frontiers of Theology in Latin America, ed. Rosino Gibellini, trans. John Drury, 1-33. Maryknoll, NY: Orbis, 1979.

Líneas pastorales de la Iglesia en América Latina. 5th ed. Lima: CEP, 1979.

"Marxismo-Cristianismo." Edited by Centro Critico Universitario (CECRUN). México D.F., México: CECRUN, 1971.

"A Path of Reflection, an Intent to speak of God." In Liberation Thinking: An Evangelical Assessment, ed. W. Dayton Roberts, 41-47. Monrovia, CA: MARC Publications, 1987.

"The Poor in the Church." In The Poor and the Church, ed. Norbert Greinacher and Alois Müller, 11-16.

New York: Seabury Press, 1977. 
The Power of the Poor in History. Translated by Robert R. Barr. Maryknoll, NY: Orbis, 1983. Spanish edition, La fuerza histórica de los pobres. Lima, Perú: CEP, 1979.

"The Praxis of Liberation and the Christian Faith." Lumen Vitae $29(1974): 373-400$.

"Reflections from a Latin American Perspective: Finding Our Way to Talk about God." In Irruption of the Third World: Challenge to Theology, ed. Virginia Fabella and Sergio Torres, 222-34. Maryknoll, NY: Orbis, 1981 .

"El Reino está cerca." Signos 12 (January 1991): 2.

"Speaking about God." In Different Theologies, Common Responsibility: Babel or Pentecost?, ed. Claude Geffré and Gustavo Gutiérrez, and V. Elizondo, 27 31. Edinburgh: T. \& T. Clark, 1984.

"Statement by Gustavo Gutiérrez." In Theology in the Americas, ed. Sergio Torres and John Eagleson, 309-13. Maryknoll, NY: Orbis, 1976.

"Terrorism, Liberation and Sexuality." The Witness (April 1977) : 10-11

"Theology and Spirituality in a Latin American Context." Harvard Divinity Bulletin 14 (JuneAugust 1984): 4-5.

A Theology of Iiberation: History, Politics and Salvation. Translated and edited by sister Caridad Inda and John Eagleson. Maryknoll, NY: Orbis, 1973. Spanish edition, Teología de la liberación. Lima, Perú: CEP, 1971.

A Theology of Liberation: History, Politics and Salvation. Revised edition with a New Introduction. Translated and edited by Sister Caridad Inda and John Eagleson. Maryknoll, NY: Orbis, 1988 . 
The Truth Shall Make You Free: Confrontations. Translated by Matthew J. O'Connell. Maryknoll, NY: Orbis Books, 1990. Spanish edition, La verdad Ios hará libres. Lima, Perú: CEP, 1986.

"Two Theological Perspectives: Liberation Theology and Progressivist Theology." In The Emergent Gospel. ed. Sergio Torres and Virginia Fabella, 227-55. Maryknoll, NY: Orbis, 1976.

"Vaticano II y la Iglesia latinoamericana." Páginas 70 (August 1985): 1-12.

We Drink from Our Own Wells. Translated by Matthew $\mathrm{J}$. O'Connell. Maryknoll, NY: Orbis Books, 1984. Spanish edition, Beber en su propio pozo: En el itinerario espiritual de un pueblo. Lima, Perú: CEP, 1983.

Gutiérrez, Gustavo, and Richard Schaull. Liberation and Change. Atlanta: John Knox Press, 1977.

\section{Other sources}

Abalos, David. "The Medellin Conference." Cross Currents 19 (1969): 113-32.

Abbott, Walter M., ed. The Documents of Vatican II. New York: America Press, 1966.

Adam, Karl. The Spirit of Catholicism. Rev. ed. Translated by Dom Justin McCann. New York: Macmilian, 1954.

Alberigo, Giuseppe. "The Council of Trent." In Catholicism in Eariy Modern History, ed. John O'Malley, 211-26. Ann Arbor, MI: Edwards Brothers, 1988.

. "1965-1995: Thirty Years After Vatican II." In History of Vatican II, ed. Giuseppe Alberigo and Joseph A. Komonchak, $1: x i-x V$. Maryknoll, NY: Orbis, 1995.

Alington, C. A. The Kingdom of God. London: Centenary Press, 1940 . 
Alzog, John. History of the Church. 3 vols. Translated by F. J. Pabisch and Thomas S. Byrne. New York: Benziger Brothers, 1912.

Ambrose of the Christian Faith. The Nicene and PostNicene Fathers, 2d Series. 10:201-314.

Expositio in Psalmum cxviii. Patrologiae Cursus Completus, Series Latina. 15:1261-1604.

Aquinas, Thomas. Super Evangelium S. Matthaei: Lectura. Edited by Raffaele Cai. Turin: Marietti, 1951.

- Summa Contra Gentiles. 5 vols. Trans., intro. and notes by Anton G. Pegis et al. Garden City, NY: Doubleday, 1955-57.

Araya, Victorio. God of the Poor. Translated by Robert R. Barr. Maryknoll, NY: Orbis, 1987.

Arrupe, Pedro. "Marxist Analysis by Christians." Origins 10 (April 16, 1981): 690-93.

Assmann, Hugo. Opresión-liberación: desafío a los cristianos. Montevideo, Uruguay: Tierra Nueva, 1971 .

"Statement by Hugo Assmann." In Theology in the Americas, ed. Sergio Torres and John Eagleson, 299-303. Maryknoll, NY: Orbis, 1976.

Theology for a Nomad Church. Translated by Paul Burns. Maryknoll, NY: Orbis, 1976.

Athanasius Discurse II Against the Arians. The Nicene and Post-Nicene Fathers, 2d Series. 4:306-447.

. De Synodis. The Nicene and Post-Nicene Fathers, 2d series. 4:451-80. De Incarnatione Dei Verbi, et Contra
Arianos. Patrologiae Cursus Completus, Series
Graeca. $26: 985-1028$.

Attwater, Donald, comp. "The Kingdom of God." A Catholic Dictionary. New York: Macmillan, 1958. 
Augustine The City of God. The Nicene and Post-Nicene Fathers. 2:1-511.

Expositions on the Psalms. The Nicene and Post-Nicene Fathers. $8: 1-683$.

On Baptism, Against the Donatists. The Nicene and Post-Nicene Fathers. 4:411-514.

Azzi, Riolando. "La Teología en el Brasil: Consideraciones Históricas." In Materiales para una historia de la teología en América Latina, ed. CEHILA, 41-79. San José, Costa Rica: Departamento Ecuménico de Investigaciones, 1980.

Bacik, James J. Contemporary Theologians. New York: Triumph Books, 1989.

Barbieri, Sante Uberto. The Land of Eldorado. New York: Friendship Press, 1961.

Baum, Gregory. "Faith and Liberation: Development since Vatican II." In Vatican II: Open Questions and New Horizons, ed. Gerald M. Fagin, 75-104. Wilmington, DE: Michael Glazier, 1984.

"Gutiérrez and the Catholic Tradition." The Ecumenist 21 (September-October 1983): 81-84.

Benko, Stephen. "The Kingdom of God in the Documents of Vatican II." In Gottesreich und Menschenreich, ed. Ernst Staehelin, 571-83. Basel: Helbing \& Lichtenhahn, 1969.

Benz, Ernst. Evolution and Christian Hope. Translated by Heinz G. Frank. Garden City, NY: Doubleday, 1966 .

Beskow, Per. Rex Gloriae. The Kingship of Christ in the Early Church. Translated by Eric Sharpe. Stockholm: Almquist \& Wiksell, 1962.

"Bibliographical Essays." In The Cambridge History of Latin America, ed. Leslie Bethell, 1:557-623. Cambridge: Cambridge University Press, 1984. 
Bigo, Pierre. The Church and Third World Revolution. Translated by Jeanne Marie Lyons. Maryknoll, NY: Orbis, 1977.

Blue, John Ronald. "Origins of Gustavo Gutierrez' 'A Theology of Liberation." " Ph.D. dissertation, The University of Texas at Arlington, 1989.

Boff, Clodovis. Theology and Praxis. Translated by Robert R. Barr. Maryknoll, NY: Orbis Books, 1987.

Boff, Leonardo. Faith on the Edge: Religion and Marginalized Existence. Translated by Robert R. Barr. New York: Harper \& Row, 1989.

"Salvation in Jesus Christ and the Process of Liberation." Concilium 6 (June 1974): 78-91.

Boff, Leonardo, and Clodovis Boff. Iiberation Theology: From Confrontation to Dialogue. Translated by Robert R. Barr. San Francisco: Harper \& Row, 1986.

Salvation and Liberation. Translated by Robert R. Barr. Maryknoll, NY: Orbis Books, 1984.

Bokenkotter, Thomas. A Concise History of the Catholic Church. Rev. and enl. ed. New York: Doubleday, 1990 . 1986

Essential Catholicism. New York: Doubleday,

Braaten, Carl E. "Praxis: The Trojan Horse of Liberation Theology." Dialog 23 (1984): 276-80.

Brackley, Dean J. "Salvation and the Social Good in the Thought of Jacques Maritain and Gustavo Gutierrez." Ph.D. dissertation, University of Chicago, 1980.

Brauer, Jerald C. "Kingdom of God." In A Handbook of Christian Theology, ed. Marvin Halverson and Arthur A. Cohen, 197-201. Cleveland, OH: World Publishing Co., 1958.

Breckenridge, Robert L. "The Ecclesiology of Gustavo Gutiérrez Merino: Contours, Sources and Impact." Ph.D. dissertation, Southern Methodist University, 1993. 
Bright, John. The Kingaiom of God. Nashville, TN: Abingdon, 1953.

Brito Olivares, José. "La teología de la Liberación en Gustavo Gutiérrez." Th.D. Thesis, Université Catholique de Louvain, 1973.

Brown, Robert McAfee. Gustavo Gutiérrez. Atlanta: John knox Press, 1980.

Theology in a New Key. Philadelphia: Westminster, 1978.

Bultmann, Rudolf. Jesus and the Word. New York: Scribner, 1958.

Burkholder, Anne Leighton. "Dependence Thought in Latin American Liberation Theology: A study in the Relationship Between the Social Sciences and Theology." Ph.D. dissertation, Emory University. 1992 .

Burns, E. Bradford. Latin America: A Concise Interpretative History. Englewood Cliffs, NJ: Prentice-Hall, 1972.

Butler, Christopher. The Theology of Vatican II. London: Darton, Longman \& Todd, 1967.

Calvin, John. The Institures of the Christian Religion. The Library of Christian Classics, vol. 21. Edited by John T. McNeill, translated by Ford Lewis Battles. Philadelphia, PA: Westminster, 1960 .

Candelaria, Michael R. Popular Religion and Liberation. Albany, NY: State University of New York Press, 1990.

Candish, James $S$. The Kingdom of God. Edinburgh: $T$. \& T. Clark, 1884 .

Cantor, Norman F. The Meaning of the Middle Ages. Boston: Allyn and Bacon, 1973.

Carlen, Claudia, comp. The Papal Encyclicals. 5 vols. Wilmington, NC: MCGrath Pub. Co., 1981-90. 
Carmody, Denise L., and John Carmody. Roman Catholicism: An Introduction. New York: Macmillan, 1990.

Carr, Anne. "Theology and Experience in the Thought of Karl Rahner." Journal of Religion 53 (1973): 35976 .

Catechism of the Catholic Church. Chicago: Loyola University Press, 1994.

Catechism of the Council of Trent. Translated by John A. McHugh and Charles CaIlan. Rockford, IL: Tan, 1982 .

Catholic Church, Consejo Episcopal Latinoamericano. The Church in the Present-Day Transformation of Latin America in the Light of the Council: Position Papers. washington, DC: U.S.C.C., 1973.

Chenu, Marie-Dominique. Faith and Theology.

Translated by Denis Hickey. New York: Macmillan, 1968 .

Is Theology a Science? Translated by A. H. N. Green-Armytage. London: Burns \& Oates, 1959. - Pour une théologie du travail. Paris: Editions du Seuil, 1955.

Chilton, Bruce. "Introduction." In The Kingdom of God, ed. Bruce Chilton, 1-26. Philadelphia: Fortress, 1984 .

Codina, Victor. "Tres modelos de ecclesiología." Estudios Eciesiásticos 58 (1983): 55-82.

Cohn, Norman. The Pursuit of the Millenium. Rev. and enl. ed. New York: Oxford University Press, 1970.

Collier, Jonn Jr., and Aníbal Buitrón. The Awakening Valley. Chicago: University of Chicago Press, 1949 .

Comblin, José. "The Church in Latin America after Vatican II." Latin American Documentation 7 (Jan.-Feb. 1977): 1-18. 
The Church and the National Security State. Maryknoll, NY: Orbis, 1979.

Comisión Episcopal de Acción Social. Between Honesty and Hope. Translated by John Drury. Maryknoll, NY: Maryknoll Publications, 1970.

Conferencia Episcopal Peruana. "Documento de la Conferencia Episcopal Peruana sobre la teología de la liberación." Medelín 11 (March 1985) : 130-44.

Congar, Yves. Christians Active in the world.

Translated by $F$. Hepburne-Scott. New York: Herder and Herder, 1968.

\section{Dialogue between Christians. Translated by} Philip Loretz. Westminster, MD: Newman Press, 1966 .

- Divided Christendom: A Catholic study of the Problem of Reunion. Translated by M. A. Bousfield. London: Centenary Press, 1939.

L'Église: De Saint Augustin à I'époque moderne. Paris: Éditions du Cerf, 1970.

Lay People in the Church. Rev. ed. Translated by Donald Attwater. Westminster, MD: Newman Press, 1967.

- Une peuple messianique. Paris: Éditions du Cerf, 1975.

Congregation for the Doctrine of the Faith. "Instruction on Certain Aspects of the 'Theology of Liberation." Origins 14 (September 13, 1984): 193-204.

Congregation for the Doctrine of the Faith. "Instruction on Christian Freedom and Liberation." Origins 15 (April 17, 1986): 713-28.

Cook, Michael L. "Jesus from the other side of History: Christology in Latin America." Theological Studies 44 (1983): 258-87. 
Costas, Orlando E. The Church and Its Mission:

Shattering Critique from the Third World.

Wheaton, IL: Tyndale House, 1974.

. Theology of the Crossroads in Contemporary

Latin America. Amsterdam: Rodopi, 1976.

Cotto-Serrano, Raul L. "The Significance of Politics in the Liberation Theology of Juan Luis Segundo and Gustavo Gutierrez." Ph.D. dissertation, University of Massachusetts, 1990.

Cowden-Guido, Richard. John Paul II and the Battle for Vatican II. Manassas, VA: Trinity Communications, 1986 .

Cranz, Edward F. "Kingdom and Polity in Eusebius of Caesarea." Harvard Theological Review 45 (1952): $47-66$.

Croato, Severino. "The Gods of Oppression." In The Idols of Death and the God of Life: A Theology, ed. Pablo Richard et al., 26-45. Maryknoll, NY: Orbis, 1983.

Crosby, Daniel E. "A Critique of the Pneumatological Paradigm in the Theologies of James D. G. Dunn and Gustavo Gutierrez: A Question of Eschatology." Ph.D. dissertation, Southwestern Baptist Theological Seminary, 1990.

Cullmann, Oscar. Christ and Time: The Primitive Christian Conception of Time and History. Rev. ed. Philadelphia: Westminster Press, 1964. - Jesus and the Revolutionaries. Translated by Gareth Putnam. New York: Harper \& Row, 1970. The State in the New Testament. New York: Scribner, 1956.

Davies, J. G. The Early Christian Church. New York: Holt, Rinehart and Winston, 1965.

de Chardin, Teilhard. The Divine Milieu. Translated by Bernard Wall. New York: Harper \& Brothers, 1960 . 
de Lubac, Henry. Catholicism. Translated by Lancelot C. Sheppard. New York: Mentor-Omega Books, 1964.

Deansly, Margaret. A History of the Medieval Church 590-1500. London: Methen, 1960.

Delumeau, Jean. Catholicism between Luther and Voltaire. Translated by Jeremy Moiser. London: Burns \& Oates, 1977.

A Dictionary of the Popes. Compiled by Donald Attwater. London: Burns Oates \& Washbourne, 1939.

Dixon, David C. "A Critical Analysis of Liberationist Christology in the Writings of Gustavo Gutierrez, Leonardo Boff, and Jon Sobrino." Ph.D. dissertation, Southwestern Baptist Theological Seminary, 1988.

Dodd, Charles H. The Parables of the Kingdom. London: Nisbet \& Co.. 1936.

Dolan, John P. Catholicism: A Historical Survey. Woodbury, NY: Barron's Educational Series, 1968.

Dorr, Donal. Option for the Poor. Maryknoll, NY: Orbis, 1983.

Duling, Dennis $c$. "The Kingdom of God in the Teaching of Jesus." word \& World 2 (1982): 117-26.

Dulles, Avery. "The Catholic Ecclesiology since Vatican II." In Synod 1985: An Evaluation, ed. Giusseppe Alberigo and James Provost, 3-13. Edinburgh: T. \& T. Clark, 1986.

"The Church in the Catechism." In The Universal Catechism Reader, ed. Thomas J. Reese, 84-92. San Francisco: Harper, 1990.

The Dimensions of the Church. Westminster, MD: Newman Press, 1967.

- Modeis of the Church. New York: Doubleday, 1974.

Dupertuis, Atilio R. Liberation Theology: A Study in Its Soteriology. Berrien Springs, MI: Andrews University Press, 1982. 
Duquoc, Christian. Libération et progressisme: Un dialogue Théologique entre I'Amerique latine et I'Europe. Paris: Éditions du Cerf, 1987.

Durand, Ricardo. Observaciones a Teología de la Liberación. Callao, Perú: [Obispado del Callao]. 1985 .

La utopía de la liberación. Callao, Perr: Arzobispado del Callao, 1988.

Dussel, Enrique. A History of the Church in Latin America. Translated and revised by Alan Neely. Grand Rapids, MI: Eerdmans, 1981.

History and Theology of Liberation.

Translated by John Drury. Maryknoll, NY: Orbis, 1976.

. "The Kingdom of God and the Poor." International Review of Mission 69 (1979): 115-37.

"The Political and Ecclesial Context of Liberation Theology in Latin America." In The Emergent Gospel, ed. Sergio Torres and Virginia Fabella, 175-92. Maryknol1, NY: Orbis, 1976.

Echegaray, Hugo. La práctica de Jesús. 3d ed. Lima: CEP, 1989.

Edgar, Samuel. The Variations of Popery. New York: $S$. W. Benedict, 1850 .

Editorial. Wall Street Journal, March 30, 1967, 14.

Elizondo, Virgilio. "The Pope's Opening Address: Introduction and Commentary." In Puebla and Beyond, ed. John Eagleson and Philip Scharper, 4755. Maryknoll, NY: Orbis, 1979.

"Entrevista de Ideele a Gustavo Gutiérrez." Ideele 58 (November 1993): 21 .

Eusebius The Oration of Eusebius Pamphilus. The Nicene and Post-Nicene Fathers, 2d series. 1: 581-610. 
Evans, Robert. One and Holy: The Church in Latin Patristic Thought. London: SPCK, 1972.

Fairweather, Eugene R. "The Church." In The Second Vatican Council: Studies by Eight Anglican observers, ed. Bernard Pawley, 54-84. London: Oxford University Press, 1967.

Falconi, Carlo. The Popes in the Twentieth Century. Translated by Muriel Grindrod. Boston: Little, Brown and Co., 1967.

Ferm, Dean W. "South American Liberation Theology." Religion in Life 48 (1979): 474-91.

- Third World Theologies: An Introductory Survey. Maryknoll, NY: Orbis, 1986.

Fierro, Alfredo. The Militant Gospel. Translated by John Drury. London: SCM Press, 1977.

Figgis, John N. The Political Aspects of $S$. Augustine's 'City of God.' London: Longmans, Green, and Co., 1921.

Fiorenza, Francis P. "Latin American Liberation Theology." Interpretation 28 (1974): 441-57.

Freire, Paulo. "Education as Cultural Action: An Introduction." In Conscientization for Liberation, ed. Louis M. Colonnese, 109-22. Washington, DC: Division for Latin America--USCC, 1971.

. Pedagogy of the Oppressed. Translated by Myra Bergman Ramos. New York: Continuum, 1981.

Fuellenbach, John. "Kingdom of God." Dictionary of Fundamental Theology. Edited by René Latourelle. New York: Crossroad, 1994.

- The Kingdom of God: The Message of Jesus Today. Maryknoll, NY: Orbis, 1995.
Galilea, Segundo.
Politics and
"Liberation as an Encounter with 1974) : $19-33$. 
Liberation Theology and the Vatican Document. Quezon City, Pilippines: Claretian Publication, 1984.

"The Theology of Liberation." Lumen Vitae $33(1978): 331-53$.

Geffré, Claude. "A Prophetic Theology." Concilium 6 (June 1974): 7-16.

Gibelini, Rosino, ed. Frontiers of Theology in Latin America. Translated by John Drury. Maryknoll, NY: Orbis, 1979.

Gilson, Etienne. The Christian Philosophy of Saint Augustine. Translated by L. E. M. Lynch. New York: Random House, 1960.

González, Carlos Ignacio. "La teología de la liberación a la luz del magisterio de Juan Pablo II en América Latina." Gregorianum 67 (1986): 546 .

González, Justo. A History of Christian Thought. 3 vols. Nashville, TN: Abingdon, 1970-75.

Gregory the Great Homiliarum in Evangelia. Patrologiae Cursus Completus, series Latina, 76:1236-37.

Gremillion, Joseph, ed. The Gospel of Peace and Justice. Maryknoll, NY: Orbis, 1976.

\footnotetext{
"Science's Magnification--and Socialization --of Economic Power." In The Gospel of Peace and Justice, ed. Joseph Gremillion, 23-37. Maryknoll, NY: Orbis, 1976 .

Greenleaf, Richard E. The Roman Catholic Church in Colonial Latin America. New York: Alfred A. Knopf, 1971.

Gritsch, Eric w. "The Lordship of Christ in Christian History." In Christian Hope and the Lordship of Christ, ed. Martin J. Heinecken, 33-46. Minneapolis, MN: Augsburg, 1969.
} 
Groh, John E. "The Kingdom of God in the History of Christianity: A Bibliographical Survey." Church History $43(1974)$ : 257-67.

Gudorf, Christine E. Catholic Social Teaching. Lanham, MD: University Press of America, 1980.

"Gustavo Gutierrez: Liberation Theologian." One World $8(1975): 13-14$.

Haight, Roger D. An Alternative Vision: An Interpretation of Liberation Theology. Mahwah, NJ: Paulist Press, 1985.

"Mission: the Symbol for Understanding the Church Today." Theological Studies 37 (1976): $620-49$.

Hamilton, Kenneth. "Theology: Lessons Positive and Negative." In Evangelicals and Liberation, ed. Carl E. Armerding, 120-27. Grand Rapids, MI: Baker, 1977 .

Hanke, Lewis, ed. History of Latin American Civilization. 2 vols. Boston: Little, Brown and Co., 1967 .

Haring, Clarence $\mathrm{H}$. The Spanish Empire in America. New York: Oxford University Press, 1947.

Harkness, Georgia. Understanding the Kingdom of God. Nashville, TN: Abingdon, 1974.

The HarperCollins Encyclopedia of Catholicism. 1995. S.v. "Daniélou, Jean."

Haughey, John C. "Church and Kingdom: Ecclesiology in the Light of Eschatology." Theological Studies 29 $(1968)$ : 72-86.

Hayes, Zachary. Visions of a Future: A Study on Christian Eschatology. Wilmington, DE: Michael Glazier, 1989.

Hebblethwaite, Brian. The Christian Hope. Grand Rapids, MI: Eerdmans, 1984. 
Hebblethwaite, Peter. Theology of the Church. Notre Dame, IN: Fides, 1969.

Hefner, Philip. "Theology Engagée: Liberational, political, Critical." Diaiog 13 (1974): 188-94.

Hegy, Pierre. Review of A Theology of Liberation, by G. Gutiérrez. Journal for the Scientific study of Religion 13 (1974): 243-44.

Hellwig, Monika K. "Eschatology." In Systematic Theology. Roman Catholic Perspectives, ed. Francis Schüssler Fiorenza and John P. Galvin, 2:349-72. Minneapolis: Fortress, 1991.

Hengel, Martin. Was Jesus a Revolutionist? Translated by William Klassen. Philadelphia: Fortress, 1971.

Hennelly, Alfred T. "Apprentices in Freedom: Theology since Medelín." America 138 (May 27, 1978) : 41821 .

. "Courage with Primitive Weapons." Cross Currents 28 (1978): 8-19.

"Theological Method: The Southern Exposure." Theological Studies 38 (1977): 709-35.

Henrici, Peter. "The Council's Development to Madurity: An Experience of Pre-Conciliar Theology." Communio International Catholic Review 17 (I990): 504-22.

Henry, Carl F. H. "Liberation Theology and the Scriptures." In Liberation Theology, ed. Ronald H. Nash, 189-202. Milford, MI: Nott Media, 1984.

Herr, William A. This our Church. Chicago, IL: Thomas More Press, 1986.

Hilary on the Trinity. The Nicene and Post-Nicene Fathers, 2d Series. 9:40-233.

Hill, Bennett D., ed. Church and state in the Middle Ages. New York: John Wiley \& Sons, 1970.

Hollis, Christopher. The Achievements of Vatican II. New York: Hawthorn Books, 1967. 
Hünermann, Peter. "Reign of God." Encyclopedia of Theology: The Concise Sacramentum Mundi. Edited by Karl Rahner. New York: Crossroad, 1991.

Hynes, Mary J. "Gustavo Gutierrez's Concepts and Images of God." Ph.D. dissertation, Saint Louis University, 1991.

Illanes, José Luis. "Teología de la liberación: análisis de su método." Scripta Theologica 17 $(1985)$ : $743-88$.

Jay, Eric G. The Church. Atlanta: John Knox Press, 1980.

Jedin, Hubert. History of the council of Trent. 3 vols. Translated by Dom E. Graf. London: Thomas Nelson, 1957-61.

Jeremias, Joachim. New Testament Theology. Translated by John Bowden. New York: Scribner, 1971. - The Parables of Jesus. Translated by S. H. Hooke. London: SCM Press, 1954.

John XXIII. "Pope John's Opening Speech to the Council." In The Documents of Vatican II, ed. Walter Abbott, 710-19. New York: America Press, 1966.

John Paul II, "Redemptoris Missio." In The Encyclicals of John Paul II, ed. J. Michael Miller. 494-570.

Huntington, IN: Our Sunday Visitor, 1996.

"Opening Address at the Puebla Conference." In Evangelization at Present and in the Future of Latin America: Conclusions, ed. National Conference of Catholic Bishops, 1-15. Washington, DC: Committee for the Church in Latin America, 1979.

Journet, Charles. L'Église du Verbe Incarné. 2 vols. Paris: Descleé de Brouwer, 1962.

"Justice in the world." In The Gospel of Peace and Justice, ed. Joseph Gremillion, 513-29. Maryknoll, NY: Orbis, 1976 .

Kant, Immanuel. Critigue of Practical Reason. Translated and introduction by Lewis White Beck. New York: Bobbs-Merrill, 1956. 
Religion Within the Limits of Reason Alone. Translated and introduction by Theodore $M$. Greene and Hoyt $\mathrm{H}$. Hudson. New York: Harper \& Brothers, 1960 .

Kelly, John N. D. The Early Christian Doctrines. Rev. ed. New York: Harper \& Row, 1978.

. "St. Gregory I." The Oxford Dictionary of

Popes. Oxford: Oxford University Press, 1986.

Kendrick, Peter Wright. "Christian Freedom and

Liberation: A Biblical and Theological Critique of the Concept of Salvation in the Theology of Gustavo Gutierrez." Th.D. dissertation, New orleans Baptist Theological Seminary, 1990.

Kibble, David G. "The Kingdom of God and Christian Politics." Themelios 7 (September 1981): 24-32.

Kik, J. Marcellus. Church and State. New York: Thomas Nelson, 1963.

Killeckey, Edward R. "The Medellin Guidelines." African Ecclesiastical Review 13 (1971): 25-32.

Kirk, J. Andrew. "Liberation Theology in Latin America Today." The Modern Churchman 23 (1980): 161-71.

Theology Encounters Revolution. Downers Grove, IL: InterVarsity, 1980 .

Klaiber, Jeffrey. The Catholic Church in Peru, 18211985. Washington, DC: Catholic University of America Press, 1992.

Knapp, Stephen. "A Preliminary Dialogue with Gutiérrez' A Theology of Liberation." In Evangelicals and Liberation, ed. Carl E. Armerding, 10-42. Phillipsburg, NJ: Presbyterian and Reformed Publishing Co.. 1979.

Kolden, Marc. "On Speaking of the Kingdom Today." Word \& World $2(1982): 150-60$.

Kümmel, Werner G. Promise and Fulfillment: The Eschatological Message of Jesus. Translated by Dorothea M. Barton. Naperville, IL: A. R. Allenson, 1957. 
Küng, Hans. The Church. Translated by Ray and Rosaleen Ockenden. New York: Sheed \& Ward, 1967.

Kuzmic, Peter. "The Church and the Kingdom of God: A Theological Reflection." In The Church: God's Agent for Change, ed. Bruce J. Nicholls, 49-81. Exeter: Paternoster Press, 1986.

Ladd, George. Crucial Questions About the Kingdom of God. Grand Rapids, MI: Eerdmans, 1952.

The Gospel of the Kingdom. Grand Rapids, MI: Eerdmans, 1959.

A Theology of the New Testament. Grand Rapids, MI: Eerdmans, 1974.

Ladner, Gerhart B. The Idea of Reform. Cambridge, MA: Harvard University Press, 1959.

Landázuri Ricketts, Juan. "Inaugural Address." In The Church in the Present-Day Transformation of Latin America in the light of the Council: Position Papers, ed. Catholic Church, Consejo Episcopal Latinoamericano. Washington, DC: U.S.C.C., 1973.

Leith, John. John Calvin's Doctrine of the Christian Life. Louisville, KY: Westminster; John Knox Press, 1989.

Lambert, Bernard. Ecumenism: Theology and History. Translated by Lancelot C. Sheppard. New York: Herder and Herder, 1967.

Latourelle, René. "Vatican II." Dictionary of Fundamental Theology. Edited by René Latourelle and Rino Fisichella. New York: Crossroad, 1994.

le Guillou, Marie-Joseph. "Ecclesiology." Encyclopedia of Theology: The Concise Sacramentum Mundi. Edited by Karl Rahner. New York: Crossroad, 1991.

Lee, Martin A., and Pia Gallegos. "Gustavo Gutierrez: With the Poor." Christianity and Crisis 47 $(1987)$ : $113-15$. 
Lindström, Gösta. The Kingdom of God in the Teaching of Jesus. Edinburgh: Oliver and Boyd, 1963.

Linnan, John. "Dogmatic Constitution on the Church, Lumen Gentium and Decree on the Pastoral Office of the Bishops in the Church, Christus Dominus." In Vatican II and Its Documents, ed. Timothy $E$. O'Connell, 39-61. Wilmington, DE: Michael Glazier, 1986.

Lord, Elizabeth. "Human History and the Kingdom of God: Past Perspectives and Those of $\mathrm{J}$. I. Segundo." Heythrop Journal 30 (1989): 293-305.

Lohfink, Gerhard. "The Exegetical Predicament Concerning Jesus' Kingdom of God Proclamation." Theology Digest 36 (1989): 103-10.

Lohfink, Norbert. "Religious Orders: God's Therapy for the Church." Theology Digest 33 (1986): 203-12.

Lopetegui, León, and Félix Zubillaga. Historia de la Iglesia en la América Española, desde el descubrimiento hasta comienzos del Siglo XIX. Madrid: Editorial Católica, 1965.

López-Trujillo, Alfonso. De Medelín a Puebla. Madrid: Biblioteca de Autores Cristianos, 1980.

Löwith, Karl. Meaning in History. Chicago: University of Chicago Press, 1949.

Luther, Martin. "An Open Letter on the Harsh Book Against the Peasants." In Luther's Works, ed. Robert Schultz, trans. Charles M. Jacobs, 46: 6385. Saint Louis, MO: Concordia Publishing House; Philadelphia, PA: Fortress Press, 1958-1986.

Mackay, John A. The Other Spanish Christ. New York: Macmillan, 1932.

Maggiolini, Allesandro. "The Magisterial Teaching on Experience in the Twentieth Century: From the Modernist Crisis to the Second Vatican Council." Communio International Catholic Review 23 (1996): $225-43$. 
Manzanera, Miguel. Teología, salvación y liberación en la obra de Gustavo Gutiérrez. Bilbao, Spain: Ediciones Mensajero, 1978.

Mariátegui, José Carlos. Seven Interpretative Essays on Peruvian Reality. Translated by Marjory Urquidi. Austin: Uriversity of Texas Press, 1971.

Marrou, Henri. Saint Augustine and His Influence through the Ages. New York: Harper Torchbooks, 1957 .

Marsh, W. H. The New Testament Church. Philadelphia: American Baptist Publication Society, 1898.

Marx, Karl. Communist Manifesto. With an Introduction by Stefan Possony. Chicago: Henry Regnery Co.. 1954 .

Mascal, E. L. Corpus Christi. London: Longmans, Green and Co., 1953.

Mateo Seco, Lucas G. G. Gutiérrez, H. Assmann, R. Alves: teología de la liberación. Madrid, Spain: Editorial Magisterio Español, S.A., 1981.

McBrien, Richard P. Catholicism: Study Edition. Minneapolis: Winston Press, 1981.

Church: The Continuing Quest. New York: Newman Press, 1970.

The Church in the Thought of the Bishop John Robinson. Philadelphia: Westminster, 1966.

The Remaking of the Church. New York: Harper \& Row, 1973.

McCann, Dennis. Christian Realism and Liberation Theology. Maryknoll, NY: Orbis, 1981.

McCarthy, Timothy G. The Catholic Tradition: Before and After Vatican II 1878-1993. Chicago: Loyola University Press, 1994.

McCue, James I. "A Roman Catholic Perspective." Dialog 5 (1966): 176-81. 
McClain, Alva J. The Greatness of the Kingdom. Grand Rapids, MI: Zondervan, 1959.

McGovern, Arthur F. Liberation Theology and Its Critics. Maryknoll, NY: Orbis, 1989.

McGrath, Marcos. "The Impact of Gaudium et Spes: Medelín, Puebla, and Pastoral Creativity." In The Church and Culture since Vatican II, ed. Joseph Gremilizon, 61-73. Notre Dame, IN : University of Notre Dame Press, 1985.

"The Puebla Final Document: Introduction and Commentary." In Puebla and Beyond, ed. John Eagleson and Philip Scharper, 87-110. Maryknoll, NY: Orbis, 1979.

McGrath, Mark. "Church Doctrine in Latin America After the Council." In The Church and Social Change in Latin America, ed. Henry A. Landsberger, 97-112. Notre Dame, IN: University of Notre Dame Press, 1970 .

McNamara, Kevin. "The Mystery of the Church." In Vatican II: The Constitution on the Church; $A$ Theological and Pastoral Commentary, ed. Kevin McNamara, 75-102. Chicago, IL: Franciscan Herald Press, 1968.

"Recent Trends and Developments in the Catholic Church." Mid-Stream 18 (1979): 345-57.

Mechan, J. Iloyd. Church and State in Latin America. Durham, NC: University of North Carolina Press, 1966 .

Medhurst, Kenneth. "Peru." In Religion in Politics: A World Guide, ed. Stuart Mews, 214-15. London: St. James Press, 1989.

Metz, Johannes B. Theology of the World. Translated by William Glen-Doepel. New York: Herder and Herder, 1969.

Míguez-Bonino, José. Doing Theology in a Revolutionary Situation. Philadelphia: Fortress Press, 1975. 
Miguélez, Xosé. La teología de la liberación y su método. Barcelona: Herder, 1976.

Miller, J. Michael, ed. The Encyclicals of John Paul II. Huntington, IN: Our Sunday Visitor, 1996.

Miller, Vincent. "de Lubac, Henry." The HarperCollins Encyclopedia of Catholicism. 1995.

Moltmann, Jürgen. Theology of Hope: On the Ground and Implications of a Christian Eschatology. New York: Harper \& Row, 1967.

Church in the Power of the Spirit [New York: Harper \& Row, 1977.

Morrison, Karl F. "Rome and the City of God." Transactions of the American Philosophical Society 54, Part $1(1964):$ 1-55.

"Introduction." In Imperial Lives and Letters of the Eleventh Century, ed. Robert Benson, trans. Theodor E. Mommsen and Karl F. Morrison, 3-51. New York/London: Columbia University Press, 1962.

Morrison, Karl F., ed. The Investiture Controversy. New York: Holt, Rinehart and Winston, 1971.

Mottesi, Osvaldo Luis. "An Historically Mediated 'Pastoral' of Liberation: Gustavo Gutierrez's Pilgrimage Towards Socialism." Ph.D. dissertation, Emory University, 1985.

Murphy, Francis X., and Gary MacEoin. Synod 167: A New Sound in Rome. Milwaukee, WI: Bruce Publishing Co. . 1968 .

National Conference of Catholic Bishops Secretariat. The Church in the Present-Day Transformation of Latin America in the Light of the Council: Conclusiones. Washington, DC: USCC, 1973.

Puebla: Evangelization at Present and in the Future of Latin America: Conclusions. Washington, DC: USCC, 1979. 
Naugle, David K., Jr. "A Theological Analysis and Evaluation of the Realized Eschatology of C. H. Dodd." Th.D. dissertation, Dallas Theological Seminary, 1987.

Nessan, Craig L. Orthopraxis or Heresy. Atlanta, GA: Scholars Press, 1989.

Neufeld, Karl H. "In the Service of the Council: Bishops and Theologians at the Second Vatican Council." In Vatican II: Assessment and Perspective, ed. Rene Latourelle, 1:74-105. Mahwah, NJ: Paulist Press, 1988.

Neuhaus, Richard John. "Liberation Theology and the Captivities of Jesus." In Mission Trends $N^{\circ} 3$. Third World Theologies, ed. Gerald H. Anderson and Thomas F. Stransky, 41-61. New York: Paulist, 1976 .

Nichols, Aidan. From Newman to Congar. Edinburgh: T. \& T. Clark, 1990.

The Shape of Catholic Theology. Edinburgh: T. \& T. Clark, 1991.

Nickoloff, James B. "The Church and Human Liberation: The Ecclesiology of Gustavo Gutierrez." Ph.D. dissertation, Graduate Theological Union, 1989.

Nida, Eugene A. "Christo-Paganism." Practical Anthropology 8 (1961): 1-15.

Núñez, Emilio A. Liberation Theology. Translated by Paul E. Sywulka. Chicago: Moody Press, 1985.

Nuñez, Emilio, and William D. Taylor. Crisis in Latin America: An Evangelical Perspective. Chicago: Moody Press, 1989.

O'Brien, David J., and Thomas Shannon. Catholic Social Thought: The Documentary Heritage. Maryknoll, NY: Orbis, 1992.

Oliveros, Roberto. Liberación y teología; génesis y crecimiento de una reflexión (1966-1976). Lima, Perú: Centro de Estudios y Publicaciones, 1980. 
O'Meara, Thomas. "Congar, Yves." The HarperCollins Encyclopedia of Catholicism. 1995.

- "Raid on the Dominicans': The Repression of 1954." America 170 (February 5, 1994): 8-16.

Orr, James. The Ritschlian Theology and the Evangelical Faith. 2 d ed. New York: Thomas Whittaker, 1898 .

Ott, Ludwig. Fundamentals of Catholic Dogma. Translated by Patrick Iynch. Cork, Ireland: Mercier Press, 1957.

The Oxford Dictionary of Christian Church. Edited by F. L. Cross, and E. A. Livingston. $2 d$ ed. New York: Oxford University Press, 1983. S.V. "Teilhard de Chardin, Pierre."

Pannenberg, Wolfhart. Theology and the Kingdom of God. Philadelphia: Westminster Press, 1969.

Pantelís, Jorge. "Reino de Dios e Iglesia en el proceso histórico de la liberación." Ph.D. dissertation, Union Theological Seminary, 1975.

Papal Teacinings: The Church. Selected and arranged by the Benedictine Monks of Solesmes, translated by E. O'Gorman. Boston, MA: St. Paul Editions, 1962.

Paul VI. "Popuiorum progressio." In The Papal Encyclicals, compiled by Claudia Carlen, 5:183201. Wilmington, NC: McGrath Pub. Co., 1990.

The Teachings of Pope Paul VI-1971. Vatican City: Libreria Editrice Vaticana, 1972.

Pernia, Antonio. "The Kingdom of God in the Liberation Theology of G. Gutierrez, L. Boff, and J. L. Segundo." Th.D. dissertation, Pontificia Universitas Gregoriana (Vatican), 1988. Published as God's Kingdom and Human Liberation. Manila, Philippines: Divine word Publications, 1990.

Perrin, Norman. Jesus and the Language of the Kingdom. Philadelphia: Fortress, 1976.

The Kingdom of God in the Teaching of Jesus. Philacelphia: Westminster, 1963. 
Rediscovering the Teachings of Jesus. New York: Harper \& Row, 1967.

Philips, Gérard. "Dogmatic Constitution on the Church: History of the Constitution." In Commentary on the Documents of Vatican II, ed. Herbert Vorgrimler, 1:105-137. New York: Herder and Herder, 1967.

Phillips, Steven. "The Use of Scripture in Liberation Theologies: An Examination of Juan Luis Segundo, James H. Cone, and Jürgen Moltmann." Ph.D. dissertation, The Southern Baptist Theological Seminary, 1978 .

Pinnock, Clark H. "Liberation Theology: The Gains, the Gaps." Christianity Today (January 16, 1976): 13-15.

Pius XI. The Kinship of Christ, Encyclical Letter: "Quas Primas." Prepared with analytical outlines, questions, scriptural references and bibliography by Gerald $C$. Treacy. New York: America Press, 1944.

Planas, Ricardo. Liberation Theology: The Political Expression of Religion. Kansas City, MO: Sheed \& Ward, 1986.

Prien, Hans-Jürgen. La historia del cristianismo en América Latina. Salamanca, España: Sigueme, 1985.

Principe, walter. "Chenu, M.-D." The HarperCollins Encyclopedia of Catholicism. 1995.

Rahner, Karl. Theological Investigations. Vol. 5. Translated by Karl-H. Kruger et al. Baltimore: Helicon Press, 1966.

Rahner, Karl, and Herbert Vorgrimler. "Kingdom of God." Concise Theological Dictionary, ed. Karl Rahner and Herbert Vorgrimler. $2 \mathrm{~d}$ ed. London: Burns \& Oates, 1983.

Rahner, Karl, and wilhelm Thüsing. A New Christology. Translated by David Smith and Verdant Green. New York: Seabury Press, 1980.

Ramsay, William M. Four Modern Prophets. Atlanta: John Knox Press, 1986. 
Randall, John Herman. "The Manifold Experience of Augustine." The American Scholar 38 (Winter 1968/69): $127-34$.

Ratzinger, Joseph. Eschatology: Death and Eternal Life. Translated by Michael Waldstein. Washington, DC: Catholic University of America Press, 1988 .

Rausch, Thomas P. Catholicism at the Dawn of the Third Millenium. Collegeville, MN: Liturgical Press, 1996.

Rauschenbusch, Walter. A Gospel for the social Awakening. Selections from the Writings of Walter Rauschenbusch. Compiled by Benjamin $E$. Mays and an introduction by $C$. Howard Hopkins. New York: Association Press, 1950.

A Theology for the Social order. Nashville: Abingdon Press, 1961.

Ridderbos, Herman. The Coming of the Kingdom. Translated by $\mathrm{H}$. de Jongste. Philadelphia, PA: Presbyterian and Reformed Pub., 1962.

Riga, Peter. The Church Renewed. New York: Sheed and Ward, 1966.

"The Ecclesiology of Johann Adam Möhler." Theological Studies 22 (1961) : 563-87.

Rikhof, Herwi. The Concept of Church. London: Sheed and Ward, 1981 .

Ritschl, Albrecht. The Christian Doctrine of Justification and Reconciliation, ed. H. R. Mackintosh and A. B. Macaulay. Clifton, NJ: Reference Book Publisher, 1966.

Three Essays. Translated by Philip Hefner. Philadelphia: Fortress, 1972.

Robertson, Archibald. Regnum Dei. New York: Macmillan, 1901. 
Rodor, Amin A. "The Concept of the Poor in the Context of the Ecclesiology of Liberation Theology." $\mathrm{Ph} . \mathrm{D}$. dissertation, Andrews University, 1986.

Rowland, Christopher. "Reflections on the Politics of the Gospel." In The Kingdom of God and Human Society, ed. Robin Barbour, 224-41. Edinburgh: $T$. \& T. Clark, 1993.

Ruiz, Octavio. "La teología de la liberación y su método." Medelín 14 (March 1988): 41-64.

Rycroft, w. Stanley, ed. Indians of the High Andes. New York: Committee on Cooperation in Latin America, 1946.

Religion and Faith in Latin America. Philadelphia: Westminster, 1958.

Sahlberg, Carl-Erik. "Augustine--The African Who Influenced Europe." Africa Theological Journal 21 (1992): $112-17$.

Santagada, Osvaldo D. Review of Teología de la Liberación: Perspectivas, by G. Gutiérrez. Cuadernos of Teología 3 (1973): 96-98.

Schaff, David S. "Cardinal Bellarmine--Now Saint and Doctor of the Church." Church History 2 (1933): $41-55$.

Schall, James V. "The American Press Views Puebla." In The Pope and Revolution, ed. Quentin L. Quade, 86-96. Washington, DC: Ethics and Public Policy Center, 1982 .

Schillebeeckx, Edward. "Liberation Theology between Medelin and Puebla." Theology Digest 28 (Spring 1980): $3-7$.

The Mission of the Church. Translated by $\mathrm{N}$. D. Smith. New York: Seabury Press, 1973.

Schlinder, David I. "Cardinal Henri de Lubac." Communio International Catholic Review 18 (1991): 296. 
Schnackenburg, Rudolf. God's Rule and Kingdom. Translated by John Murray. New York: Herder and Herder, 1963 .

Schoof, T. Mark. A Survey of Catholic Theology 18001970. Translated by N. D. Smith. New York:

Paulist Newman Press, 1970.

Schuck, Michael J. The Mission of the Church. Translated by N. D. Smith. New York: Seabury Press, 1973.

Schweitzer, Albert. The Mystery of the Kingdom of God. Translated by Walter Lowrie. New York: MacMillan. 1950 .

Scott, Ernest F. The Kingdom of God in the New Testament. New York: MacMillan, 1931.

Segundo, Juan Luis. "Capitalism-Socialism: A Theological Crux." In The Mystical and Political Dimension of the Christian Faith, ed. Claude Geffré and Gustavo Gutiérrez, 105-23. New York: Herder and Herder, 1974.

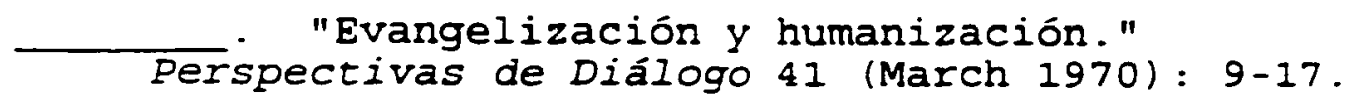
Grace and the Human Condition. Translated
by John Drury. Maryknoll, NY: Orbis, 1973. - The Historical Jesus of the Synoptics. Translated by John Drury. Maryknoll, NY: Orbis, 1985 . - The Liberation of Theology. Translated by John Drury. Maryknoll, NY: Orbis, 1976.

Sharpe, Eric J. "The Kingdom of God." A New Dictionary of Christian Theology. Edited by Alan Richardson and John Bowden, 317-18. London: SCM Press, 1989.

Skydsgaard, Kristen E. "The Church as Mystery and as People of God." In Dialogue on the Way, ed. George L. Lindbeck, 145-74. Minneapolis: Augsburg, 1965. 
"Kingdom of God and Church." Scottish

Journal of Theology 4 (1951): 383-97.

Smith, Brian $\mathrm{H}$. The Church and Politics in Chile. Princeton, NJ: Princeton University Press, 1982.

Snyder, Howard A. Models of the Kingdom. Nashville: Abingdon, 1991.

Sobrino, Jon. "Central position of the Reign of God in Liberation Theology." In Magisterium

Liberationis: Fundamental Concepts of Liberation Theology, ed. Ignacio Ellacuría and Jon sobrino, 350-88. Maryknoll, NY: Orbis, 1993. - Christology at the Crossroads. Translated by John Drury. Maryknoll, NY: Orbis, 1978.

"El Conocimiento Teológico en la Teología Europea y Latinoamericana." Estudios Centroamericanos 30 (1975): 426-45.

Sölle, Dorothee. "Resistance: Toward a First World Theology." Christianity and Crisis 39 (1979): $178-82$.

Sparrow-Simpson, William J. The Catholic Conception of the Church. London: Robert Scott, 1914.

Spinella, Joseph D. "An Evaluation of the Theology of Liberation as Presented by Gustavo Gutierrez." Th.D. dissertation, Dallas Theological Seminary, 1981 .

Staehelin, Ernst. Die Verkündigung des Reiches Gottes in der Kirche Jesu Christi. 7 vols. Basel: F. Reinhardt, 1951-65.

Stein, Robert H. The Method and Message of Jesus' Teachings. Philadelphia, PA: Westminster, 1978.

Stogre, Michael. "Commentary on the Pastoral Constitution on the Church in the Modern world." In The Church Renewed, ed. George P. Schner, 1936. Lanham, MD: University Press of America, 1986 . 
Stroup, Herbert. Church and State in Confrontation. New York: Seabury Press, 1967.

Subilia, Vittorio. "The Ecclesiology of Vatican II." The Reformed and Presbyterian World 28 (1965): 200-210.

Traboulay, David $M$. "The Church and the University in Colonial Latin America." Zeitschrift für Missionswissenschaf und Religionswissenschaft 63 (1979): 283-94.

Valcárcel, Luis E. Ruta cultural del Perú. [Mexico City], Mexico: Fondo de Cultura Económica, 1945.

Van Beeck, Frans J. Catholic Identity After Vatican II. Chicago: Loyola University Press, 1985.

Vinson, William E. "The Kingdom of God according to Thomas Aquinas." Ph.D. dissertation, Southwestern Baptist Theological Seminary, 1987.

Viviano, Benedict. The Kingdom of God in History. Wilmington, DE: Michael Glazier, 1988.

Vorgrimler, Herbert. "Karl Rahner: The Theologian's Contribution." In Vatican II Revisited, ed. Alberic Stacpoole, 37-42. Minneapolis, MN: Winston Press, 1986.

Walker, Williston. A History of the Christian Church. New York: Scribner, 1949.

Walpole, G. H. S. The Kingdom of Heaven. New York: E. P. Dutton, 1909 .

Wand, John W. C. The Mystery of the Kingdom of God. London: Faith press, 1953.

Weckmann, Luis. "The Middle Ages in the Conquest of America." In History of Latin American

Civilization, ed. Lewis Hanke, 1:10-22. Boston: Little, Brown and Co., 1967.

Weiss, Johannes. Jesus' Proclamation of the Kingdom of God. Edited and translated by R. H. Hiers and D. L. Holland. Philadelphia: Fortress, 1971. 
Welch, Jerome A. Catholicism Today. Fort Wayne, IN: Jewel, 1977.

Wicks, Jared. "Council of Trent." Dictionary of Fundamental Theology. Edited by René Latourelle, 1126-29. New York: St. Pauls, 1994.

Willey, David. God's Politician. London: Faber and Faber, 1992.

Williams, Daniel D. "The Significance of st. Augustine Today." In A Companion to the study of $S t$. Augustine, ed. Roy W. Battenhouse, 3-14. New York: Oxford University Press, 1955.

Williams, George H. "Christology and Church-State Relations in the Fourth Century, Pt. 1." Church History 20 (September 1951): 3-33.

"Christology and Church-State Relations in
the Fourth Century, Pt. 2." Church History 20 (December 1951): 3-26.

Wilson, Richard F. "Human Liberation and Theology: An Examination of the Theology of Gustavo Gutierrez, James $\mathrm{J}$. Cone, and Mary Daly." Ph.D. dissertation, Southern Baptist Theological Seminary, 1982 .

Wisloff, Carl F. "Recent Trends in Roman Catholicism." Themelios 10 (April 1985): 10-15.

Wittstadt, Klaus. "On the Eve of the Second Vatican Council (July 1--October 10, 1962)." In History of Vatican II, ed. Giuseppe Alberigo and Joseph A. Komonchak, 1:405-500. Maryknoll, NY: Orbis, 1995.

Wood, Susan. "The Nature-Grace Problematic Within Henri de Lubac's Christological Paradox." Communio International Catholic Review I9 (1992): $389-403$. 